JULIANA RUSSO ANTUNES

O cuidado de mulheres em um serviço de Atenção Básica: problematização de uma experiência de trabalho interprofissional

São Paulo

2018 


\section{JULIANA RUSSO ANTUNES}

O cuidado de mulheres em um serviço de Atenção Básica: problematização de uma experiência de trabalho interprofissional

\section{Versão Original}

Dissertação apresentada à Faculdade de Odontologia da Universidade de São Paulo, Programa Mestrado Profissional Interunidades de Formação Interdisciplinar em Saúde para a obtenção do título de Mestre em Ciências da Saúde.

Orientadora: Profa. Dra. Fátima Corrêa Oliver 
Autorizo a reprodução e divulgação total ou parcial deste trabalho, por qualquer meio convencional ou eletrônico, para fins de estudo e pesquisa, desde que citada a fonte.

Catalogação-na-Publicação

Serviço de Documentação Odontológica

Faculdade de Odontologia da Universidade de São Paulo

Antunes, Juliana Russo.

O cuidado de mulheres em um serviço de Atenção Básica: problematização de uma experiência de trabalho interprofissional / Juliana Russo Antunes ; orientador Fátima Corrêa Oliver -- São Paulo, 2018.

144 p. : fig., tab.; $30 \mathrm{~cm}$.

Dissertação (Mestrado Profissional) -- Programa de Pós-Graduação Interunidades em Formação Interdisciplinar em Ciências da Saúde. -Faculdade de Odontologia da Universidade de São Paulo.

Versão original

1. Atenção primária à saúde. 2. Mulheres. 3. Gênero e saúde. 4. Dispositivo grupal. I. Oliver, Fátima Corrêa. II. Título. 
Antunes JR. O cuidado de mulheres em um serviço da Atenção Básica: problematização de uma experiência de trabalho interprofissional. Dissertação apresentada à Faculdade de Odontologia da Universidade de São Paulo, Programa Mestrado Profissional Interunidades de Formação Interdisciplinar em Saúde, para a obtenção do título de Mestre em Ciências da Saúde.

Aprovado em: $/ 2018$

\section{Banca Examinadora}

Prof. Dr.

Instituição:

Julgamento:

Prof. Dr.

Instituição:

Julgamento:

Prof. Dr.

Instituição: Julgamento: 
Às mulheres de antes, de agora e de depois Às mulheres que parem e que trabalham Às preguiçosas Às mulheres que riem e que choram Às mulheres que lutam Às mulheres que gozam Às mulheres bruxas Às Marias Às quem queimam Às quem idolatram Às mulheres que fui Às mulheres que sou Às mulheres que serei Àquelas que a querem ser Àquelas que sempre a foram Àqueles que as queimam, as idolatram, as moldam, as adoecem - as fortalecem. (Juliana Russo) 


\section{AGRADECIMENTOS}

Para não fugir ao clichê: como agradecer e não esquecer de ninguém? Agradecendo a todas as pessoas que passaram por minha vida? Sim, pois todas; todas as pessoas constroem e moldam cotidianamente, o que sou, o que somos, o que é o nosso sexo, o que é o nosso corpo, e o que virá a ser.

Como fazer caber em palavras, tamanha descoberta existencial? Como denotar toda angústia e ansiedade? Como aparentar toda insegurança, respeito e gratidão?

Em todas as formas, potencializando-me ou dificultando a minha travessia, tudo deu forma ao que sou, neste momento, neste ato - pesquisa, até mesmo as noites mal dormidas, as pequenas vitórias, mas principalmente, quero celebrar os encontros - é tanta gratidão pela generosidade dos encontros. Encontros que tive quando nasci filha, neta e sobrinha, quando nasci irmã, quando nasci aluna, dançarina, quando nasci amiga, quando nasci inimiga, encontros que tive ao me apaixonar, ao odiar, ao me casar, encontros repentinos, forasteiros, encontros eternos, de reencontro. Encontro com o feminino e o feminismo, desencontro... turbilhão, pouso, onda, calmaria.

Agradeço cada pessoa que cruzou o meu caminho e nele imprimiu suas pegadas de caminhada lado a lado, antes de mim para me orientar ou para me direcionar onde eu não queria ir, pisando sobre as minhas pegadas para segui-las ou apagá-las, guiando minhas pegadas por rodopios e saltos, pegadas sorrateiras, pegadas arqueológicas.

Agradeço essencialmente àqueles encontros de porto seguro: aos meus pais pelo meu primeiro lugar no mundo, filha; ao meu irmão, cuja existência me tornou feminista, e ao meu companheiro, por nossa relação âncora/bote salva-vidas. Portos seguros são incentivos, colo, broncas e afetos!

Agradeço à orientadora desta pequisa, e ao programa MP; à minha equipe de trabalho, NASF, à coordenadora e à gerente da UBS; ao Ateliê de Terapia Ocupacional; ao núcleo duro da TO 37! Agradeço aos amigos que me ajudaram a começar minha trilha pelos estudos de gênero; às feministas.

Agradeço cada trabalhadora e trabalhador que me confiou suas palavras, minhas parceiras da coordenação do Grupo de Mulheres e cada mulher participante, àquelas que me cederam entrevistas, especialmente. Ah, mulheres! Neste nosso encontro em que tenho a maioria dos privilégios interseccionados, a maior presenteada, sou eu!

Agradeço a mim mesma pela realização deste trabalho!

Gratidão! 


\section{RESUMO}

Antunes JR. O cuidado de mulheres em um serviço de Atenção Básica: problematização de uma experiência de trabalho interprofissional [dissertação de mestrado profissional]. São Paulo: Universidade de São Paulo, Faculdade de Odontologia; 2018. Versão Original.

Este trabalho se propõe a discutir as práticas de cuidado a mulheres em um serviço de Atenção Básica, a partir da experiência da pesquisadora como terapeuta ocupacional de um Núcleo de Apoio à Saúde da Família (NASF). No cotidiano do trabalho compartilhado com a Estratégia de Saúde da Família (ESF), percebe-se que a Atenção à Saúde da Mulher abarca principalmente questões relacionadas à reprodução e situações específicas do ciclo fértil feminino. A partir das discussões de gênero, saúde e produção de cuidado integral e ampliado, foi possível discutir e sistematizar uma experiência grupal e interprofissional de cuidado a mulheres realizada em uma Unidade Básica de Saúde (UBS), da cidade de São Paulo. Além disso, houve também oportunidade de identificar e problematizar as estratégias de cuidado em resposta às necessidades de saúde das mulheres da área de abrangência desse serviço, de maneira a contribuir para a ampliação do cuidado na atenção primária em saúde. Para tal, foi realizada uma pesquisa de abordagem qualitativa com metodologia de estudo de caso, a partir da realização de trabalho de campo com observação participante e 17 entrevistas com os seguintes sujeitos: coordenadoras de NASF, trabalhadoras da ESF desta UBS, trabalhadoras de NASF que são coordenadoras do Grupo de Mulheres e mulheres participantes do referido grupo. A análise dos dados indicou as seguintes categorias: gênero como potencial de desgaste e de fortalecimento; escuta reconhecida pelas trabalhadoras como demanda das mulheres; empoderamento das mulheres como objetivo do Grupo de Mulheres; Grupo de Mulheres como estratégia de cuidado às necessidades ampliadas de saúde. Percebeu-se que as profissionais compreendem a Saúde da Mulher a partir de uma perspectiva integral. Por outro lado, a formação e os arranjos organizacionais e de gestão direcionam as práticas no sentido do modelo biomédico. E no caso da assistência às mulheres, as práticas são direcionadas aos protocolos de Saúde Reprodutiva, o que retrata as opressões de gênero. Neste território, a "sobrecarga" das mulheres, ou seja, as assimetrias de gênero, são fator de grande relevância em seus processos de adoecimento, nos quais a determinação social e as condições de vida aparecem como necessidades de saúde das mulheres ao serviço. As participantes do Grupo e as profissionais apontam a importância do Grupo de Mulheres para os processos de 
recuperação de saúde e de cidadania, porém, poucas mulheres são direcionadas a serem cuidadas neste dispositivo. Com o intuito de propor melhorias para a assistência às mulheres, considera-se a importância de novos arranjos do processo de trabalho e de formação de gênero no local de trabalho. Em uma perspectiva mais abrangente, há que se considerar também esta questão na luta pela reformulação das Políticas e das práticas de Saúde Pública. Assim, propusemos a sistematização do dispositivo "Grupo de Mulheres" como estratégia de cuidado e de emancipação, apresentada em um caderno anexo a esta dissertação.

Palavras-chave: Atenção primária em saúde, Mulheres, Gênero e saúde, Dispositivo grupal. 


\begin{abstract}
Antunes JR. Women's care in Primary Healthcare: the problematization of an interprofessional experience in practice [dissertation professional]. São Paulo: Universidade de São Paulo, Faculdade de Odontologia; 2018. Versão Original.
\end{abstract}

26486270

The purpose of this study is to discuss the practice of women's care within Primary Care (Atenção Básica) service, based upon this researcher's experience as an occupational therapist at a Family Healthcare Support Nuclei (Núcleo de Apoio à Saúde da Família - NASF). During routine daily work, in conjunction with the Family Healthcare Strategy (Estratégia de Saúde da Família - ESF), it can be perceived that the Attention to Women's Health target (Atenção à Saúde da Mulher) only covers issues related to reproduction and specific aspects of the female fertility cycle. It is considered that, from discussions of gender and health and the delivery of a broader integrated care, it is possible to present and discuss an interprofessional group experience for the care of women care, understaken at a Primary Healthcare Unit (Unidade Básica de Saúde - UBS) in the city of São Paulo and to also identify care strategies and understanding of the health needs of women within the scope of this service, in order to contribute to the expansion of care in primary healthcare. To achieve this, the proposal was a qualitative approach with a case study methodology, derived from conducting fieldwork with participant observation and 17 interviews with NASF coordinators, ESF professionals at the UBS 'A', NASF professionals who coordinate the Women's Group and female participants of the group. Data analysis indicated the following categories: gender as potential for attrition and strengthening; health workers understand that the demand of women is to be heard; empowerment of women as an objective of the Women's Group; Women's Group as a strategy of care for the expanded needs of health. It was noticed that the professionals understand the Women's Health from an integral perspective, however, the training and the organizational and management arrangements direct the practices towards the biomedical model, and also, in the case of the assistance to the women, the protocols reproductive health, portraying gender oppression. In this territory, women's "overload", that is, gender asymmetries, are a major factor in their disease processes, where social determination and living conditions appear as health needs of women in health service. Women and professionals point out the importance of the Women's Group for health and 
citizenship recovery processes, however, few women are directed to being cared for in this device. With the purpose of proposing improvements to the care of women, the importance of new work process arrangements, gender training in the workplace, and the struggle for the reformulation of Public Health Policies and practices are considered. Thus, we proposed the systematization of the device "Women's Group" as a strategy of care and emancipation, presented in a notebook attached to this dissertation.

Keywords: Primary Care, Women, Gender and health, Group device 


\section{LISTA DE ILUSTRAÇÕES}

Figura 3.1 Infográfico da Brasilândia - Dados Sociodemográficos....................45

Quadro 3.2 Linha do tempo de desenvolvimento da RAS FÓ/Bras. de 1980 a $2011 \ldots . . .49$

Quadro 3.3 Composição da rede de serviços de saúde do território FÓ/Bras. em 2018 ....50

Figura 3.4 Mapa das Unidades de Saúde do território da FÓ/Bras.....................51

Figura 3.5 Linha do tempo do desenvolvimento da UBS A"

Tabela 3.6 Número de equipes de ESF apoiadas pelos NASF do território da ............54 Brasilândia

Tabela 3.7 Número de equipes NASF necessárias no território da Brasilândia..............55 


\section{LISTA DE ABREVIATURAS E SIGLAS}

$\mathrm{AB}$

ACS

$\mathrm{AE}$

AMA

APD

BDTD

BVS

Caderno AB 27

Caderno AB 34

Caderno AB 39

CAPS AD

CAPS adulto

CAPS IJ

CECCO

CEO

CER

CR DST

CRST

EIP

Equipes SF

ESF

FÓ/Bras.

HDRHC

INAMPS

INS

LGBTT

MS

NASF

NIR
Atenção Básica

Agente Comunitária de Saúde

Ambulatório de Especialidades

Assistência Médica Ambulatorial

Programa Acompanhante Comunitário de Saúde da Pessoa com

Deficiência

Biblioteca Digital Brasileira de Teses e Dissertações

Biblioteca Virtual de Saúde

Caderno de Atenção Básica n²7 - Diretrizes do NASF

Caderno de Atenção Básica n³4 - Saúde Mental

Caderno de Atenção Básica n³9 (v.1) - NASF: Ferramentas para a

Gestão e o Trabalho Cotidiano

Centro de Atenção Psicossocial álcool e outras drogas

Centro de Atenção Psicossocial

Centro de Atenção Psicossocial infantojuvenil

Centro de Convivência e Cooperativa

Centro de Saúde Bucal

Centro Especializado de Reabilitação

Centro de Referência Doenças Sexualmente Transmissíveis/AIDS

Centro de Referência de Saúde do Trabalhador

Educação Interprofissional

Equipes de Saúde da Família

Estratégia de Saúde da Família

Território da Freguesia do Ó/Brasilândia

Rede Hora Certa

Instituto Nacional de Assistência Médica da Previdência Social

Índices de Necessidades em Saúde

Lésbicas, Gays, Bissexuais, Travestis e Transexuais

Ministério da Saúde

Núcleo de Apoio à Saúde da Família

Núcleo Integrado de Reabilitação 
ONG

OSS

PACS

PAISM

PAS

PIP

PNAISM

$\mathrm{PNH}$

PS

PSF

PST

PTS

QUALIS

RAS

Scielo

$\mathrm{SMS} / \mathrm{SP}$

STS

SUS

TO

UBS

UFSCar

UNIFESP

USP
Organização Não Governamental

Organização Social de Saúde

Programa de Agentes Comunitários de Saúde

Programa de Assistência Integral à Saúde da Mulher

Plano de Assistência à Saúde do Município de São Paulo

Prática Interprofissional

Política Nacional de Assistência Integral à Saúde da Mulher

Política Nacional de Humanização

Pronto-Socorro

Programa de Saúde da Família

Projeto de Saúde do Território

Projeto Terapêutico Singular

Projeto Qualidade Integral à Saúde

Rede de Assistência à Saúde

Scientific Eletronic Library Online

Secretaria Municipal de Saúde de São Paulo

Supervisão Técnica de Saúde

Sistema Único de Saúde

Terapeuta Ocupacional

Unidade Básica de Saúde

Universidade Federal de São Carlos

Universidade Federal de São Paulo

Universidade de São Paulo 


\section{SUMÁRIO}

1 INTRODUÇÃ

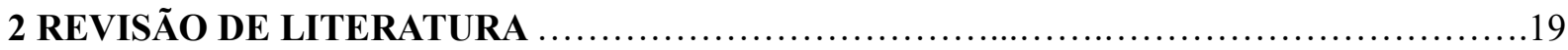

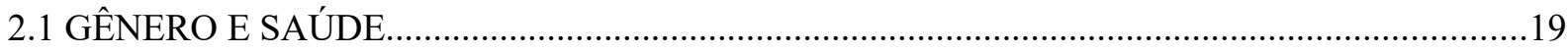

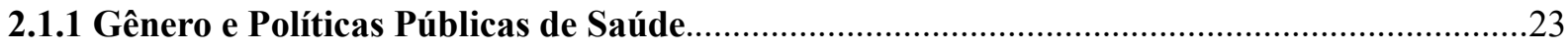

2.1.1.1 A Política Nacional de Assistência Integral à Saúde da Mulher (PNAISM).............................24

2.1.1.2 O Núcleo de Apoio à Saúde da Família (NASF)......................................................................25

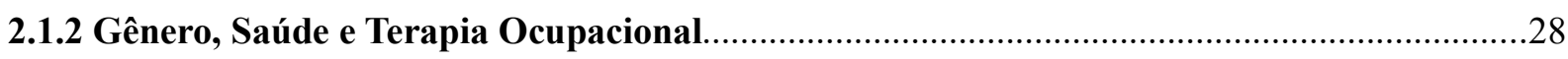

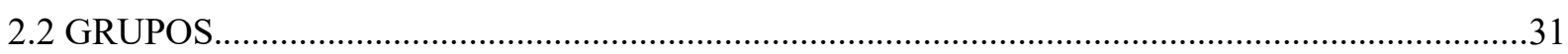

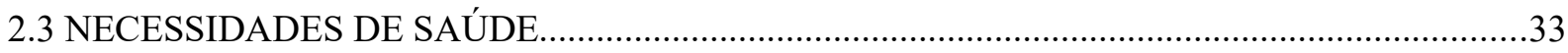

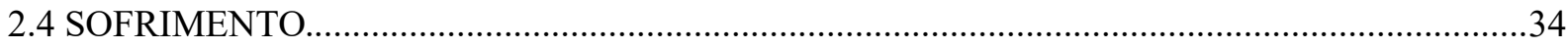

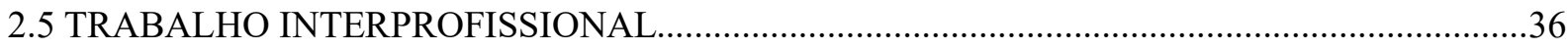

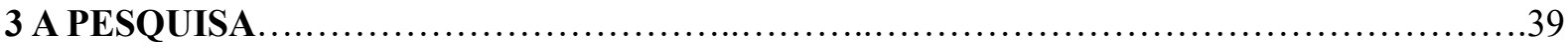

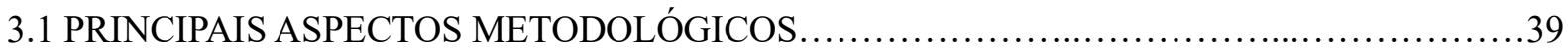

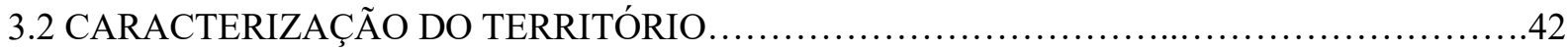

3.2.1 Histórico do território e alguns dados sociodemográficos .............................43

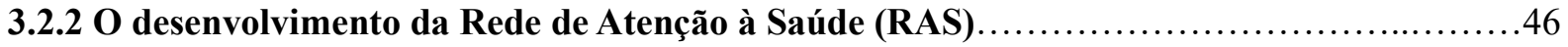

3.2.3 Composição da rede de serviços de saúde.........................................49

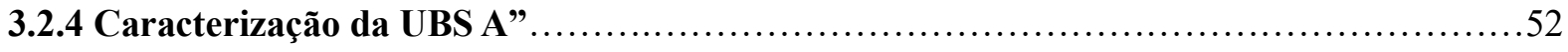

3.2.5 As equipes de Núcleos de Apoio à Saúde da Família do território (NASF)...................53

3.3 APRESENTAÇÃO E ANÁLISE DOS DADOS DO TRABALHO DE CAMPO........................56

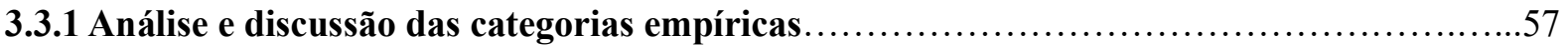

3.3.1.1 Gênero como potencial de desgaste e de fortalecimento................................58

3.3.1.2 Escuta reconhecida pelas trabalhadoras como demanda das mulheres......................62

3.3.1.3 Empoderamento das mulheres como objetivo do Grupo de Mulheres.......................64

3.3.1.4 Grupo de Mulheres como estratégia de cuidado às necessidades ampliadas de saúde..........66

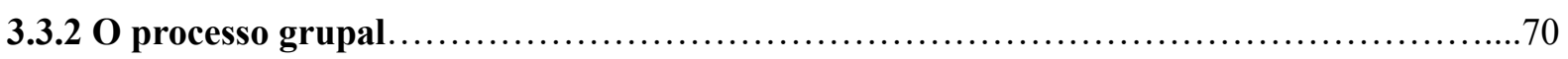

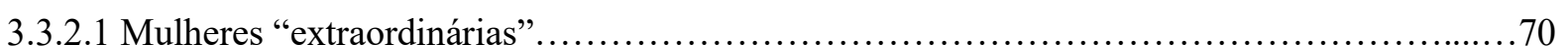

3.3.2.2 História do Grupo de Mulheres......................................................... 75

3.3.2.3 Sistematização do processo grupal..................................................... 77

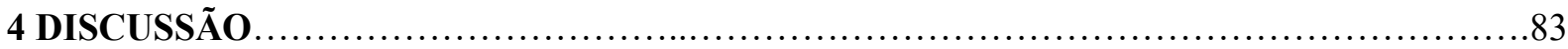

5 CONSIDERAÇÕ

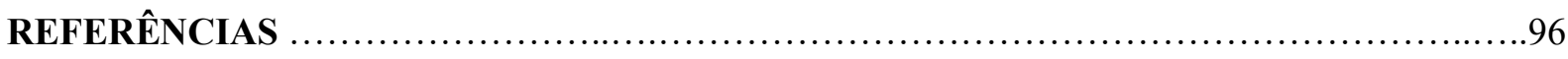

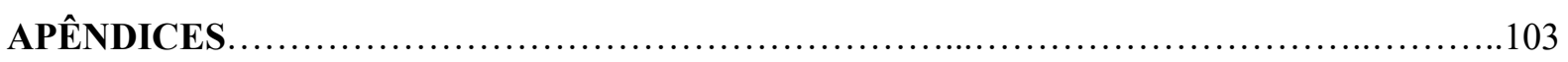

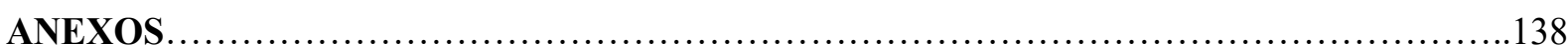




\section{INTRODUÇÃO}

No Brasil, a saúde da mulher foi incorporada às políticas nacionais de saúde nas primeiras décadas do século XX, sendo limitada, nesse período, às demandas relativas à gravidez e ao parto. Os programas materno-infantis, elaborados nas décadas de 30, 50 e 70, traduziam uma visão restrita sobre a mulher, baseada em sua especificidade biológica e no seu papel social de mãe e doméstica, responsável pela criação, pela educação e pelo cuidado com a saúde dos filhos e demais familiares (Brasil, 2004, p.15).

Este trabalho propõe-se a questionar as práticas de cuidado às mulheres em um serviço de Atenção Básica, a partir da experiência da pesquisadora como terapeuta ocupacional de um Núcleo de Apoio à Saúde da Família (NASF). Tendo como enfoque as discussões de gênero e saúde, além de produção de cuidado integral e ampliado, será apresentada e problematizada uma experiência grupal de cuidado às mulheres de uma Unidade Básica de Saúde da cidade de São Paulo.

No cotidiano do trabalho compartilhado com a Estratégia de Saúde da Família (ESF), percebe-se que a prática da Atenção à Saúde da Mulher prioriza apenas questões relacionadas à reprodução e situações específicas do ciclo fértil feminino, o que denota a tendência de medicalizar a saúde e o corpo. Em janeiro de 2008 foram propostos pela Portaria $n^{\circ} 154$ do Ministério da Saúde (MS), os Núcleos de Apoio à Saúde da Família (NASF). Os NASF têm o intuito de apoiar a inserção da ESF e ampliar a abrangência e a resolutividade da assistência em saúde, também no que se refere ao cuidado de mulheres. Esses núcleos são constituídos de equipes interdisciplinares que devem atuar em conjunto com as equipes da ESF, compartilhando e apoiando as práticas de saúde (Brasil, 2009, p.7).

A saúde da mulher é uma das áreas estratégicas de atuação do NASF. Sob a perspectiva de gênero, o NASF aborda temas específicos como "A saúde mental da população feminina" e a "Violência contra a mulher e violência intrafamiliar", em que se destaca o "Papel dos grupos" no manejo compartilhado destas situações de sofrimento (Brasil, 2009, p.8).

Um estudo sobre a demanda de equipes de ESF da periferia de São Paulo, aponta a prevalência de $24,58 \%$ de transtornos mentais comuns [como depressão e transtornos de ansiedade] sendo que os grupos mais vulneráveis são mulheres, idosos, pessoas com baixa escolaridade e menor renda per capita (Brasil, 2009, p.38). Muitas das mulheres do território 
de abrangência deste serviço têm diversos destes fatores interseccionados, aumentando o risco de adoecimentos nesta população.

Grande parte das "agendas" das profissionais do NASF, principalmente os núcleos mais conectados com a Saúde Mental (psicologia, terapia ocupacional e psiquiatria), fica direcionada a atendimentos individuais. Isso porque na relação de trabalho com a ESF, essas profissionais do NASF são majoritariamente abordadas para atendimentos a mulheres e suas manifestações de sofrimento (adoecimentos), comuns e severos. Os atendimentos às mulheres se dão nas mais variadas composições de profissionais: uma dupla de profissionais do NASF ou apenas uma profissional do NASF; parcerias com as profissionais da ESF como enfermeiras, médicas, Agentes Comunitárias de Saúde (ACS) ${ }^{1}$ e auxiliares de enfermagem. Os encontros podem ser de frequência mensal, quinzenal ou até mesmo pontuais para situações de acolhimento. São utilizados diversos recursos como conversas com familiares, articulação com outros serviços, entre outros. Enfim, composições de atendimentos às mulheres que exigem grande organização da equipe mas são direcionadas pontualmente a um sujeito.

Considerando esta demanda de cuidar de mulheres, a pesquisadora, sendo terapeuta ocupacional desta equipe de NASF (NASF A²) junto a psicóloga e uma das fisioterapeutas, propuseram em maio de 2014 a criação de um "Grupo de Saúde Mental” somente para mulheres. Logo no início, é proposto às mulheres que batizassem o grupo, que recebeu então o nome de "Grupo de Mulheres", pois elas não se sentiam à vontade com o termo "saúde mental" e a ideia de "loucura" a que este nome remetia. As próprias mulheres já nos indicavam que as questões que traziam eram muito mais amplas do que enxergávamos.

$\mathrm{Na}$ relação terapêutica com estas mulheres, sendo em consultas individuais ou no Grupo, foi se percebendo que suas experiências de sofrimento tinham relação com suas histórias, condições de vida, e ainda, com questões de gênero. Porém, ao sermos contatadas, as equipes de Saúde da Família (SF) pouco abordavam estas situações, focando a demanda apresentada pelas mulheres em remissão de sintomas.

\footnotetext{
${ }^{1}$ Considerando que a língua portuguesa é marcada por "assimetrias de gênero" (Lins et al., 2016, p.12), optamos por utilizar as palavras em gênero feminino respeitando o gênero da maioria dos sujeitos desta pesquisa e das pessoas trabalhadoras do campo da saúde; apenas uma pessoa entrevistada era do gênero masculino. O gênero das citações de textos e entrevistas será mantido conforme as autoras e os autores escreveram ou disseram.

2 Devido à necessidade de sigilo para a não estigmatização do serviço estudado, optou-se por não identificá-lo, uma vez que a sua divulgação também não é necessária para o alcance dos resultados. Assim, denominar-se-á a UBS locus da pesquisa como UBS A" e a equipe de NASF como NASF A.
} 
Concordamos com a colocação indicada sobre o NASF em um dos Cadernos de Atenção Básica, de que haveria "um componente de sofrimento subjetivo associado a toda e qualquer doença [...] será sempre importante e necessária a articulação da saúde mental com toda a rede de saúde e, sobretudo, com a Atenção Primária à Saúde" (Brasil, 2009, p.36). Porém, percebemos que as equipes de SF tratam as situações das mulheres de maneira muito restritiva e pouco eficaz, focada essencialmente em intervenções medicamentosas. A organização do modelo de assistência dos processos de trabalho e as formações das profissões de saúde dificultam que as profissionais da ESF avancem para além dos protocolos de saúde reprodutiva. O que muitas vezes leva a fazerem leituras medicalizantes dos sofrimentos apresentados pelas mulheres.

Assim, ficam questionamentos: qual o panorama das ofertas de cuidado direcionado às necessidades das mulheres neste serviço? Quais os limites e potencialidades destas estratégias? Como o Grupo de Mulheres responde às necessidades das mulheres? "Como olhar o nosso fazer [...] e refletir sobre ele, produzindo teorias, modelos, métodos e técnicas?" (Maximino; Liberman, 2015, p.18).

Submersa nestas inquietações, provocada pela necessidade de análise do Grupo de Mulheres e tomada pela experiência de trabalho com estas mulheres, este estudo é proposto. Pretende-se descrever e analisar a experiência de cuidado às mulheres numa UBS no âmbito da ESF em parceria com o NASF, sob o ponto de vista da integralidade do cuidado e as questões de gênero.

Desta maneira, poderemos contribuir para o desenvolvimento da assistência, no sentido da ampliação do cuidado às mulheres. Assim, apresentaremos uma problematização da experiência do Grupo de Mulheres na UBS A". Também buscaremos analisar em que medida este Grupo responde às necessidades de saúde apresentadas pelas mulheres e não somente às demandas das equipes de SF. Por fim, pretende-se contribuir para a discussão sobre estratégias de acompanhamento de mulheres na Atenção Básica produzindo, para além da reflexão crítica sobre o referido Grupo, o reconhecimento e a divulgação de uma sistematização de cuidado às mulheres na Atenção Básica.

Para isto, foi proposta uma pesquisa de abordagem qualitativa com metodologia de estudo de caso, em que foi realizada observação participante dos encontros do Grupo de Mulheres durante o ano de 2017 e respectivo registro em Diário de Campo. Também foram realizadas 17 entrevistas com coordenadoras de NASF, trabalhadoras da ESF desta UBS, 
trabalhadoras de NASF que coordenam o Grupo de Mulheres e mulheres participantes do referido Grupo.

Nessa dissertação estão registrados os processos e produtos deste estudo, que começa com levantamento e análise dos documentos oficiais e manuais sobre o NASF, seguidos do contato com a produção científica sobre gênero e intervenções grupais, tanto no campo da saúde quando no da Terapia Ocupacional. Na sequência, serão apresentados o campo de pesquisa, os principais aspectos metodológicos, os dados obtidos no trabalho de campo, além de sua análise e diálogo com a produção bibliográfica. E por fim, está apresentado o produto desenvolvido como parte do programa de Mestrado Profissional: um caderno com linguagem acessível, que organiza a metodologia do Grupo de Mulheres. Temos o intuito de que esse caderno seja veiculado amplamente na Rede de Atenção à Saúde (RAS) para fomentar novas experiências de Grupos de Mulheres. 


\section{REVISÃO DE LITERATURA}

Neste capítulo serão apresentados os conceitos teóricos norteadores deste estudo tais como: gênero e intervenções grupais, tanto no campo da saúde como no da Terapia Ocupacional; necessidades de saúde e sua leitura no campo da Saúde Coletiva e, ainda, a importância da Prática Interprofissional (PIP) para a assistência a estas necessidades.

\subsection{GÊNERO E SAÚDE}

A categoria "gênero" tem seu uso popularizado nas ciências sociais desde os anos de 1990, porém, já era usada desde os anos de 1970. E surgiu nos estudos acadêmicos sobre a condição feminina e a origem da desigualdade entre homens e mulheres, através de pesquisadoras feministas (Lins et al., 2016).

Neste trabalho, vamos considerar que gênero é um "dispositivo cultural constituído historicamente, que classifica e posiciona o mundo a partir da relação entre o que se entende como masculino e feminino. É um operador que cria sentido para as diferenças percebidas em nossos corpos e articula pessoas, emoções, práticas e coisas dentro de uma estrutura de poder. Os arranjos de gênero colocados em prática na sociedade exercem uma força sobre toda a nossa vida cotidiana" (Lins et al., p.10).

Para compreender melhor as questões de gênero, é importante apresentar breve historicização do feminismo, movimento de luta por igualdade de direitos entre homens e mulheres. Nesse movimento são identificados três momentos conhecidos como "ondas" (Lins et al., 2016):

1. A primeira onda ocorreu entre o fim do século XIX e o início do século XX, e ficou conhecida como "sufragismo", uma vez que uma das bandeiras de luta era o direito ao voto, entre outras, como o direito à propriedade, o acesso à educação e o fim do casamento arranjado.

2. A segunda onda ocorreu entre os anos 1960 e 1970 e tinha como lema "o pessoal é político". Neste momento, as feministas abordavam questões específicas da mulher como suas 
condições de vida e de trabalho. Estavam em pauta o controle de sua sexualidade, o questionamento da sua restrição ao papel de mãe e dona de casa, as diferenças salariais entre homens e mulheres, o acesso às creches, a proibição do aborto e a violência doméstica e sexual. Neste período, manifesta-se também o feminismo negro, que apontava a necessidade de não generalização das mulheres e suas necessidades: enquanto as mulheres brancas de classe média lutavam pelo direito ao trabalho, as mulheres negras já trabalham em situações precárias desde a escravidão.

3. A terceira onda feminista se iniciou na década de 1990 e se estende até os dias de hoje e nela são reforçados os direitos de todas as mulheres, bem como da população LGBTT (Lésbicas, Gays, Bissexuais, Travestis e Transexuais). Tem como premissa considerar as diferentes mulheres e suas necessidades e aprofunda o conceito de "interseccionalidade" cunhado pelas feministas negras da segunda onda - é preciso considerar os marcadores da diferença interseccionados como gênero, raça/etnia, classe social, faixa etária entre outros, para compreender as necessidades e firmar as pautas de luta do movimento feminista.

Durante a segunda onda feminista se cunhou o termo "gênero", que foi amplamente utilizado, sofrendo algumas transformações. É importante ressaltar que o movimento feminista tem diversas correntes, cada uma apresentando diferentes explicações para a origem da subordinação das mulheres aos homens e diferentes pautas e soluções para lidar com a dominação masculina. Assim, também há maneiras diversas de se compreender o que seja "gênero" (Lins et al., 2016).

Em um artigo científico, Martins (1991) aponta que os estereótipos de gênero influenciam a maneira como a ciência investiga e nomeia os processos. A autora fez um levantamento dos verbos e adjetivos atribuídos ao óvulo e ao espermatozoide na literatura científica e didática, comprovando que o processo de fecundação é descrito como a saga de um herói - o espermatozoide, em busca de sua donzela - o óvulo. Com o tempo, foi se compreendendo que ambos gametas desempenhavam papéis ativos no processo de fecundação. Mesmo assim, a maneira de descrição continuou atribuindo ao espermatozoide ações de busca, investidas e superação, enquanto ao óvulo restava aguardar, ser penetrado e receber. Martins problematiza a questão que a naturalização desses estereótipos de gênero em nível celular pode vir a justificar ações, que implicam diretamente no âmbito social. Como, por exemplo, a proibição do aborto ente outras. 
Outra evidência de influência da ciência pelas questões de gênero, entre outros fatores que se interconectam (racismo), é a da história de desenvolvimento da ginecologia moderna. James Marion Sims, considerado o "pai da ginecologia", em meados do século XIX (1850), realizava em um galpão em seu quintal, experimentos sem a utilização de anestesias e nem procedimentos antissépticos, já existentes àquela época. Suas “cobaias" eram mulheres negras que foram escravizadas. Ele justificava o não uso de anestesia para que, essas mulheres ao sentirem dor, demonstrassem a melhor maneira de realizar os procedimentos cirúrgicos. Às custas do sofrimento destas mulheres, ele criou instrumentos como o espéculo e diversas técnicas como a da reparação de fístula vaginal, de extração de pedras na vesícula e de tratamentos de fertilidade (inseminação artificial) ${ }^{3}$.

Desde o Brasil Colonial são produzidos estereótipos femininos (e masculinos) que permeiam a formação da nossa sociedade. É importante ressaltar que no período colonial (assim como atualmente) havia diversas possibilidades de ser mulher de acordo com etnias, classes e as diferentes formas de imposição de códigos morais e padrões sociais. Às mulheres nativas foi atribuído o nome de índias, que eram consideradas selvagens sem fé e devassas por "mal cobrirem as suas vergonhas" e, assim como a terra conquistada, seu corpo era considerado passível de controle e violação pelos colonizadores. As mulheres negras escravizadas eram amaldiçoadas perante a igreja católica, sendo consideradas propriedades dos escravocratas. Assim, a sua exploração sexual era tida como natural àqueles que eram “donos" de seus corpos e suas vidas. Já às mulheres brancas, era incutido o papel de povoamento ordenado da colônia com herdeiros legítimos e com a difusão do catolicismo. Elas deveriam ser puras e submissas, representantes da "moral e bons costumes" e, independentemente de suas condições de violência doméstica e traições, deviam fidelidade e recato aos seus senhores (Lacerda ${ }^{4}, 2010$, apud Soares et al., 2015) - "belas, recatadas e do lar".

O movimento feminista no Brasil e a discussão de gênero influenciaram a produção acadêmica e o surgimento de grupos de pesquisa e disciplinas, o que culminou em propostas

3 “'Pai' da ginecologia moderna fez experiências com escravas negras. A sua estátua foi agora retirada do Central Park" [Internet] [citado 15 de mai.2018]. Disponível em: https://www.publico.pt/2018/04/20/mundo/noticia/estatua-do-pai-da-ginecologia-modernaretirada-do-central-park-1811113

4 Lacerda MB. As mulheres no Brasil Colonial. In: Colonização dos corpos: Ensaio sobre o público e o privado. Patriarcalismo, patrimonialismo, personalismo e violência contra as mulheres na formação do Brasil. [Internet] [ citado 24 de mai.2018] Rio de Janeiro, 2010. Disponível em: https://www.maxwell.vrac.puc-rio.br/acessoConteudo.php?nrseqoco=56439. 
de mudanças em políticas e serviços no âmbito da Segurança, da Justiça e da Saúde (Bandeira, 2014). Porém, há muito o que se avançar. Uma pesquisa recente da Fiocruz comprovou que as mulheres negras recebem menos anestesia na hora do parto do que as brancas, com a justificativa clínica de que seriam mais resistentes à dor.

Em “A medicalização do corpo feminino", Vieira (2002, p.19) apresenta historicamente a transformação do corpo em objeto da medicina, e afirma que "o discurso médico se apodera de certos temas e os reduz à sua condição biológica". Nestes termos, medicalizar significa, exatamente, essa objetificação da vida cotidiana, conforme as normas sociais. Como exemplo de "doentificação" tem-se o tratamento da gravidez e da menopausa como doenças, a menstruação como distúrbio crônico e o parto como evento cirúrgico (Ehrenreich; English ${ }^{5}$, 1973, apud Vieira, 2002, p.24). Assim, a autora aborda a visão médica em que a "reprodução é focalizada na mulher e na necessidade da sociedade controlar suas populações" (Vieira, p.21). Desta forma, o corpo feminino deve estar de acordo com as normas sociais vigentes, ou seja, as mulheres devem ser casadas e terem filhos, para assim atingirem uma vida saudável (Turner' ${ }^{6}$, 1987, apud Vieira, 2002, p.26).

Na segunda metade do século XIX, devido ao crescimento das cidades, houve também aumento da mortalidade. Assim, num primeiro momento, a medicina responde a esta demanda social com práticas higienistas e, juntamente com o Estado, atribuiu às mães a tarefa de zelo pelo lar e sobrevivência das crianças, reiterando a imposição do valor da mulher a partir de sua condição materna. Num segundo momento, a medicina propõe um tipo adequado de indivíduo para o aprimoramento da população e da raça/etnia, ou seja, valorizando os padrões físicos e moralmente aceitáveis de acordo com um determinado projeto social. Portanto, ou a mulher se ocupava das funções tradicionais ou era enquadrada em anomalias tidas como típicas do sexo feminino, decorrentes da negação de sua condição natural - negar o modelo ideal de mãe e esposa é estar doente. A mulher é ao mesmo tempo considerada incapaz de ser autônoma, sendo necessário ser tutelada e responsável pela transmissão da moral. A medicina e o Estado a partir das determinações biológicas - capacidade de gestar, parir, amamentar e menstruar - justificam as questões sociais como a divisão sexual do trabalho e a essencialidade da divisão de gêneros, de acordo com o sexo. É também deste pensamento que

\footnotetext{
${ }^{5}$ Ehrenreich B, English D. Complaints and Disorders: the sexual politics of sickness. Londres: Writers and Readers Publisher Cooperative; 1973. 94p.

${ }^{6}$ Turner B. Medical Power and Social Knowlegde. Londres: Sage Public; 1987. 273p.
} 
se originam diversas teorias da psiquiatria, em que se nomeia a loucura menstrual e a terapêutica da repressão da sexualidade para tratá-la (Vieira, 2002). Assim,

a relação que se estabeleceu entre a psicologia feminina e sua genitalidade especifica a construção que se fez do feminino, enquanto características de seres à beira da loucura ao menor desvio, nos quais a potencialidade da demência e da alienação possuía alicerces orgânicos incontestáveis, virtualidades da loucura. $\mathrm{O}$ gênero feminino constrói-se então, sancionado como verdade pela incontestabilidade da ciência, inexoravelmente natural, no espaço estreito de uma normalidade reprodutora. Estas ideias sobre o feminino são fundamentais para entendermos hoje como se constrói a identidade social das mulheres (Vieira, 2002, p.71).

\subsubsection{Gênero e Políticas Públicas de Saúde}

As políticas públicas são diretamente influenciadas pelo discurso médico, que por sua vez também traduz e é porta-voz da organização social e do Estado. A medicina tem sido forte aliada na reiteração dos estereótipos de gênero. Ao medicalizar a vida cotidiana, objetificando as normas sociais e reduzindo as atividades humanas à condição biológica, o discurso médico em consonância com as demandas do Estado, dita regras para a reprodução social (Vieira, 2002). Em contrapartida e como dito anteriormente, os movimentos sociais e outros tipos de discurso científico também influenciam o planejamento e a execução destas políticas.

De acordo com Barbosa (2006), a construção de políticas públicas está inserida tanto no campo conceitual quanto ético e político em que discursos e práticas de assistência à saúde estão em constante disputa. De um lado a saúde é entendida como direito de cidadania e dever do Estado, em contraposição, a saúde é vista como bem de consumo acessível a quem pode comprá-la (viés neoliberal). Estes paradigmas também orientam a construção do conhecimento em saúde. Desta forma, os textos das declarações e políticas públicas não são suficientes para fomentar mudanças substanciais nos modelos de atenção, as práticas de saúde e o próprio perfil epidemiológico da população.

A seguir, serão apresentadas duas políticas nacionais que propõem estratégias de cuidado a mulheres sob a perspectiva de gênero e outros marcadores sociais da diferença como raça/etnia e classe social, mas ainda podemos observar uma "enorme distância entre programas e a realidade sanitária e assistencial” (Barbosa, 2006, p.327) 


\subsubsection{A Política Nacional de Assistência Integral à Saúde da Mulher (PNAISM)}

Como dito anteriormente, nas décadas de 1930, 50 e 70, a saúde da mulher no Brasil era limitada às demandas da gravidez e do parto, e era organizada através do programa materno-infantil, que apresentava uma visão restrita sobre as mulheres de acordo com sua especificidade biológica e o papel social, que lhes era (é) atribuído/imposto, papel de mãe e doméstica, cuidadora do lar e da família. Este processo de construção da assistência à saúde das mulheres foi inicialmente mais restrito ao papel materno incutido à população feminina, focando em ações de saúde reprodutiva. Por esse motivo sofreu diversas críticas do movimento feminista (Brasil, 2014).

Portanto, a partir da influência das pesquisas e da luta social, em 1984, foi criado o Programa de Assistência Integral à Saúde da Mulher (PAISM), a primeira estratégia de saúde pública exclusiva para mulheres, que aborda de maneira ampliada as necessidades das mulheres. Porém, ressaltamos que apenas as ações de ginecologia e obstetrícia foram implementadas, denotando a influência do conservadorismo e dos estereótipos de gênero na proposição de políticas públicas e na produção científica (Bandeira, 2014). Mesmo com a incorporação do objetivo da atenção integral à saúde da mulher, a delimitação das ações básicas mínimas como prioridades dificultou a atuação sobre outras necessidades de saúde das mulheres (Brasil, 2004). Ficaram evidentes diversas lacunas, entre elas a saúde mental e a inclusão da perspectiva de gênero e raça/etnia nos cuidados em saúde (Brasil, 2014, p.18).

Compreendendo então a maneira restritiva com que ainda é abordada a "Saúde da Mulher" em todos os níveis de atenção à saúde, em 2003 é criada a Política Nacional de Assistência Integral à Saúde da Mulher (PNAISM).

O documento "PNAISM - Princípios e Diretrizes" de 2004, trata-se de proposta de incorporação da perspectiva de gênero para análise do perfil epidemiológico da população brasileira e para oferta das ações, visando a melhoria das condições de vida e igualdade de direitos de cidadania da mulher. O referido documento afirma que "mulheres e homens, em função da organização social das relações de gênero, também estão expostos a padrões distintos de sofrimento, adoecimento e morte" (Brasil, 2014, p.13). Também afirma que gênero é um "conjunto de relações, atributos, papéis, crenças e atitudes, que definem o que significa ser homem ou ser mulher" (Brasil, 2014, p.12). De modo que os consequentes 
desequilíbrios entre os gêneros refletem-se nas leis, políticas e práticas sociais, identidades, atitudes e comportamentos das pessoas.

\subsubsection{O Núcleo de Apoio à Saúde da Família (NASF)}

A ESF é a vertente brasileira da Atenção Primária à Saúde e é elencada pelo MS como modelo de Atenção Básica a ser assumido gradualmente por todos os municípios.

Seu principal propósito é "reorganizar a prática da atenção à saúde em novas bases e substituir o modelo tradicional, levando a saúde para mais perto das famílias e, com isso, melhorar a qualidade de vida da população". Assim, a ESF é "o primeiro contato na rede assistencial [...] caracterizando-se, principalmente, pela continuidade e integralidade da atenção, além da coordenação da assistência dentro do próprio sistema, da atenção centrada na família, da orientação e participação comunitária e da competência cultural dos profissionais" (Brasil, 2009, p.9).

Os NASF são propostos pela Portaria $n^{\circ} 154$ do MS, em janeiro de 2008. Trata-se de constituir equipes interdisciplinares mediante prioridades, necessidades locais e disponibilidade das categorias. Estas equipes devem atuar em conjunto com as equipes da ESF, compartilhando e apoiando as práticas de saúde, mas não se constituindo como porta de entrada do sistema (Brasil, 2009, p.7).

A composição das equipes NASF foi modificada pela Portaria $n^{0} 3124$ de 2012, do MS, que indicou três tipos de NASF: o NASF 1 deve ofertar no mínimo 200 horas semanais (soma da carga horária de trabalho de todos as profissionais) e apoiar de cinco a nove equipes de SF; o NASF 2 deve ofertar no mínimo 120 horas semanais e apoiar de três a quatro equipes de SF; e o NASF 3 deve ofertar no mínimo 80 horas semanais e apoiar de uma a duas equipes de SF.

Poderão compor o NASF as seguintes categorias: médico acupunturista; assistente social; profissional/professor de educação física; farmacêutico; fisioterapeuta; fonoaudiólogo; médico ginecologista/obstetra; médico homeopata; nutricionista; médico pediatra; psicólogo; médico psiquiatra; terapeuta ocupacional; médico geriatra; médico internista (clínica médica); médico do trabalho; médico veterinário; profisssional com formação em arte e educação (arte educador); profissional de saúde coletiva/sanitarista, ou seja, profissional graduado na área de 
saúde com pós-graduação em saúde pública ou coletiva ou graduado diretamente em uma dessas áreas (Brasil, 2012).

Recomenda-se, no Artigo $4^{\circ}$ da Portaria $n^{\circ} 154 / \mathrm{MS}$ de 2008 no $2^{\circ}$ Parágrafo, que devido à magnitude epidemiológica dos transtornos mentais, cada NASF conte com pelo menos 1 profissional da área de saúde mental, a saber: psicólogo, psiquiatra ou terapeuta ocupacional (Brasil, 2008).

Para apresentar a caracterização inicial do trabalho, a composição das equipes e as ferramentas a serem utilizadas, em 2009, o MS lança o "Caderno de Atenção Básica n²7 Diretrizes do NASF" (Caderno AB 27). As atividades das profissionais do NASF podem ser diversas, desde que contemplem as nove áreas estratégicas de sua atuação, a saber: saúde da mulher; saúde mental; reabilitação/saúde integral da pessoa idosa; saúde da criança/do adolescente e do jovem; alimentação e nutrição; serviço social; assistência farmacêutica; atividade física/práticas corporais; práticas integrativas e complementares. Além disso, a organização do trabalho depende de ferramentas complexas e pouco difundidas nas formações profissionais: o Apoio Matricial, a Clínica Ampliada, o Projeto Terapêutico Singular (PTS), o Projeto de Saúde do Território (PST) e a Pactuação do Apoio. Em tais ferramentas "a constituição de uma rede de cuidados é uma das estratégias essenciais dentro da lógica de trabalho de um NASF [...] de forma corresponsabilizada com a ESF” (Brasil, 2009, p.8).

A saúde da mulher é uma das áreas estratégicas de atuação do NASF - "Atenção Integral à Saúde da Mulher no NASF”, em que

a abordagem de gênero representa um referencial importante para melhor compreensão dos agravos à saúde da mulher e a construção de ações de prevenção de agravos e promoção de saúde efetivas, além de propiciar o empoderamento da comunidade e das mulheres em particular, especialmente nos campos da violência doméstica, do planejamento familiar e da saúde mental. E, em relação ao planejamento familiar, a abordagem da sexualidade nos seus significados culturais e de gênero, bem como o entendimento do aspecto sociocultural da família, possibilita a ampliação da ação das equipes da SF para além da distribuição de anticoncepcionais [...] que contemplem os vários objetivos do Plano Nacional de Atenção à Saúde da Mulher (Brasil, 2009, p.123).

O Caderno AB 27 destaca "A saúde mental da população feminina" e "Violência contra a mulher e violência intrafamiliar". Nesses tópicos é problematizada a grande incidência de transtornos mentais comuns nas mulheres e a assistência prestada, restrita à prescrição excessiva de psicofármacos, especialmente benzodiazepínicos, ou apenas à renovação destas receitas iniciadas em outros serviços. Mais uma vez, aponta-se a 
importância da ampliação do olhar e do cuidado em saúde prestado às mulheres, com proposição de ofertas para além das de saúde reprodutiva. Outro documento sobre o trabalho do NASF aponta o "Papel dos grupos" no manejo compartilhado destas situações de sofrimento vividas pelas mulheres (Brasil, 2009, p.8).

A seção do Caderno AB 27, "Saúde Mental no NASF", salienta um estudo realizado sobre a demanda de equipes de ESF da periferia de São Paulo, em que há prevalência de 24,58\% de transtornos mentais comuns (como depressão e transtornos de ansiedade), sendo que os grupos mais vulneráveis são mulheres, idosos, pessoas com baixa escolaridade e menor renda per capita (Brasil, 2009, p.38).

Pode-se notar que há aspectos da concepção do NASF que contemplam diversos apontamentos da PNAISM sobre a ampliação do cuidado em saúde às mulheres. Na prática, porém, discute-se muito pouco a atuação interdisciplinar e em grupos. Assim, a ampliação do olhar para as necessidades de saúde da população é restrita e até mesmo incipiente. Como o próprio SUS, o NASF é recente e está em processo de implementação. Sendo assim, entendese que haverá muitas diferenças na constituição das equipes de NASF e nas estratégias de cuidado que ofertam. Bem como nas parcerias que estabelecem com as equipes da ESF e os outros serviços da rede. Enfim, diversas formatações são esperadas devido também ao perfil epidemiológico do território em que se inserem e as políticas de Estado relacionadas à situação.

Os NASF foram implantados na cidade de São Paulo em 2009 e "todo o processo de implantação do NASF foi pautado no entendimento que a contratação dessas profissionais não consistia na inserção de uma rede nova de serviços, mas sim uma estratégia de ampliar e qualificar a assistência, fortalecendo a rede de cuidados existente" (São Paulo, 2009, p.3, grifos do autor). Desta forma, os NASF são uma oportunidade de inserção de diversas categorias profisssionais na Atenção Básica, antes esperadas apenas nos serviços de atenção especializada.

De acordo com o documento "Diretrizes e Parâmetros norteadores das ações dos NASF", da Secretaria Municipal de Saúde de São Paulo (SMS/SP), deve haver "a priorização de profissionais das áreas de saúde mental, reabilitação, pediatria e ginecologia" (São Paulo, 2009, p.2).

Porém, apesar dos documentos sobre a implementação do NASF no município estarem de acordo com as propostas do MS, estas equipes têm sofrido as consequências das 
mudanças de governo municipal e de seus respectivos projetos político-sociais com repercussões diretas na assistência prestada à população.

Assim, tem se observado cortes de profissionais, redução das horas de trabalho à carga mínima de 200 horas e o número insuficiente e composição de equipes de NASF, que não tendem às orientações da portaria ministerial de 2012. Este assunto será aprofundado no capítulo de apresentação do campo de pesquisa (3.2.5 As equipes de NASF do território).

\subsubsection{Gênero, Saúde e Terapia Ocupacional}

Na literatura científica, a discussão sobre gênero e saúde aparece tardiamente. Somente na década de 1980 que "violência de gênero" virou categoria sociológica e de pesquisa, sendo esta uma reivindicação feminista desde os anos de 1970. O movimento feminista brasileiro primeiramente deu visibilidade à questão da violência contra a mulher. Posteriormente, tornou pública esta discussão que trata de um problema político e de saúde pública e não apenas de um problema da esfera da vida familiar e privada. A partir de então, muitos grupos de pesquisa e disciplinas nesta área surgiram, o que promoveu mudanças no cenário político e implementação de diversos serviços nas áreas de Segurança, Justiça e Saúde (Bandeira, 2014).

Ainda de acordo com Bandeira (2014), o Programa de Assistência Integral à Saúde da Mulher (PAISM) de 1984, foi a primeira ação de saúde pública exclusiva para mulheres. Como já afirmado anteriormente, apenas as especialidades de ginecologia e obstetrícia foram amplamente implementadas nos serviços de saúde. Esta observação denota o conservadorismo para tratar da saúde da mulher, o que se percebe nas representações sociais patriarcais ainda hoje.

Aquino (2006), realizou uma pesquisa bibliográfica da produção científica brasileira sobre o tema, em que utilizou em sua busca os termos "saúde da mulher", "gênero e saúde" e "sexualidade". A partir de sua busca, identificou a primeira tese de doutorado em que o termo "gênero" é utilizado em 1992 - "Mulher e saúde mental: da importância do conceito de gênero 
na abordagem da loucura", título obtido na Universidade de São Paulo (Villela ${ }^{7}, 1992$, apud Aquino, 2006).

A autora da revisão bibliográfica aponta que a saúde mental e suas relações com as questões de gênero é um tema ainda pouco abordado, restando dúvidas sobre como a relação de gênero afeta a saúde e suas repercussões na produção científica. Além disso, os estudos se concentram na área de Ciências Sociais em Saúde e tratam em sua maioria de temas como planejamento de políticas, modelos de atenção, controle social e movimentos sociais.

Para o desenvolvimento desta dissertação também foi realizada pesquisa bibliográfica em busca de literatura cinzenta no Brasil utilizando os filtros: "terapia de grupo" AND mulher*, nenhuma ocorrência pertinente ao tema pesquisado foi encontrada.

Já, na Biblioteca Digital Brasileira de Teses e Dissertações (BDTD/IBICT), com os filtros "grupo terapêutico" AND mulher* foi encontrada uma dissertação pertinente que trata sobre grupos terapêuticos realizados por médicos e enfermeiros com apoio da equipe de saúde mental na Atenção Básica: "Cuidado em saúde mental pelo programa de saúde da família”, de autoria de Quintanilha (2013), para obtenção do título de mestre na Faculdade de Ciências Médicas do Rio de Janeiro.

Foi feita também uma prospecção com estes filtros na Biblioteca Virtual da Saúde (BVS). Com o primeiro filtro foram encontradas 23 ocorrências (11 artigos completos disponíveis, sendo três repetidos) e com o segundo, 45 ocorrências (19 artigos completos disponíveis, sendo três repetidos e um coincidente com o outro filtro). A partir desta busca, foram selecionados três artigos da primeira busca e nove artigos da segunda busca. A triagem dos artigos ocorreu por: títulos que contemplassem os temas de pesquisa, presença de resumos e possibilidade de acesso aos textos completos.

Além disso, realizou-se busca com diversos filtros na Scientific Eletronic Library Online (Scielo), porém se tratou de etapa preliminar de pesquisa bibliográfica, uma vez que em segunda tentativa não foi possível reproduzir os mesmos resultados da busca. Naquele momento de aproximação com o tema deste estudo e seu campo científico, foram selecionados diversos artigos com temas relacionados aos seguintes campos: feminismo; gênero e saúde; violência contra a mulher e violência de gênero; direitos das mulheres; sexualidade; grupos terapêuticos.

7 Villela WV. Mulher e saúde mental: da importância do conceito de gênero na abordagem da loucura feminina [tese de Doutorado]. São Paulo: Universidade de São Paulo; 1992. 187 p. 
Outra busca ocorreu nos dois periódicos brasileiros indexados do campo da Terapia Ocupacional: Revista de Terapia Ocupacional da Universidade de São Paulo e Cadernos Brasileiros de Terapia Ocupacional editado pela Universidade Federal de São Carlos, utilizando-se os mesmos filtros citados anteriormente. Dos artigos pertinentes, destaca-se um que foi publicado nos Cadernos Brasileiros de Terapia Ocupacional da UFSCar:: "A intervenção grupal como recurso da Terapia Ocupacional: uma experiência com mulheres climatéricas" de Rosa e Brançam (2013).

Os artigos e trabalhos selecionados, abordavam estratégias grupais para o cuidado de mulheres: climatéricas; mastectomizadas; com câncer de mama; puérperas; gestantes; usuárias de substâncias psicoativas. E outros trabalhos selecionados, associados ou não a teorias de gênero, feminismo e sua interface com as políticas públicas e de saúde, apresentavam intervenções com: travestis e transexuais. Ou seja, pode-se inferir que é escassa a produção científica sobre o tema. Além disso, os trabalhos encontrados que tratam de abordagens grupais para mulheres utilizam-se de recortes biomédicos e com enfoque nas questões reprodutivas.

Apenas os trabalhos sobre travestilidades é que trazem a perspectiva de gênero para a discussão. Os trabalhos encontrados abordavam experiências de determinadas categorias profissionais a partir de relatos de experiência dos núcleos específicos.

Recentemente, Maximino e Liberman (2015) organizaram um livro intitulado "Grupos e Terapia Ocupacional: Formação, pesquisa e ações", do qual destacamos o capítulo 5 "Cartografias femininas: Grupo de Mulheres pelo olhar das estudantes", que apresenta uma experiência de estágio interdisciplinar, entre os cursos, o de graduação em terapia ocupacional da Universidade Federal de São Paulo (UNIFESP) em Santos. Os estudantes dos diversos cursos da área da saúde acompanharam um Grupo de Mulheres que aconteceu em uma UBS. No referido texto, há conexões com a discussão de gênero e a importância dos grupos como estratégias de resistência das mulheres.

Desta forma, justifica-se a pertinência deste estudo de mestrado. Esta pesquisa pretende documentar, compreender e divulgar uma estratégia de cuidado destinada a esta população na perspectiva de ampliação dos cuidados dirigidos às mulheres em serviços de Atenção Básica - o Grupo de Mulheres. 


\subsection{GRUPOS}

No "Caderno de Atenção Básica n³9, vol.1 - NASF: Ferramentas para a Gestão e o Trabalho Cotidiano", de 2014 (Caderno AB 39) os grupos são apontados como potentes dispositivos de cuidado na Atenção Básica com destaque para os grupos com mulheres.

Os grupos com mulheres têm sido realizados em unidades de Atenção Básica no País há muitos anos, porém com poucos relatos publicados ou estudos de acompanhamento realizados. De maneira geral, estruturam-se como grupos de apoio e suporte, possibilitando espaços de acolhida e escuta, promovendo reflexão e reforço da autoestima e fortalecendo o vínculo com a equipe. Contribuem para a redução da busca espontânea da unidade por pacientes com queixas físicas sem explicação médica. Costumam ser grupos abertos, sem temas definidos, onde normalmente os problemas, tensões e dificuldades do dia a dia são discutidos. Neles, podem se aprimorar e trocar estratégias para lidar em melhores condições com as discriminações de gênero, a problemática da violência doméstica e as ansiedades oriundas das mudanças de ciclo vital (menopausa, crescimento dos filhos, aposentadoria etc.) (Brasil, 2014, p.69).

Ainda de acordo com o referido documento, há uma "degradação dos grupos” (Brasil, 2014, p.69), pois são organizados à maneira de consulta coletiva ou sessões informativas. Isso se deve à formação das trabalhadoras de saúde, focalizada no modelo biomédico em que é reproduzida a ideia de uma postura passiva dos usuários e onde as profissionais são detentoras do conhecimento. Desta forma, é preciso mudar a prática para que se criem os grupos, ou seja, é preciso uma abordagem de acolhimento, escuta, empoderamento e, principalmente, usuário centrada (Brasil, 2014, 2014).

Sobre este assunto, destacamos também o conteúdo do "Caderno de Atenção Básica n.34 - Saúde Mental” (Caderno AB 34) (Brasil, 2013) e sua problematização sobre grupos, ou melhor, "agrupamento[s] [...] sem nenhum sentimento verdadeiro de valor e pertencimento grupal.” (Brasil, 2013, p.123) que são tradicionalmente realizados na AB que

costumam ser orientados pelas ações programáticas, modelo hegemônico de organização da ESF, centrado nos grupos prioritários de doenças/ agravos: grupo para pessoas com diabetes, hipertensão; atividade física; planejamento familiar; grupos de adesão medicamentosa, entre outros. Os objetivos são de gerar impactos nos indicadores na perspectiva da educação em saúde, comumente baseada num paradigma de transmissão do saber-fazer profissional. Se, por um lado, as propostas desses grupos organizam um modelo amplamente difundido, por outro, esgota-se a possibilidade de diálogo devido à manutenção da repetição do discurso, centrado no saber profissional (Brasil, 2013, p.121, grifo do autor). 
Mesmo sendo uma estratégia amplamente utilizada pelos NASF, há poucos relatos sobre as práticas dos Grupos de Mulheres. Isto pode vir a fortalecer as constantes ameaças de desmonte deste programa por falta de "resultados expressivos", além de dar a impressão de que não haja nenhum tipo de alinhamento entre as propostas de trabalho do NASF (o que o Caderno AB 39 aponta ser exatamente o contrário). Porém, é importante ressaltar que as políticas públicas não são aplicadas integralmente conforme foram planejadas, da mesma forma, os NASF estão suscetíveis a leituras reducionistas de sua proposta e a práticas medicalizantes.

No município de São Paulo, por exemplo, há equipes de NASF que são reguladas por metas de produção mínima e as agendas do NASF, que já estão digitalizadas, possibilitam agendamentos de perfil "ambulatorial" a situações que não foram cuidadas na lógica da equipe de SF e do apoio matricial.

Essa pesquisa se baseia nesta provocação sobre a necessidade de "estudos de acompanhamento" sobre os Grupos de Mulheres. As reflexões aqui realizadas foram produzidas considerando que

a observação e análise dos grupos nos quais trabalhamos e a descrição detalhada que busca estabelecer sentido e inteligibilidade do que fazemos e propomos parecem ser bons caminhos para a produção de conhecimento. Trilhar o raciocínio de terapeutas ocupacionais em seu próprio fazer (Maximino; Liberman, 2015, p.18).

No campo da Terapia Ocupacional, "grande parte da nossa formação assenta-se sobre a possibilidade de narrar e compartilhar as diversas trajetórias profissionais" (Maximino; Liberman, 2015, p.23), em que

\begin{abstract}
partimos da concepção da potência do recurso grupal na intervenção da Terapia Ocupacional, bem como o planejamento e a execução de atividades no contexto do atendimento, pois favorecem entrecruzamentos e conexões entre universos subjetivos diversos e singulares. $\mathrm{O}$ que é manifesto vem carregado de significações que, no contato com o outro, podem adquirir ainda novos significados, explicitando diferenças e semelhanças, traços culturais distintos, marcas das histórias e desejos (Samea ${ }^{8}$, 2008, apud Rosa; Brançam, 2013, p.425).
\end{abstract}

Todas estas considerações ancoram um importante objetivo desta pesquisa: investigar a prática do Grupo de Mulheres e como este trabalho tem respondido às necessidades de saúde das mulheres. Um questionamento colocado é: “o desenvolvimento do Grupo de

8 Samea M. O dispositivo grupal como intervenção em reabilitação: reflexões a partir da prática em terapia ocupacional. Rev Terapia Ocupacional Univ São Paulo; 2008. 19(2): 85-90. 
Mulheres tem incluído as questões de gênero ou o funcionamento do Grupo apenas responde ao modelo hegemônico na $\mathrm{AB}$ de 'queixa-conduta"'?

Mesmo com estas indagações, é possível afirmar que o Grupo de Mulheres tem sido conduzido no sentido de cuidar das necessidades ampliadas de saúde das mulheres deste território.

\subsection{NECESSIDADES DE SAÚDE}

De acordo com Campos e Bataiero (2007) necessidades de saúde são necessidades de reprodução social, sendo assim, dependem da presença do Estado, das condições da reprodução social e da participação política dos sujeitos.

Os autores utilizam o conceito de necessidade cunhado por Marx e Engels (1993), em que a necessidade é algo que precisa ser satisfeito para que a vida continue. A satisfação de determinada necessidade se dá através de um produto, fruto de um processo de trabalho humano. Ou seja, a necessidade gera trabalho e este, por sua vez, gera o produto para responder a esta necessidade que, quando satisfeita, impulsiona o surgimento de outra necessidade. Desta forma, o trabalho aprimora as necessidades humanas que, se respondidas, têm a potência de aperfeiçoar a essência humana (Campos e Bataiero, 2007).

Com o advento do capitalismo, o trabalho passa a ser realizado não mais para satisfazer as necessidades, mas para produzir excedentes e as necessidades dos sujeitos vão sendo convertidas em necessidades por produtos. E da mesma forma, as necessidades de saúde também são moduladas pelo capitalismo e suas instituições (Campos e Bataiero, 2007):

as necessidades humanas foram se tornando indiferenciadas e se tornando em necessidades de ter, o que diferencia as respostas a elas é o acesso aos produtos que as aplaca, acesso esse distinto nas diferentes classes/grupos sociais (Campos, 2009, p.147, grifo do autor).

Os produtos ofertados para responder às necessidades de saúde são procedimentos, em sua maioria, consultas e artigos da área hospitalar. Tem ficado evidente que somente as necessidades de saúde reconhecidas, por exemplo pelo Banco Mundial, são respondidas pelos serviços. $\mathrm{O}$ que reitera aos sujeitos que a única possibilidade de respostas às suas necessidades de saúde são consultas médicas, exames e medicamentos, retroalimentando as suas 
necessidades - os sujeitos passam a necessitar somente daquilo que lhes é ofertado (Campos e Bataiero, 2007).

Assim, a saúde é exercida não como direito social, mas como escolha individual, que depende do acesso às possibilidades de bens de troca, de comportamentos e de estilos de vida, aumentando a responsabilização individual e diminuindo a pressão social sobre o sistema público (Campos e Bataiero, 2007).

As práticas de saúde têm como finalidade atender necessidades de saúde [...] as necessidades colocadas em primeiro plano podem não ser as da população, mas sim a dos gestores, a dos programas, ou seja, os interesses de diferentes setores da sociedade civil podem concorrer com as necessidades [...] [têm] prioridade os interesses dos grupos que têm mais poder [...] as necessidades não são naturais - não nascem com as pessoas, nem são homogêneas - são constituídas historicamente e dependem da inserção social dos indivíduos [...] Da mesma forma que as necessidades são historicamente constituídas, também o são as respostas a elas (Campos, 2009, p.142-4).

Para a autora, de acordo com o Banco Mundial, as necessidades de saúde das mulheres devem se resumir à reprodução - pré-natal e puerpério (Campos e Bataiero, 2007) e a resposta a tais necessidades é circunscrita a consultas, exames e procedimentos, exatamente o que encontramos majoritariamente nas práticas da $\mathrm{AB}$.

Em contraposição ao preconizado pelas políticas, a principal necessidade de saúde das mulheres da UBS A" tem sido as suas situações de sofrimento, e o Grupo de Mulheres tem sido uma importante ferramenta de cuidado destas situações.

\subsection{SOFRIMENTO}

De acordo com o Caderno AB 34, consideramos o sofrimento como uma "vivência da ameaça de ruptura da unidade/identidade da pessoa [...] torna-se fundamental para o profissional da $\mathrm{AB}$ manter-se atento às diversas dimensões do sujeito que se apresenta a sua frente" (Brasil, 2013, p. 32).

Um sofrimento pode se manifestar se uma pessoa é privada de qualquer uma ou várias das dimensões do sujeito (Brasil, 2013, p.29-31). Quanto às dimensões do sujeito, toda pessoa tem (Brasil, 2013, p.29-30):

- passado, memórias e visão de mundo; 
- futuro, desejos e sonhos;

- autoimagem

- é um ser político com direitos e obrigações;

- faz coisas, tem hábitos;

- mundo inconsciente;

- (pode ter) visão transcendente, como sendo parte de algo atemporal e ilimitado;

- vida e história familiar, papéis e pertencimento;

- vida de trabalho;

- mundo cultural;

- corpo anatômico e corpo vivido com relações e emoções.

Além destas situações relacionadas às dimensões do sujeito, um sofrimento também pode ocorrer se a pessoa apresenta fatores de vulnerabilidade (discriminação por gênero, pobreza, cor da pele, etc.), se está em um momento de desestabilização (eventos de vida e seus significados), e da sua resiliência (temperamento e apoio social) (Brasil, 2013, p.92-3). Tudo isto deve ser considerado pela profissional de saúde no momento de sua avaliação e na proposição dos cuidados.

De acordo com o referido documento:

à medida que as pessoas interagem com os ambientes em que vivem, essas esferas, que compõem as pessoas, vão se constituindo e formando sua própria história, cada uma seguindo uma dinâmica própria com regras e parâmetros para um modo de viver específico. Paralelamente, as esferas influenciam umas às outras [...] são interdependentes (Brasil, 2013, p.31).

Estar no mundo produz todo tipo de relações e emoções. Tristeza, desânimo, perda do prazer de viver, irritabilidade, dificuldade de concentração, ansiedade e medo (às vezes na forma de crises) são queixas comuns dos usuários na $\mathrm{AB}$, que costumam estar associadas entre si. Outras queixas também são recorrentes: mudança no sono e apetite, dores, cansaço, palpitações, tontura ou mesmo alterações gástricas e intestinais (Goldberg; Huxley ${ }^{9}$, 1992, apud Brasil, 2013, p. 90-91).

São queixas denominadas como sofrimentos comuns e reconhecidas como sintomas depressivos (tristeza/desânimo), ansiosos e de somatização (sintomas físicos sem explicação médica) (Brasil, 2013, p. 90-1). Há também outras situações de sofrimento que implicam

9 Goldberg DP, Huxley P. Common mental disorders - A biosocial model. London: Routledge; 1992. $224 \mathrm{p}$. 
usuários de álcool e outras drogas e ainda, pessoas com sofrimentos graves e persistentes, como as psicoses. Porém, todas estas pessoas apresentam situações de sofrimento que impactam diretamente em sua produção de vida, assim, independente do diagnóstico, devem receber escuta e cuidados.

Portanto, há razões suficientes para defender que as manifestações mais comuns do sofrimento mental na $\mathrm{AB}$ fazem parte de uma única síndrome clínica com três grupos ou dimensões de sintomas que se combinam: tristeza/desânimo, ansiedade e sintomas físicos (somatização) (Brasil, 2013, p.91).

Estas situações de sofrimentos comuns são as principais queixas apresentadas pelas mulheres na $\mathrm{AB}$, e mesmo com sintomas parecidos, as histórias de vida e rupturas são muito distintas, porém com uma grande questão em comum: gênero.

Porém, lidar com o sofrimento das mulheres da UBS A" é uma das principais dificuldades apontadas pelas trabalhadoras, que compreendem não terem formação para tal. $\mathrm{O}$ trabalho em equipe interprofissional é um arranjo que teoricamente facilitaria que tais dificuldades fossem gradativamente superadas, mas, o que vemos é a implantação parcial desta proposta na UBS A", em que coexistem dois modelos de AB. Portanto, para além das dificuldades da formação das trabalhadoras, reconhecidamente focada no modelo biomédico, a organização do serviço não viabiliza a clínica ampliada para o cuidado das situações de sofrimento.

\subsection{TRABALHO INTERPROFISSIONAL}

A formação profissional em saúde baseia-se em diversas influências. A primeira tentativa de organização do ensino em saúde ocorreu em 1910 nos EUA, através do Relatório Flexner em que houve segmentação do ensino entre ciclos básico e profissional. A disposição das disciplinas estava de acordo com as especialidades e práticas ambientadas no hospital, denotando a influência do paradigma da medicina científica neste processo (Santana et. al, 1999).

Concomitantemente, na Inglaterra no Pós-guerra, ocorreu a estruturação do Serviço Nacional de Saúde, e mesmo nos EUA, em 1940, desenvolveu-se a Medicina Comunitária. 
Nesta época, temos também os primeiros departamentos de medicina preventiva no Chile (Santana et. al, 1999). Surge, portanto, um movimento de superação do modelo flexneriano de ensino e práticas em saúde, o que culminou nas propostas de integração docente-assistencial, que abordam a necessidade de exposição precoce dos estudantes às realidades sanitárias para além dos hospitais (Santana et. al, 1999).

É importante considerar que no Brasil, na década de 1970, houve um aumento importante das ofertas e da procura pelos cursos de saúde, sendo assim, toda essa mão de obra do setor saúde não seria absorvida nos hospitais (Santana et. al, 1999).

Porém, em 1978, a Declaração de Alma Ata, através da máxima "saúde para todos", preconiza a importância da Atenção Primária. Com a implementação da AB no Brasil, houve aumento das vagas e absorção dos profissionais (Santana et. al, 1999).

Mesmo com estas tentativas de superação do modelo biomédico, ainda persiste a fragmentação do cuidado em departamentos de acordo com as especialidades e consequente diluição da responsabilidade sanitária. Isto fragmenta também o processo de trabalho e a unidade de gestão, criando dificuldades para a integração de diagnósticos e terapêuticas. Assim, é possível afirmar que tal fragmentação se configura como obstáculo estrutural para a prática da clínica ampliada e o trabalho interdisciplinar (Campos, e Domitti, 2007).

Ainda de acordo com Campos e Domitti (2007), o trabalho interdisciplinar depende de uma predisposição subjetiva das trabalhadoras para lidar com a incerteza, receber e fazer críticas e discussões compartilhadas. Essa predisposição não é o padrão das subjetividades nas instituições contemporâneas, pois com o aumento da concorrência, aumenta a paranoia e o apego ao núcleo profissional.

Considerando a importância do trabalho interdisciplinar para o cuidado em saúde, o Ministério da Saúde lançou em 1998 a Resolução n²87, que dispõe sobre as 14 categorias profissionais de saúde e a importância da ação interdisciplinar.

Reitera-se, a partir da discussão da literatura científica, a importância dos temas "gênero", "abordagens grupais" e "trabalho interprofissional" para a formação do trabalhador em saúde. É mundialmente reconhecido que a Prática Interprofissional (PIP) aumenta a resolubilidade e a qualidade da atenção à saúde, uma vez que

permite otimizar os recursos e a atenção às necessidades de saúde próprias de usuários e população de cada território e serviço, visto que as necessidades são heterogêneas e complexas e requerem ser apreendidas de 
forma integral (Organização Mundial da Saúde, ${ }^{10} 2010$, apud Peduzzi et al., 2013, p.977).

Barbosa (2006) afirma que "a interdisciplinaridade no campo da assistência à saúde é uma necessidade inadiável e está intimamente conectada às demandas pela integralidade e humanização" (p.324) considerando que

o processo saúde e doença remete a dimensões fundamentais da vida humana, colocando em xeque desde as desiguais e injustas relações sociais, incluindo-se as de gênero e raciais/étnicas, que solapam o direito à saúde da maioria das populações do planeta, até o complexo entrelaçamento entre história, cultura e subjetividade que se materializa nas formas como os diferentes grupos sociais lidam como o corpo, a saúde e a doença (Minayo ${ }^{11}$, 1992, apud Barbosa, 2006, p.324).

Uma das características da formação para a PIP é o foco nas necessidades de saúde das populações. Desta forma, ao se considerar a complexidade das necessidades de saúde, tornase imprescindível abordar as questões de gênero no cuidado em saúde. As abordagens grupais são importantes ferramentas para exercitar estes cuidados no sentido da otimização dos recursos e da compreensão da determinação social dos sofrimentos deste grupo populacional.

Diante deste cenário de medicalização do sofrimento, da não neutralidade das profissões de saúde e da influência das questões de gênero em nossas práticas é importante questionar "¿cúanto de ello [cuéstion de género] incluimos los terapistas ocupacionales en el análisis de las ocupaciones y/o actividades a la hora de instrumentar dispositivos y decidir estrategias terapéuticas?” (Testa; Spampinato, 2010, p.179). Quanto das questões de gênero incluímos - profissionais de saúde, no momento de fazer a leitura das necessidades de saúde e ofertar cuidado às mulheres que assistimos?

10 World Health Organization. Framework for action on interprofessional education \& collaborative practice. Geneva: WHO; 2010. 64 p.

11 Minayo MCS. O desafio do conhecimento: pesquisa qualitativa em saúde. São Paulo, Rio de Janeiro: Hucitec, Abrasco; 1992. 269 p. 


\section{A PESQUISA}

\subsection{PRINCIPAIS ASPECTOS METODOLÓGICOS}

Esta é uma pesquisa de caráter qualitativo, descritivo e exploratório (Silveira e Córdova, 2009), que tem como objetivo descrever e problematizar uma experiência de cuidado a mulheres numa UBS, no âmbito da ESF em parceria com o NASF, considerando a integralidade, as questões de gênero e a ampliação do cuidado.

Enquanto método para abordar o objeto acima exposto, optou-se pela pesquisa qualitativa organizada sob forma de um estudo de caso. Segundo Creswell (2014, p.87, grifo do autor), "a pesquisa de estudo de caso é uma abordagem qualitativa na qual o investigador explora um sistema delimitado contemporâneo da vida real (um caso) ao longo do tempo, por meio da coleta de dados detalhada em profundidade envolvendo múltiplas fontes de informação [...] e relata uma descrição do caso e temas do caso".

Ainda de acordo com Creswell (2014), um estudo de caso deve abordar uma situação única - a experiência de cuidado e o Grupo de Mulheres realizados na UBS A

Desta forma, a partir do questionamento "Quais os indivíduos sociais têm vinculação mais significativa para o problema a ser estudado?” (Minayo, 2006, apud Deslandes, 2009, p.48 $)^{12}$, quatro usuárias, participantes do Grupo de Mulheres, foram convidadas a participar deste estudo.

Os casos foram selecionados intencionalmente por serem considerados itinerários terapêuticos complexos e que a fundo, são também inspiradores para os questionamentos propostos nesta pesquisa. Estas usuárias foram convidadas a participar do referido Grupo de Mulheres pela pesquisadora no momento de proposição de cuidados e o vínculo com estas mulheres facilitou a manutenção do contato e que também fossem acionadas para a realização da pesquisa. Além disso, a experiência de cuidado e a relação terapeuta-paciente estabelecida com estas mulheres propiciou uma maior relação com suas histórias de vida e uma reflexão mais aprofundada sobre seus itinerários terapêuticos e respectiva influência na formação profissional da pesquisadora. Como relatado no projeto de pesquisa, não sendo possível

12 Minayo MCS. O desafio do conhecimento: pesquisa qualitativa em saúde. São Paulo, Rio de Janeiro: Hucitec, Abrasco; 1992. 269 p. 
realizar as entrevistas com estas mulheres, outras participantes do grupo seriam acionadas, porém, as quatro mulheres inicialmente acionadas, aceitaram participar, não havendo necessidade de novos contatos com outras usuárias do Grupo.

Da mesma forma, as profissionais colaboradoras da pesquisa foram escolhidas intencionalmente, no sentido do tempo de experiência no serviço de saúde pesquisado. No momento da coleta de dados, diversas profissionais da categoria médica, filiadas ao programa "Mais Médicos", encontravam-se em fim de contrato, assim, foi possível garantir a entrevista com apenas uma destas profissionais. Portanto, optamos por entrevistar todas as seis enfermeiras de ESF, e não as referências dos casos como proposto no projeto de pesquisa, a fim de um cenário mais amplo das práticas de cuidado a mulheres e uma avaliação mais apropriada do Grupo de Mulheres. Também foi realizada entrevista com uma Agente Comunitária de Saúde (ACS), no sentido de garantir o acesso ao discurso desta importante categoria profissional durante a pesquisa. A referida ACS foi convidada a participar por ter feito parte do Grupo de Mulheres no momento de sua criação, em 2014. Considerando a mudança de quadro de profissionais da categoria médica, apenas mais uma médica foi convidada a participar devido a sua experiência de mais de 10 anos neste serviço; e ainda, uma enfermeira da parte Tradicional da UBS A" nos concede entrevista, em razão de ter sido enfermeira da ESF nesta mesma UBS e que por sua experiência pode apresentar uma reflexão sobre os modelos de atenção ofertados neste serviço.

Além destes, as duas trabalhadoras do NASF que coordenam o Grupo de Mulheres em parceria com a pesquisadora apresentaram seus percursos formativos, análises e um histórico mais detalhado sobre a constituição do Grupo de Mulheres, bem como as potencialidades e dificuldades de coordenação dessa atividade. E para contextualizar esta experiência no território assistencial, as duas coordenadoras de NASF foram acionadas a fim de apresentar um panorama das estratégias de cuidado direcionadas a mulheres nas UBS do território.

Assim, foram 17 os sujeitos participantes desta pesquisa: duas coordenadoras de NASF, duas profissionais do NASF que coordenam o Grupo de Mulheres em parceria com a pesquisadora, quatro mulheres usuárias da ESF e participantes do Grupo de Mulheres e nove profissionais da UBS A" ${ }^{13}$.

\footnotetext{
${ }^{13}$ As participantes foram informadas sobre os objetivos desta pesquisa e a não-obrigatoriedade de sua participação. Todas assinaram o Termo de Consentimento Livre e Esclarecido (apêndices). O presente estudo foi avaliado e devidamente autorizado pelo Comitê de Ética em Pesquisa da Secretaria Municipal de Saúde do Município de São Paulo, com registro CAAE 57974216.0.3001.0086, parecer 2.026.744 (CEP/SMS) (anexos), emitido em 22/04/2017. Esta pesquisa foi orientada pelos princípios
} 
Considerando a necessidade de obtenção de informações em profundidade para a realização de estudo de caso, foram realizadas entrevistas com os sujeitos da pesquisa, uma vez que "a entrevista é adequada para obter informações acerca do que as pessoas sabem, creem, esperam, sentem ou desejam, pretendem fazer, fazem ou fizeram, bem como acerca das explicações ou razões acerca das coisas precedentes" (Selltiz et al., 1965, apud Gil, 2009, p. 63) ${ }^{14}$. Entrevistas são "conversa com finalidade" (Minayo, 2004, p.99). Os roteiros dessas entrevistas estão disponíveis na seção de Apêndices (B, C, D e E) e o seu conteúdo foi gravado e transcrito.

Outras duas formas de coleta de dados foram propostas no projeto de pesquisa: a observação participante sobre os encontros neste Grupo de Mulheres, e respectivo registro em um diário de campo, e a análise documental de prontuários e atas de reunião, que não foi realizada. Em relação a esta questão é importante ressaltar dois aspectos: a demora para avaliação no Comitê de Ética da Faculdade de Medicina, num total de nove meses, o que nos levou a priorizar as contribuições das entrevistadas e a análise mais aprofundada de seus depoimentos, em vez de um número maior de fontes. O fato do objeto de pesquisa ser devidamente desvelado pelo coletivo, não haveria necessidade de focar nas impressões da pesquisadora sobre o acontecer grupal, uma vez que toda pesquisa já está implicada por suas impressões subjetivas.

Toda a coleta de dados foi realizada pela pesquisadora, considerando-se que "não há pesquisa desinteressada e pesquisador neutro" (Merhy, 2004, p.21), e ainda que

$$
\begin{aligned}
& \text { muitos [trabalhadores] procuram submeter a processos investigativos o seu } \\
& \text { próprio agir, trazendo, com isso, para a análise o seu próprio modo de dar } \\
& \text { sentido ao que é problema a ser investigado, no qual também significa } \\
& \text { claramente a si mesmo a aos outros. Ou seja, traz, antes de qualquer situação } \\
& \text { epistêmica, a sua implicação (Merhy, 2004, p.26). }
\end{aligned}
$$

Trata-se portanto de uma situação complexa em que "você é o pesquisador e o pesquisado [....] Você é um sujeito militante que pretende ser epistêmico e os desenhos de investigação que temos como consagrados no campo das ciências não dão conta deste tipo de processo" (Merhy, 2004, p.22-3).

A análise dos dados se deu através da Análise de Conteúdo - Temática, proposta por Minayo (2004). Em linhas gerais, a Análise de Conteúdo

éticos previstos na Resolução 196/96 do Conselho Nacional de Saúde.

14 Selltiz C, Jahoda M, Deutsch M, Cook SW. Métodos de pesquisa nas relações sociais. São Paulo: Herder; $1965.715 \mathrm{p}$. 
[...] relaciona estruturas semânticas (significantes) com estruturas sociológicas (significados) dos enunciados. Articula a superfície dos textos descrita e analisada com os fatores que determinam suas características: variáveis psicossociais, contexto cultural, contexto e processo de produção da mensagem". A autora afirma que a Análise Temática é uma das modalidades de análise de conteúdo que melhor se adequa à investigação qualitativa do material sobre a Saúde (Minayo, 2004, p.204).

A Análise Temática possui três etapas (Minayo, 2004):

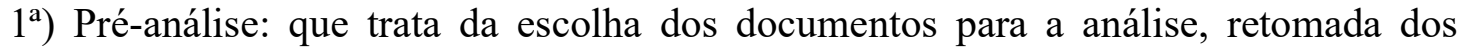
objetivos da pesquisa comparados ao material coletado e elaboração de indicadores que orientam a explanação final.

$2^{a}$ ) Exploração do Material: que consiste na operação de codificação - núcleos de compreensão do texto, realiza a sua contagem, os classifica e os agrega em categorias.

$3^{\text {a) }}$ Tratamento dos Resultados Obtidos e Interpretação: que consiste em submeter os resultados a operações estatísticas, e a partir disto, o pesquisador os relaciona com o quadro teórico previsto ou dá abertura a novas "dimensões teóricas sugeridas pela leitura do material" (Minayo, 2004, p.210).

Reforçamos que o intuito deste projeto não foi gerar previsões estatísticas e nem elaboração de indicadores quantitativos mas sim, apontamentos de temas relevantes a fim de gerar reflexões sobre a prática interprofissional e o cuidado ofertado a mulheres na UBS A".

\subsection{CARACTERIZAÇÃO DO TERRITÓRIO}

Um contexto assistencial é definido pelo território e pelas ações e serviços nele desenvolvidos; sendo assim, este influencia a busca de cuidados pelos usuários. Portanto, se faz necessário o reconhecimento de parte do contexto em que as necessidades de saúde das mulheres, sujeitos desta pesquisa, são reconhecidas, criadas, reproduzidas e transformadas. Um breve panorama sobre a constituição deste território, suas características epidemiológicas e a construção de Rede de Atenção à Saúde (RAS) favorece o reconhecimento de demandas e necessidades de cuidado e de atenção, bem como a compreensão dos percursos trilhados para constituir a assistência no Grupo de Mulheres. 


\subsubsection{Histórico do território e alguns dados sociodemográficos}

A UBS A" localiza-se na Brasilândia, que é um distrito periférico da zona norte de São Paulo - SP, com 264.918 ${ }^{\text {s }}$ mil habitantes (São Paulo (cidade), 2010).

Em 1947, se iniciou o loteamento regular da Brasilândia e seus primeiros moradores residiam em cortiços e moradias populares do centro, demolidos para a construção de avenidas. Nas décadas de 1950 e 1960 a região passa a receber migrantes do nordeste do país e se expande de maneira desordenada através de ocupações de áreas de mananciais (Rosa et al., 2016).

A partir de informações do último censo do Instituto Brasileiro de Geografia e Estatística (IBGE) de 2010, o território da Freguesia do Ó/Brasilândia (FÓ/Bras) possui: 138.495 mulheres, 126.423 homens. A maior concentração de habitantes por faixa etária está entre aqueles com entre 30 e 59 anos (103.065 hab.), sendo seguida da faixa etária de 15 a 29 anos (74.230). A Brasilândia é o segundo distrito da cidade com maior porcentagem de população negra (proporção menor apenas que em relação a Cidade Tiradentes), sendo, entre pretos e pardos, aproximadamente $50,6 \%$ de toda a população do distrito.

Segundo dados do Observatório Cidadão Rede Nossa São Paulo e do Índice Paulista de Vulnerabilidade Social quando se comparam outras informações relativas à Brasilândia em relação ao município de São Paulo (Rosa et al., 2016) observa-se que:

- é o terceiro distrito com maior número de moradores por domicílio (antecedido por Grajaú e Sapopemba);

- é um dos três distritos com pior índice de coleta de lixo (antecedido por Cidade Ademar e São Rafael);

- é um dos quatro distritos com a menor rede de esgoto;

- é o terceiro distrito com a maior porcentagem de domicílios em favelas;

- é um dos piores índices de desigualdade social;

- 40\% dos domicílios possuem renda de até dois salários-mínimos;

\footnotetext{
${ }^{15}$ Dados de 2010. Acesso em 11/06/2016. Disponível em: http://www.prefeitura.sp.gov.br/cidade/ secretarias/subprefeituras/subprefeituras/dados_demograficos/index.php? $\mathrm{p}=12758$.
} 
- do número de empregos formais, 70,6\% são ocupados por brancos, $30,1 \%$ por pardos e $7,83 \%$ por pretos;

- do número de empregos formais, 62,3\% são ocupados por homens;

- está entre os distritos com maiores índices de violência e de homicídio juvenil (atingindo especialmente jovens negros);

- é o sexto dentre todos os distritos com os maiores Índices de Necessidades em Saúde (INS).

Assim, pode-se dizer que a população da Brasilândia é majoritariamente de negros, jovens/adultos e mulheres, o que deve ser apreciado como constitutivo das necessidades de saúde apresentadas (Rosa et al., 2016, p.65-66)

Estes dados, longe de traduzirem toda a condição de vida neste território, apontam questões importantes sobre a vulnerabilidade das pessoas que ali residem e que devem ser consideradas nas propostas de cuidado e de implementação de políticas públicas. Certamente não abrangem as características de toda a produção de vida deste território, mas servem de alerta para que as práticas de saúde não sejam reducionistas e, assim como as dificuldades de um território, as suas potencialidades são fatores de igual importância na constituição dos cuidados em saúde, como destacado pelos autores acima citados:

Território quente, chamado carinhosamente de 'Brasa' por sua população, que se mobiliza, que carrega história de luta, que cobra do Estado garantia de direitos, mas que se organiza, ela própria, para responder a muitas de suas necessidades, o que impõe também importantes desafios no encontro entre os agentes dos serviços públicos estatais e essa população. São muitas as iniciativas culturais, de trabalho e lazer produzidas por atores estratégicos, lideranças dos bairros, por coletivos, associações [....] Mapear os recursos do território, que em muito extrapolam aqueles oferecidos pelo poder público, tem sido um desafio constante, e tem produzido resultados que permanecem ainda muitas vezes distantes do conhecimento e das práticas cotidianas dos serviços de saúde da região (Rosa et al., 2016, p. 66).

A seguir, na figura 3.1 temos um Infográfico com os dados sociodemográficos da Brasilândia comentados acima. 
Figura 3.1 Infográfico da Brasilândia - Dados Sociodemográficos

\section{INFOGRÁFICO DA BRASILÂNDIA - DADOS SOCIODEMOGRÁFICOS}

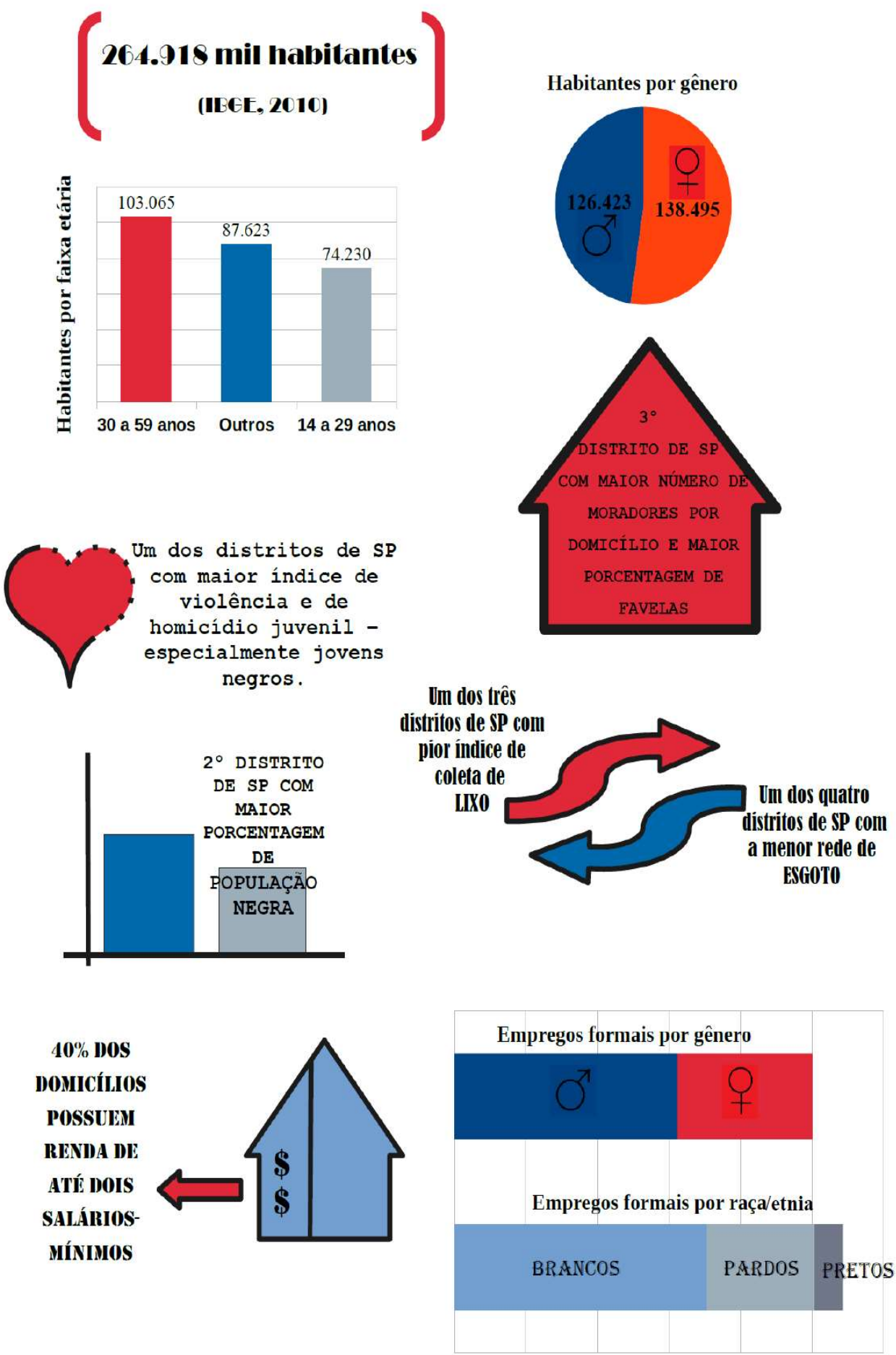




\subsubsection{O desenvolvimento da Rede de Atenção à Saúde (RAS)}

A Supervisão Técnica de Saúde (STS) da FÓ/Bras. recebe o mesmo nome da Subprefeitura, que administra estes dois distritos da cidade de São Paulo: Freguesia do Ó e Brasilândia. A STS FÓ/Bras. é responsável por diversos bairros e serviços de saúde de diferentes complexidades e contratos de gestão entre organizações sociais parceiras e administração direta.

A partir da parceria entre universidade e serviços de saúde, e consequentes projetos de pesquisa e extensão, em 2016 foi publicado o livro "Saúde Mental, Reabilitação e Atenção Básica - Encontros entre Universidade e Serviços de Saúde” (Vicentin et al., 2016). A publicação apresenta resultados e reflexões nos eixos de Saúde Mental e de Saúde da Pessoa com Deficiência/Reabilitação, como também um importante histórico do território e de seus serviços de saúde. Através de depoimentos de moradores e trabalhadores, bem como de trabalhos científicos pregressos, os autores realizam um resgaste desta história e analisam os impactos da descontinuidade das gestões municipais na constituição da RAS. No livro é apresentada também, a importância das gestões estadual e federal para a implementação e manutenção de serviços e seus princípios como a extinção de manicômios e a criação de assistência territorial em saúde mental.

Na década de 1980, quando se inicia a construção da Rede de Saúde, havia um grande número de hospitais psiquiátricos no território (Hospital Pinel, Vera Cruz entre outros.), um Centro de Saúde (gestão estadual) e três Postos de Atendimento Médico (gestão municipal, que com a implementação do SUS e municipalização se tornaram UBSs). Nesta época, o distrito sanitário Nossa Senhora do Ó abrangia as atuais STS FÓ/Brasilândia e STS Pirituba/Jaraguá.

Em parceria com a Secretaria Estadual de Saúde e a disciplina de psiquiatria da Faculdade de Ciências Médicas da Santa Casa de Misericórdia de São Paulo, e com financiamento do INAMPS, foi desenvolvido o "Projeto Zona Norte" que "foi a primeira experiência de assistência integrada e regionalizada em saúde mental na cidade, com um importante engajamento dos profissionais envolvidos" (Ibid., p.35). Este programa promoveu diversas estratégias de regionalização da saúde, entre elas: integração das ações de saúde mental, prevenção das internações psiquiátricas, investimento em ações de formação, proposta 
de implementação de serviços extra-hospitalares para a saúde mental, criação da Unidade de Emergência Psiquiátrica com resgate no Pronto Socorro Geral/Hospital do Mandaqui e do Ambulatório de Saúde Mental da Brasilândia (Andrade et al., 2016).

Em 1986, com a mudança da gestão municipal e, em 1987, a gestão estadual retomou o recadastramento de hospitais psiquiátricos, o que culminou com o fim do "Projeto Zona Norte" e importantes retrocessos nos investimentos da luta antimanicomial do território e do município (Andrade et al., 2016).

No início dos anos de 1990, a nova gestão municipal (Luíza Erundina) retoma ações de descentralização e maior autonomia das regiões da saúde, com valorização do controle social e gestão democrática, territorialização dos serviços de saúde mental e implementação de equipes de saúde mental nas UBSs. Porém, em 1993, a gestão Paulo Maluf introduz o Plano de Assistência à Saúde (PAS), com diretrizes contrárias aos princípios do SUS e um modelo de privatização dos serviços e de contratação dos profissionais da saúde (cooperativas), em que se "optava" ou não pela adesão ao plano. Muitos profissionais não concordantes pedem transferência para outras Secretarias e as UBSs continuaram a prestar atendimento, porém orientadas pelo modelo de queixa/conduta (Andrade et al., 2016).

Em contrapartida, a Secretaria Estadual, em consonância com o Ministério da Saúde, desenvolveu o Projeto Qualidade Integral à Saúde (QUALIS) na cidade de São Paulo com implementação de 55 equipes do Programa de Saúde da Família (PSF) no Distrito de Saúde de Itaquera, em 1996 (QUALIS I/PSF) e em 1997, expande o projeto para as regiões norte e sudeste da cidade (QUALIS II/PSF).

Na Saúde Mental, houve a constituição de equipes volantes (formadas por psicólogos, terapeutas ocupacionais, assistentes sociais e psiquiatras) em três UBSs da STS FÓ/Brasilândia em que eram realizadas discussões de casos e atividades formativas em parceria com as equipes de PSF. É importante ressaltar que a implantação do QUALIS II/PSF neste território começou com a mobilização dos moradores e reuniões para debater a construção do programa. A população sempre esteve presente para reivindicar e se mobilizar na defesa de seus direitos e de políticas sociais para o território (Andrade et al., 2016).

Com a virada do século, a nova gestão municipal (Marta Suplicy) promove o desmonte do PAS e retoma a implementação do SUS com municipalização da saúde, assumindo a coordenação dos serviços até então geridos pelo estado e a Atenção Básica passou a ser responsabilidade do município. Nesta época, a STS FÓ/Brasilândia contava com 
diversos equipamentos de saúde, entre estes, 7 UBSs e 25 equipes de PSF - 14 pelo QUALIS da Fundação Zerbini e 11 pelo QUALIS da Secretaria Estadual. A ampliação do número de equipes de PSF no território, totalizando 45 equipes, se deu em 2001 através de parceria da STS com a ONG Associação Saúde da Família e é neste contexto que a UBS A" recebe 6 equipes de PSF.

No processo de municipalização, acima referido, ressurgiram os Conselhos Gestores, inclusive nas UBSs, foram criados diversos Fóruns de trabalhadores para a condução da política de saúde e as articulações intersetoriais no território e o Ambulatório de Saúde Mental da Brasilândia possibilitaram a fundação do Centro de Atenção Psicossocial II (Andrade et al., 2016). Mesmo com retração dos investimentos na gestão Serra-Kassab, a consolidação destas experiências possibilitou que este trabalho prosseguisse na região. Em 2008, ocorre a criação da Residência Terapêutica masculina e a incorporação dos NASF (inicialmente, 5 equipes); em 2009, o CAPS II Infantojuvenil; e em 2011, o CAPS Ad (que se tornou CAPS III em 2013). No momento de implantação dos NASF, as equipes volantes de Saúde Mental são substituídas pelas equipes multidisciplinares (Andrade et al., 2016), e “o que era um projeto se transformou em política pública” (p.48). 
Quadro 3.2 - Linha do tempo de desenvolvimento da RAS FÓ/Bras. de 1980 a 2011

\begin{tabular}{|c|c|}
\hline Década de 1980: & $\begin{array}{l}\text { Início da construção da Rede de Saúde; havia um grande número de hospitais } \\
\text { psiquiátricos no território, um Centro de Saúde (gestão estadual) e três Postos de } \\
\text { Atendimento Médico (gestão municipal, que se tornaram UBS); } \\
\text { "Projeto Zona Norte"; } \\
\text { Criação da Unidade de Emergência Psiquiátrica com resgate no PS do Mandaqui; } \\
\text { Criação Ambulatório de Saúde Mental da Brasilândia; } \\
\text { Fundação da UBS A" }\end{array}$ \\
\hline 1987: & $\begin{array}{l}\text { A gestão estadual retomou o recadastramento de hospitais psiquiátricos; fim do } \\
\text { "Projeto Zona Norte". }\end{array}$ \\
\hline Anos de 1990: & $\begin{array}{l}\text { Nova gestão municipal retoma ações de descentralização e maior autonomia das } \\
\text { regiões da saúde, implementação de equipes de saúde mental nas UBSs. }\end{array}$ \\
\hline 1993: & $\begin{array}{l}\text { Plano de Assistência à Saúde (PAS), com aspectos contrários aos princípios do SUS e } \\
\text { um modelo de privatização dos serviços e de contratação dos profíssionais da saúde } \\
\text { (cooperativas); } \\
\text { UBSs continuaram a prestar atendimento, porém orientadas pelo modelo de } \\
\text { queixa/conduta. }\end{array}$ \\
\hline 1997: & $\begin{array}{l}\text { QUALIS II/PSF; } \\
\text { Equipes de Saúde Mental volantes em três UBSs da STS FÓ/Brasilândia. }\end{array}$ \\
\hline 2000: & $\begin{array}{l}\text { Desmonte do PAS e retoma a implementação do SUS com municipalização da saúde: } \\
\text { a Atenção Básica passou a ser responsabilidade do município; } \\
\text { A ampliação do número de equipes de PSF no território, totalizando } 45 \text { equipes - } \\
\text { parceria da STS com a ONG Associação Saúde da Família; } \\
\text { Ambulatório de Saúde Mental da Brasilândia tornou-se Centro de Atenção } \\
\text { Psicossocial II. }\end{array}$ \\
\hline 2008: & $\begin{array}{l}\text { Ocorre a criação da Residência Terapêutica masculina e a incorporação dos NASF } \\
\text { (inicialmente, } 5 \text { equipes). }\end{array}$ \\
\hline 2009: & Criação do CAPS II Infanto-juvenil. \\
\hline 2011: & Criação do CAPS Ad (que se tornou CAPS III em 2013). \\
\hline
\end{tabular}

\subsubsection{Composição da rede de serviços de saúde}

Por se tratar de território gerenciado pela mesma supervisão técnica, muitos serviços da Brasilândia são referência para os da Freguesia do Ó, e vice-versa. É importante ressaltar que apesar da localização em uma das duas regiões, os serviços da RAS de ambas atuam articuladamente. 
Os serviços estão localizados nas duas regiões conforme apresentado no quadro 3.3:

Quadro 3.3 - Composição da rede de serviços de saúde do território FÓ/Bras. em $2018^{16}$

\begin{tabular}{|c|c|c|c|c|}
\hline $\begin{array}{l}\text { SERVICCOS DE SAÚDE NO } \\
\text { TERRITÓRIO FÓ/BRAS. }\end{array}$ & SIGLA & $\begin{array}{l}\text { NÚMERO } \\
\text { DE } \\
\text { SERVIÇOS }\end{array}$ & FREGUESIA DO Ó & BRASILÂNDIA \\
\hline Unidade Básica de Saúde & UBS & 14 & 4 & 10 \\
\hline Ambulatório de Especialidades & $\mathrm{AE}$ & 1 & 1 & - \\
\hline Assistência Médica Ambulatorial & AMA & 1 & - & $1^{16}$ \\
\hline $\begin{array}{l}\text { Assistência Médica Ambulatorial / } \\
\text { UBS Integrada }\end{array}$ & $\begin{array}{l}\text { AMA/ } \\
\text { UBS } \\
\text { Integrada }\end{array}$ & 3 & 1 & $2^{16}$ \\
\hline $\begin{array}{l}\text { Centros de Atenção Psicossocial II } \\
\text { adulto }\end{array}$ & CAPS & 1 & - & 1 \\
\hline $\begin{array}{l}\text { Centros de Atenção Psicossocial } \\
\text { III álcool e outras drogas }\end{array}$ & CAPS ad & 1 & - & 1 \\
\hline $\begin{array}{l}\text { Centro de Atenção Psicossocial II } \\
\text { infanto-juvenil }\end{array}$ & CAPS ij & 1 & 1 & - \\
\hline $\begin{array}{l}\text { Centro de Convivência e } \\
\text { Cooperativa }\end{array}$ & CECCO & 1 & 1 & - \\
\hline $\begin{array}{l}\text { Centro Especializado de } \\
\text { Reabilitação II }\end{array}$ & CER II & 1 & 1 & - \\
\hline $\begin{array}{l}\text { Centro de Referência de Saúde do } \\
\text { Trabalhador }\end{array}$ & CRST & 1 & 1 & - \\
\hline Centro de Referência DST/AIDS & $\begin{array}{l}\text { CR DST/ } \\
\text { AIDS }\end{array}$ & 1 & 1 & - \\
\hline Centro de Saúde Bucal II & CEO II & 1 & - & 1 \\
\hline Laboratório & - & 1 & 1 & - \\
\hline Núcleo Integrado de Reabilitação & NIR & 2 & 1 & 1 \\
\hline Pronto-Socorro & PS & 1 & 1 & - \\
\hline Serviço da Rede Hora Certa & HDRHC & 1 & - & 1 \\
\hline
\end{tabular}

${ }^{16}$ Um destes serviços localiza-se no território de abrangência da UBA A", e está incorporando gradativamente 4 equipes de Estratégia de Saúde da Família, desde abril de 2018. Porém, continuará com atendimentos a demanda espontânea em modelo de Posto Avançado, com pediatria e clínica geral, mantendo-se aberta aos sábados. Segundo informações da gerente da UBS A", sua unidade é atualmente responsável pela população que será atendida por esta nova UBS. As 4 novas equipes de SF abarcarão no máximo 16.000 pessoas, de um bairro com 42.000, assim, 22.000 ainda seriam responsabilidade sanitária da UBS A", no modelo tradicional. Este novo serviço de AB não receberá apoio matricial de equipe NASF. 
Na figura 3.4 está apresentada a distribuição dos serviços de saúde e a localização da UBS A".

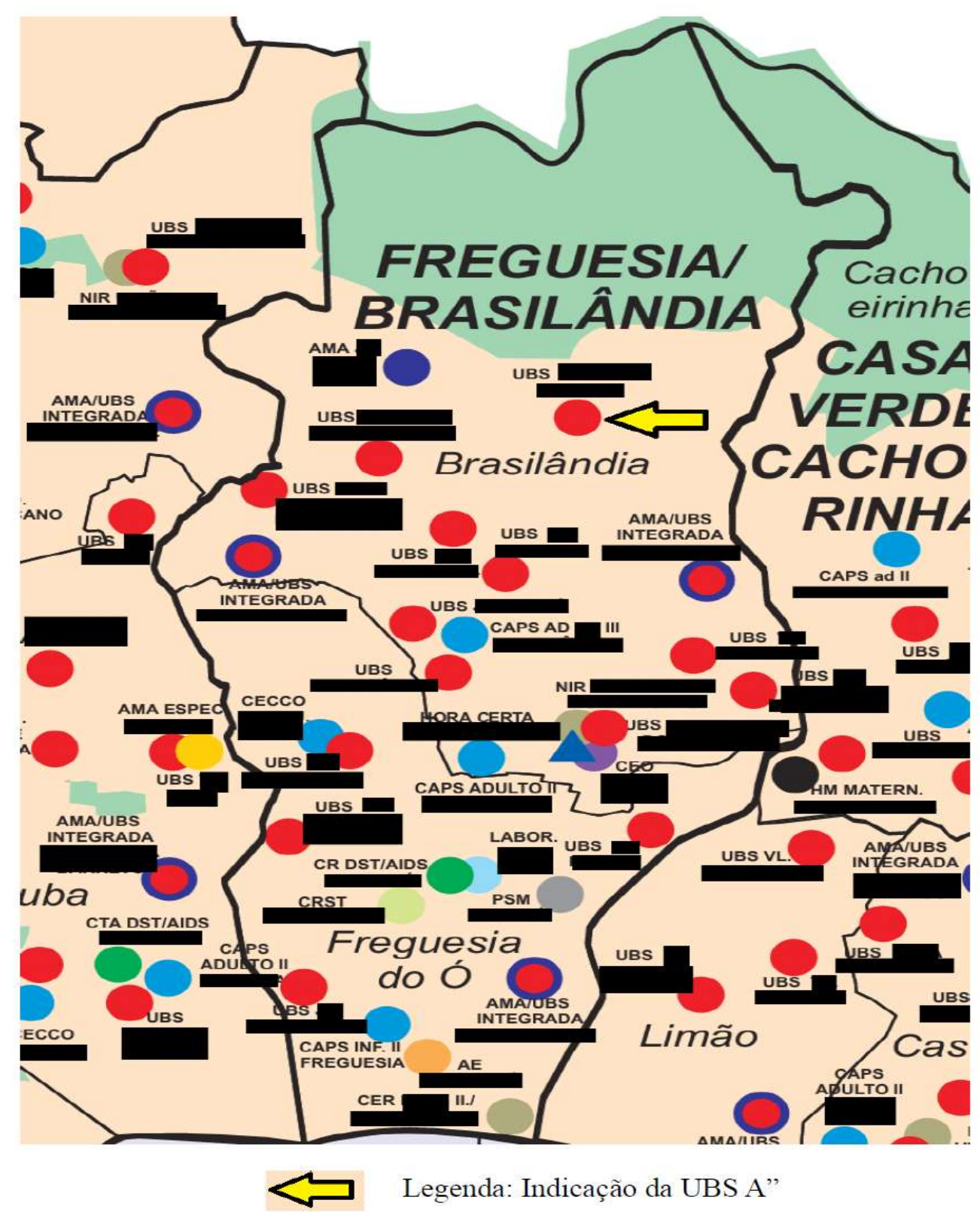

Fonte: Mapa das Unidades de Saúde de Rede Municipal por Coordenadoria Regional de Saúde e Subprefeitura do Município de São Paulo. São Paulo: Secretaria Municipal de Saúde. [Internet] [citado 09 de mai.2018]. Disponível em: http://www.prefeitura.sp.gov.br/cidade/secretarias/saude/ epidemiologia_e_informacao/producao_e_rede_assistencial index.php?p=30566. 


\subsubsection{Caracterização da UBS A"}

A UBS A" foi fundada no ano de 1982 como uma UBS Tradicional, isto é, não desenvolvia ESF. Seu crescimento ocorreu gradativamente, de acordo com a necessidade da comunidade - inicialmente eram de 300 a 500 atendimentos por mês e hoje são em torno de 1000 por dia e o número de funcionários passou de 27 para 142 (incluindo funcionários da limpeza, da vigilância, da odontologia e do NASF). Essa ampliação implicou na adesão a programas ministeriais: em 2002, ao Programa de Agentes Comunitários de Saúde (PACS) e em 2008, à ESF com 6 equipes. Com a cobertura de apenas 14\% da população, a UBS passou a funcionar como Unidade Mista, mantendo o modelo de Unidade Tradicional para o restante da população. Em 2009, recebeu algumas médicas da Assistência Médica Ambulatorial (AMA) do território, caracterizando-se também um serviço de Posto Avançado. Em 2010, houve a chegada do NASF para o apoio matricial às equipes da ESF. E em 2015, houve a chegada da equipe de Odontologia.

Trata-se portanto, de uma UBS Integrada (gestão da prefeitura municipal de 20122016), com aproximadamente 80.000 usuários em um território amplo e muito vulnerável, que abrange cinco bairros diferentes (são 60.000 prontuários individuais ativos da UBS tradicional e 3.800 prontuários de família da ESF, totalizando 19.000 pessoas) (informação verbal $^{17}$ ). De acordo com a legislação ministerial, seriam necessárias duas UBS para o cuidado de toda esta população (35.000 por UBS e 4.000 pessoas por equipe de ESFis).

Assim, em março de 2018, o antigo AMA do território foi transformado em UBS de ESF, com 4 equipes de SF, o que diminui em 16.000 usuários a responsabilidade sanitária da UBS A”. Na figura 3.5, apresentamos o desenvolvimento da UBS A”.

\footnotetext{
${ }^{17}$ Foram duas gerentes consultadas: a primeira saiu do cargo em dezembro/2015 e a segunda assumiu em janeiro/2016. As informações foram fornecidas principalmente pela primeira gerente, no dia 12/12/13, e obtidas a partir das anotações pessoais da pesquisadora, que na ocasião era preceptora do PET Saúde - Redes de Atenção e fazia uma entrevista sobre o histórico da UBS A" junto aos alunos. A outra oportunidade de consulta foi em 07/06/16, já com a segunda gerente.

${ }^{18}$ Dados da ESF. [Internet] [citado 10 de out.2016]. Disponível em:

$\mathrm{http} / / /$ dab.saude.gov.br/portaldab/smp_como_funciona.php.conteudo=esf.
} 
Figura 3.5 - Linha do tempo do desenvolvimento da UBS A”

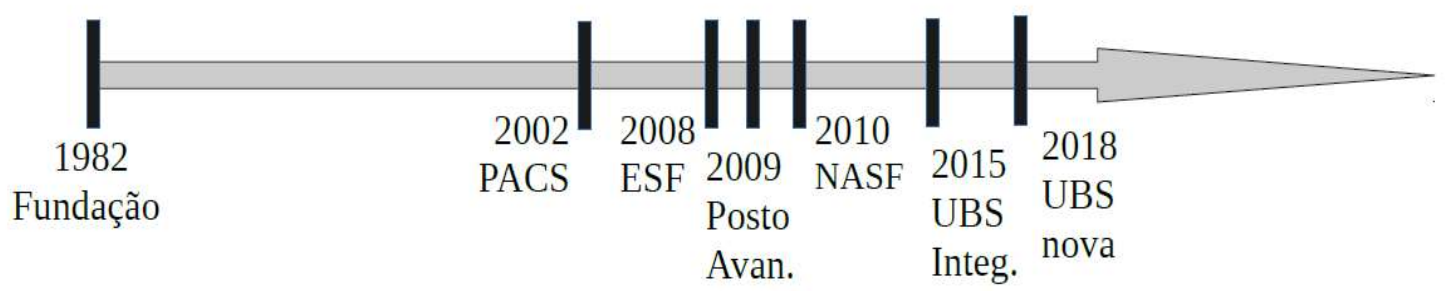

\subsubsection{As equipes de Núcleo de Apoio à Saúde da Família (NASF) do território}

O território da FÓ/Bras. conta com cinco equipes de NASF 1. As contratações das profissionais de NASF acontecem através de processos seletivos e são realizadas pela Organização Social da Saúde (OSS) que administra a maioria dos serviços de saúde dessa STS, em parceria com a SMS/SP. Cada equipe de NASF apoia um determinado número de equipes da ESF divididas em mais de uma UBS, sendo apenas uma das UBS registrada como sede administrativa.

A formatação das equipes de NASF e respectivas equipes de ESF estão esquematizadas na tabela 3.6. 
Tabela 3.6 - Número de equipes de ESF apoiadas pelos NASF do território da Brasilândia

\begin{tabular}{cccc}
\hline UBS & $\begin{array}{c}\text { NÚMERO DE } \\
\text { EQUIPES DE ESF }\end{array}$ & $\begin{array}{c}\text { EQUIPE DE } \\
\text { APOIO - NASF }\end{array}$ & $\begin{array}{c}\text { TOTAL DE EQUIPES } \\
\text { APOIADAS PELO NASF }\end{array}$ \\
\hline UBS A' & 7 & NASF A & 13 \\
UBS A" & 6 & & 12 \\
UBS B' & 7 & NASF B & 12 \\
UBS B" & 5 & & \\
UBS C' & 7 & NASF C & 15 \\
UBS C" & 5 & & \\
UBS D' & 5 & NASF D & \\
UBS D" & 6 & & \\
UBS D"” & 4 & & \\
UBS E' & 5 & NASF E & \\
\hline UBS E" & 7 & & \\
UBS E'” & 4 & 68 & TOTAL \\
\hline TOTAL & & & \\
\hline
\end{tabular}

De acordo com a portaria 3124/MS de 2012, em número absoluto de equipes de SF, seriam necessárias mais duas equipes NASF na região da Brasilândia, considerando o mínimo de cinco e o máximo de nove equipes de SF apoiado por NASF:

68 equipes de $S F / 9$ (máximo de equipes de $S F$ por $N A S F)=7,55$ 
Porém, cada UBS tem número fixo de equipes de SF, que não podem ser distribuídas para que cada NASF opere em seu máximo de carga horária. Assim, a composição das UBS por NASF deve ocorrer com soma total de no máximo nove equipes de SF. Portanto, seria necessário duplicar o número atual de equipes NASF, somente na Brasilândia, o que somaria 5 novas equipes NASF.

Tabela 3.7 - Número de equipes NASF necessárias no território da Brasilândia

\begin{tabular}{ccc}
\hline UBS & $\begin{array}{c}\text { NÚMERO DE } \\
\text { EQUIPES DE ESF }\end{array}$ & $\begin{array}{r}\text { NOVA PROPOSTA DE EQUIPES NASF } \\
\text { (5 a 9 equipes de SF apoiadas) }\end{array}$ \\
\hline UBS A' & 7 & NASF 1 \\
UBS A" & 6 & NASF 2 \\
UBS B' & 7 & NASF 3 \\
UBS B" & 5 & NASF 4 \\
UBS C' & 7 & NASF 5 \\
UBS C" & 5 & NASF 6 \\
UBS D' & 5 & NASF 7 \\
UBS D" & 6 & NASF 8 \\
UBS D"” & 4 & NASF 9 \\
UBS E' & 5 & NASF 10 \\
UBS E"” & 4 & NASF 11 \\
UBS E" & 7 & 11 \\
\hline TOTAL & 68 & \\
\hline
\end{tabular}

Sendo assim, seria necessário no mínimo 40 profissionais a serem contratadas, ou seja, aproximadamente sete por nova equipe NASF, através de um cálculo em que consideramos:

- as categorias que são tradicionalmente contratadas pela OSS em acordo com o contrato de gestão: 3 possibilidades de profissionais 40 horas - fonoaudióloga, 
nutricionista e psicóloga; 1 possibilidade de profissional 30 horas - assistente social; 5 possibilidades de profissionais 20 horas - fisioterapeuta, TO, pediatra, psiquiatra, ginecologista e acupunturista;

- o mínimo da carga horária autorizada para implementação de uma equipe NASF (200 horas);

- os menores gastos, uma vez que os salários não são equiparados por número de horas (médicos 20 horas, seguidos de fisioterapeuta e TO recebem, proporcionalmente, maior salário que profissionais 40 horas, por exemplo).

As equipes de NASF1 do território estão organizadas com carga horária total mínima de aproximadamente 200 horas e, ainda em 2018, estão em desacordo com a portaria 3124/MS de 2012, que prevê apoio matricial a no máximo nove equipes de SF. Este território e o território vizinho, da STS Casa Verde/Cachoeirinha/Limão, são os únicos da Coordenadoria Regional de Saúde Norte $^{19}$ (responsável por cinco STS) que estão em desacordo com a referida portaria.

Esses cálculos simples evidenciam o descompasso entre o previsto pela política e a realidade dos serviços deste território, o que implica diretamente nas possibilidades de apoio a ser prestado às equipes de SF e na assistência à população. Considerando-se ainda a proposta de mudança de paradigma incutida ao NASF, restam dúvidas sobre a eficácia colocada para o trabalho, visto que há poucas profissionais representantes da lógica do apoio matricial em contato com as equipes apoiadas.

\subsection{APRESENTAÇÃO E ANÁLISE DOS DADOS RELACIONADOS AO TRABALHO DE} CAMPO

Considerando a Análise Temática proposta por Minayo (2004), ressaltamos que o processo de análise de dados, assim como a pesquisa como um todo, não se deu por fases e tarefas perfeitamente delimitadas no tempo. Desta forma, as etapas da pesquisa indicadas

\footnotetext{
${ }^{19}$ O município de São Paulo - SP possui 5 coordenadorias regionais de saúde, sob a responsabilidade da Secretaria Municipal de Saúde (SMS/SP). Em 2014, a STS FÓ/Bras. apresentava um total de 2570 funcionários, sendo 1578 funcionários $(61,4 \%)$ sob supervisão de empresas parceiras. Acesso em 24/04/2018. Disponível em: http://www.prefeitura.sp.gov.br/cidade/secretarias/saude/cogep/ coord_norte/organizacao/index.php? $\mathrm{p}=152371$
} 
anteriormente foram simultâneas. Portanto, a sistematização apresentada a seguir é uma tentativa de facilitar a compreensão do leitor.

\subsubsection{Análise e discussão das categorias empíricas}

No primeiro contato com o material das transcrições, foram elencadas cinco categorias que representam as temáticas mais prevalentes colocadas pelas entrevistadas, que dialogam com a literatura científica:

1. Gênero: o papel e o peso de ser mulher e a influência na saúde, "o que é ser mulher, nessa sociedade, nesse bairro" (E4) ${ }^{20}$, vida pessoal, empatia, gênero como algo cultural e que influencia a maneira de criar meninos e meninas, inclusive no sentido de afirmar que as mulheres se cuidam mais que os homens.

2. Ofertas de cuidado: são apresentadas e divididas em estratégias relacionadas à dimensão biológica (papanicolau) e à dimensão emocional (escuta). As entrevistadas apresentam os espaços direcionados para a Saúde da Mulher na UBS e seus limites e potencialidades como o acesso (maior acesso a gestantes), a integralidade (a mulher como um todo) e o vínculo (essencial para a eficácia das ações de cuidado).

3. Grupo de Mulheres: a relação do trabalhador com o grupo, seu funcionamento, população-alvo, dificuldades (pouca divulgação e falta de esclarecimento sobre o funcionamento) e objetivos (o empoderamento das mulheres).

4. Necessidades de saúde: a "fama" da UBS A" (muito difícil de trabalhar, população muito grande), conceito de Saúde da Mulher, necessidades de saúde das mulheres do território, baliza entre as ofertas de cuidado e as necessidades das mulheres.

5. Formação profissional: a escolha do curso, percursos de formação, empregos, dificuldades no cuidado às mulheres (população muito grande, formação estritamente biológica) e sugestões para lidar com tais dificuldades.

\footnotetext{
${ }^{20}$ Os sujeitos da pesquisa serão identificados em três grupos: grupo $\mathrm{E}$ - trabalhadoras da UBS A" (E1, E2, E3, E4, E5, E6, E7, E8 e E9); grupo N - trabalhadoras do NASF (N1, N2, N3 e N4); grupo M usuárias participantes do Grupo de Mulheres (M1, M2, M3 e M4).
} 
Em seguida, foi realizada a codificação em núcleos de compreensão do texto que, através de sua contagem por frequência e pertinência de acordo com a literatura, foram agregados em quatro categorias empíricas:

- Gênero como potencial de desgaste e de fortalecimento;

- Escuta reconhecida pelas trabalhadoras como demanda das mulheres;

- Empoderamento das mulheres como objetivo do Grupo de Mulheres;

- Grupo de Mulheres como estratégia de cuidado às necessidades ampliadas de saúde.

As categorias empíricas serão apresentadas a seguir com excertos das transcrições das entrevistas, seguida de Análise e Discussão.

\subsubsection{Gênero como potencial de desgaste e de fortalecimento}

De acordo com as trabalhadoras entrevistadas, a população atendida pela UBS A" é uma comunidade que lida cotidianamente com a violência de gênero, principalmente, a violência doméstica.

O papa nicolau, nem é tão importante perto de todas as situações que ela [mulher] vivencia, muitas situações de violência, de baixa autoestima [...] Eu falava de DST, de DST, mas assim, a mulher era violentada pelo próprio marido em casa, e aí assim, que poder ela tinha de decisão, na escolha de usar ou não o preservativo, por exemplo, né, enfim, o buraco era mais embaixo, e a gente acabava ficando sempre ali na superfície, né, da DST. (E1)

E aí, uma coisa que aparece nesse momento [papanicolau] é: relações violentas, inclusive por familiares, violência sexual, e aí, a gente acaba pegando essas coisas, não sei, até quando você vai atender e você vê uma coisa estranha, você fala: 'nossa o que é isso?' (E4)

Assim, essas trabalhadoras identificam que na menor oportunidade de assistência às necessidades de saúde restritas (papanicolau, por exemplo), as mulheres que buscam a UBS A" abordam também as suas necessidades ampliadas de saúde.

Um papanicolau nunca é só um papanicolau. É um papanicolau com uma escuta [...] É terapêutico. Porque tem muitas que vai lá conversar com a gente e ela [mulher] acaba desabafando muita coisa, falando muita coisa, até coisa de filhos [...] todos os espaços que elas têm, que elas podem falar alguma coisa, elas sempre vêm, mas é meio restrito o horário pra isso, é mais 
no papa mesmo que a gente consegue, ou na consulta da criança $[\ldots]$ geralmente o pai nunca vem junto. (E2)

Ao se deparar com as necessidades de saúde ampliadas, as profissionais têm dificuldade de reconhecer em sua prática uma maneira de ofertar cuidado. Ainda temem que, se realizarem um processo de maior problematização da realidade, as usuárias venham a se sentir piores e até sofrerem mais violência em casa ao confrontarem seus companheiros. Diante da complexidade das necessidades de saúde, as trabalhadoras se defrontam com a limitação de sua prática, o que muito as angustia.

'Olha, você está sofrendo', porque a partir do momento que ela [mulher] cria consciência do sofrimento, o sofrimento é maior assim, e o que ela vai fazer com isso, que outras ferramentas eu dou pra essa mulher? Então eu acho que muitas vezes isso me paralisou assim, como profissional, sabe: 'oh, você apanha todo dia', mas é uma situação tão miserável que ela não tem nenhuma outra ferramenta de, né, ela não tem nenhum outro apoio do lado dela, e se ela tomar consciência dessa situação assim, o que ela vai fazer com isso né? $\mathrm{E}$ de eu me sentir responsável, sabe, de em algum momento eu estimular uma mulher a denunciar, por exemplo, uma questão de violência e ela ser morta, porque ao mesmo tempo, a gente não tem a segurança. (E1)

A gente está num território e eu não sei qual seria a reação desse homem, se ele iria aceitar ou se ele iria ficar bravo, e ia querer, não sei, teria que apontar de uma forma muito delicada, não sei, eu até teria [coragem], mas de uma forma muito sutil. (E3)

As profissionais compreendem que para além da violência de gênero, há também grande ausência do Estado neste território. As famílias vivem, em sua maioria, em situação de intensa vulnerabilidade social.

Eu atendo pessoas que às vezes eu chego e não tem água encanada, não tem eletricidade, mora em condições muito piores, situações de violência extrema, então assim, a situação é muito pior, eu precisaria de muito mais monitoramento. (E1)

E aqui hoje elas têm muito problema com o filho né, que a maioria não trabalha, não tem assim uma atividade. (E5)

Uma usuária (M1) apresenta o seu desejo de completar os estudos e problematiza o fato de suas irmãs não terem terminado a escola e que isso lhes acarretou a condição de terem "empregos ruins". Uma delas inclusive, participa de um grupo de fisioterapia na UBS m razão de dores crônicas.

É bom pra você aprender, arrumar um serviço bom [...] as minhas irmãs são tudo faxineira $[\ldots]$ elas só ficam reclamando dos patrões [...] mexer com computador [um bom emprego] e não ficar limpando a casa das pessoas, que tem umas pessoas que são muito chata. (M1) 
Este fato também é problematizado na seguinte fala de uma trabalhadora:

Acho que acaba repercutindo muito na saúde mental. Por ser um bairro mais vulnerável, o comum de trabalho delas [mulheres] é mais na limpeza, trabalhos mais pesados, que acabam tendo uma repercussão no corpo, mas acho que o que fica mais é a saúde mental, de desgaste, de estresse, com filhos. Muitas falam 'ai eu gritei, mas eu não queria, sabe assim, mas eu estou cansada, eu não aguento mais' Eu acho que o trabalho tem um peso muito grande e talvez as relações na residência, que eu percebo que são muito opressoras. Então, refletir, pensar, acho que ajuda. (E4)

As falas acima apresentadas poderiam ser sintetizadas como "o peso que a mulher carrega", um conceito apresentado por E3, e recorrente em diversas entrevistas.

A grande maioria [das mulheres] não consegue sair desse 'peso que a mulher carrega' de ser a responsável pela maioria das obrigações, das funções com os filhos, da casa, e de trabalhar também. E isso não é cuidado porque mesmo as mulheres não percebem assim. (E3)

Elas [mulheres] sofrem abuso, sofrem maus-tratos e se sentem na obrigação de ser mãe, de limpar, lavar e passar e agradecer ainda aquele homem que está dentro de casa, e faz tudo isso. (E2)

São mulheres que estão em casa, que tem os problemas já com o marido, tem problemas com o filho, elas têm uma sobrecarga muito grande. (E5)

A gente ainda cria as mulheres pra serem assim né, pra elas serem responsáveis, isso ainda está muito enraizado, de como você cria menina e de como você cria menino, né? (E6)

Infelizmente ainda a mulher tem a maior sobrecarga do trabalho, entendeu, tem que cuidar do filho, tem que fazer janta, então isso também atrapalha. (E9)

As mulheres vão acumulando muitas coisas, é o trabalho fora de casa, é o trabalho dentro de casa, é cuidar dos filhos, né, e pouco momento de cuidado pra si, né, e que daí é inevitável que uma hora isso não vai, que esse equilíbrio não vai se manter assim. E alguma coisa aí vai romper, e daí eu não sei, eu percebo muito isso, muito adoecimento nesse sentido mais circunstancial da vida assim, né, de muita sobrecarga e de pouco tempo de cuidado, reflexão. E daí, muita gente acaba fazendo uso de medicação, é, sem precisar fazer, porque não é isso, talvez a medicação seja necessária por um tempo, mas você precisa rever a sua vida, e daí eu não sei, o quanto de fato os serviços proporcionam isso né. Você já entra numa coisa de, ah, de medicalizar o sofrimento. (N3)

É importante ressaltar que "o peso que a mulher carrega" depende muito da sua condição de vida.

Coisas que pra gente é muito claro e pras mulheres não pareciam ser, e às vezes, a gente não precisa dizer que é, mas quando a gente discute, e pensa junto, coletivamente, acaba surgindo essas questões mesmo. Então, acho que uma problematização do que é ser mulher, nessa sociedade, nesse bairro. 
Nem todas [as mulheres] têm as mesmas características, nem todas as pacientes manifestam os mesmos sintomas [...] Não é o mesmo uma mulher que mora aqui na periferia e uma mulher que mora numa outra cidade, não tem as mesmas chances, as mesmas oportunidades. (E9)

Eu nunca vi uma mulher aqui, uma puérpera com as mesmas queixas que eu tive. (E1)

Neste contexto de vulnerabilidade social, ausência de Estado e dificuldade de acesso a bens e serviços, "ser mãe" pode ser o projeto de vida de muitas mulheres, muitas delas ainda adolescentes.

A primeira [mãe] que eu vi que falou: 'agora ela [filha] engravidou porque ela quis, porque ela e o namoradinho quiseram, eles não vão morar, mas eles chegaram e conversaram com a gente': 'mãe, quero ter um filho', 'mas filha você tem 18 anos, e quantos anos ele tem?', '21', só que a gente quer, e a gente não vai morar junto mãe'. Isso ela me contando na consulta. Entendeu? Mas é uma outra coisa, foi uma opção deles, teve a participação da família. (E5)

Se é um exame [gravidez] que deu negativo, eu acho que a gente teria que chamar pra um atendimento, também: porque você quer, você veio fazer o teste, mas você queria que desse positivo? Você não acha que está muita nova? Ou então, conversa: porque que você não está evitando? (E8)

Estas profissionais (E5 e E8) entendem que a falta de informação e acesso ao serviço de saúde influenciam muito o grande número de gestantes, inclusive de adolescentes gestantes, no território.

[Falta] o passo a passo da gestação na adolescência, porque hoje o nosso número de adolescentes aqui é muito grande, entendeu. De 13 a 25 anos aumentou muito [...] não é só informação o que falta pra elas não engravidarem, mas eu acho já é o primeiro passo, né, eu acho que falta um pouquinho de conhecimento. (E5)

A gente tem vários ginecologistas mas que atendem praticamente pré-natal: 600 gestantes! Onde que elas [mulheres não gestantes] vão pegar o anticoncepcional? (E8)

Porém, no referido contexto, ser gestante pode ser um potencial de fortalecimento para estas mulheres, tanto no serviço de saúde quanto na vida pessoal.

Tem questões que não aparecem a vida toda, vão aparecer na gestação, até porque a gestação é o momento que elas estão sendo prioridade, estão tendo momentos de consulta [...] tem pouco acesso pra mulher que não é gestante. Não é que as coisas aparecem na gestação [...] o acesso é mais fácil pra gestante [...] a gente vai dando atenção pras prioridades, porque é mais cobrado. (E3) 
Na unidade elas têm uma sala, que é o 'Mãe Paulistana', né. Elas têm preferências no atendimento, elas têm uma atenção, elas não vêm, a gente liga, a gente vai atrás, eu acho que é diferente. Nesse sentido, a gente acaba protegendo, enfim, é um reflexo [...] pra elas terem atenção nessa unidade, elas têm que estar grávidas! [...] é uma prioridade da atenção básica, porque a gente entende os riscos [...] elas têm um empoderamento quando elas estão gestantes. A maior parte delas, muitas param de apanhar quando estão gestantes [....] muitas, às vezes, têm outros privilégios que não têm quando não estão gestantes, até dentro do próprio núcleo familiar [...] ser gestante numa comunidade é uma forma de ganhar uma proteção, né, que traz uma tranquilidade. (E1)

3.3.1.2 Escuta reconhecida pelas trabalhadoras como demanda das mulheres

Uma das questões das entrevistas aborda as necessidades de saúde que as mulheres, usuárias da UBS A" apresentam. E de formas variadas, a maioria das trabalhadoras compreendem que as mulheres vão à UBS A" em busca de escuta, mesmo que, em primeira instância, sejam apresentados sintomas físicos.

Escuta, sempre, escuta. A maioria, acho que $50 \%$ das pessoas não são doentes, de doenças mesmo, eles são carentes de escuta. (E2)

Elas buscam muito acolhimento na unidade por outras questões da vida, e aí a gente acaba sempre escutando muito, então eu acho que hoje em dia, eu acho que é uma das questões que eu valorizo muito, que é o acolhimento de uma mulher que está em sofrimento. (E1)

Eu vou em visita e vou ouvir quem está em sofrimento. E, agora mesmo, as mulheres que vêm e que procuram, eu acho que nós somos pouco acessíveis, também, mesmo se eu estou disponível, eu acho que eu escuto essa mulher, mas parece que é aquela escuta olhando no relógio. E eventualmente eu vou estar escutando totalmente disponível pra aquele momento assim pra ela. (E3)

Apenas uma das quatro usuárias coloca a escuta como sua necessidade, mais conectada com um sofrimento psíquico.

Querer conversar, no caso, com terapeuta, pra conversar pra melhorar o meu estado atual, que eu ando meio depressiva. (M2)

Algumas profissionais compreendem que a escuta seja uma estratégia direcionada aos cuidados em saúde mental, portanto, parecem associar qualquer tipo de sofrimento a quadros de sintomas diagnosticáveis. 
Eu acho que os problemas de depressão que as mulheres têm, é que, eu acho que, se tivesse assim, como eu posso dizer, mais tempo pra gente escutar, ou algum, sei lá, grupos pra conversar, eu acho que resolvia também um pouco. (E5)

E da parte emocional, o que eu faço é nas visitas domiciliares, eu não saio em visita pra isso, mas durante as visitas, que às vezes eu saio pra visita sem ter uma casa marcada pra ir [...] o cuidado que eu tenho é se aparecer durante essas visitas, uma conversa, aí de repente agendo uma outra visita, ou um atendimento aqui, ou trago pra vocês (NASF), e, mas, a questão emocional é tratada dessa forma. (E3)

Assim, sendo a escuta considerada como estratégia específica de cuidados em saúde mental e o Grupo de Mulheres, reconhecido como espaço para tal, parece haver certo receio em ampliar a escuta, que é direcionada a esta atividade.

É muito difícil instituir um grupo na unidade. Acho que demora muito até o negócio engrenar, e encaminhar essas pessoas pra uma escuta, porque eu encaminho bastante, não sei se chegam todas [...] grupo [de Mulheres] supriu o que elas estavam precisando assim, esse espaço de escuta. (E1)

Outras profissionais já compreendem que a escuta seja uma maneira de aprofundar as questões, transformar as demandas em necessidades ampliadas de saúde, que são muito complexas.

Primeiro ouvir pra poder saber como fazer aquele acolhimento, né, estudar assim, o perfil de cada uma, as necessidades, pra se atingir um objetivo. Eu acho que não tem uma estratégia definida, eu acho que as coisas vão surgindo. (E7)

Muito acima de um atendimento médico, é conseguir ouvir, tem que valorizar a ela como pessoa, está dentro desta categoria, pra ela sentir que tem um espaço. Mas uma consulta não dá, não alcança o tempo. (E9)

Nos meus grupos, nas minhas conversas, eu passei a trazer mais as questões voltadas pra autoestima, né, um espaço de fala e escuta, porque muitas vezes elas têm vergonha, se sentem culpadas. (E1)

Acho que só o fato de você escutar ali já ajuda né? [...] Porque a gente cria esse vínculo de vir conversar, mas, ao mesmo tempo, você vai fazer o quê? Assim, né, você vai ouvir, mas quando você vai tirar o filho dela da rua, ali? (E5)

Há profissionais que identificam a falta de tempo como principal fator de inviabilização de uma escuta mais aprofundada.

É isso que falta aqui, um momento pra gente escutar mais. A gente tem os grupos, tem. Mas eu acho que é mais um momento que elas têm de conversar com a gente assim, sozinha [...] Eu amo colher papa. Mas porque? Pelas histórias, entendeu. Colher os dados. (E5) 
Acho que seria uma coisa interessante se pudesse ter um tempo maior pra escutar essa mulher, porque às vezes, não é só a questão física. (N1)

Outras profissionais compreendem que além dos arranjos do processo de trabalho, há profissionais que não são formadas para uma ampliação da escuta, e ainda, que para além da formação profissional, esta abordagem se relaciona com a visão de mundo daquele profissional.

Tem profissional que é mais disponível e é aberto pra ouvir essas situações, outros não, outros dão jeito de cortar a conversa logo no começo. (E3)

Não me importa se é saúde da mulher, do homem, da criança, não importa, pra mim não tem esse recorte. Todos são tão importantes quanto qualquer outro, e todos devem ser ouvidos na sua singularidade, na sua especificidade, tem que ter escuta pra isso [...] eu acho que a gente não pode perder a escuta, porque a queixa vem, do jeito que vier [...] A pessoa chegou até você, se ela chegou até você, como é que você utiliza esta possibilidade da melhor forma que você puder pra disponibilizar possibilidades de encontros [...] gostaria de olhar mais pro perfil do profissional. (N4)

Por fim, a falta de escuta é apresentada como um fator de adoecimento das mulheres deste território.

As mulheres aqui neste território elas têm pouco espaço de escuta né, é pouco, parece que elas não têm direito de sofrer, elas não param, têm que tocar a vida, tem que ser forte. (E1)

[O adoecimento das mulheres] tem a ver mesmo com essa sobrecarga, com a pouca possibilidade de diálogo e de escuta. (N3)

Porém, N2 compreende que mais do que um simples desabafo, como apresentado por muitas profissionais, ter escuta significa ter reconhecimento, o que parece ser a "real" necessidade destas mulheres, que também não encontram espaço nesta UBS A".

Muitas mulheres do nosso território [....] não têm voz ativa, não têm espaço, não têm direito, não têm escuta. E aí eu acho que por conta disso, um intenso sofrimento, que a gente foi vendo na nossa população [....] acho que até existem alguns acolhimentos, acho que tem uma escuta, mas trabalhar isso, não. (N2)

\subsubsection{Empoderamento das mulheres como objetivo do Grupo de Mulheres}


Ao serem convidadas a refletir sobre o funcionamento do Grupo de Mulheres, três profissionais nomeiam como objetivo desta estratégia, o empoderamento das mulheres. Porém, E2 apresenta uma compreensão diferente de outras entrevistadas, E4 e E7.

Eu acho que é um grupo encorajador mesmo, um grupo de empoderamento [...] um grupo que ensina a mulher a ter mais força [...] um grupo que dá oportunidade de uma mulher ficar em frente a outra, é, comparando as suas problemáticas. Saber que ela não está sozinha, que muitas mulheres estão na mesma situação [...] Mais empoderadas, têm mais autonomia, ou, como eu posso usar essa palavra, têm uma visão mais ampla. Falam assim: nossa, eu não enxergava isso, hoje eu já enxergo de uma outra maneira, hoje eu consigo lidar melhor com os meus conflitos. Não porque alguém me ensinou, mas eu consegui enxergar com a própria experiência, com a conversa. (E7)

Eu acho que [o que espero do grupo] empoderar as mulheres [...] ter mais força, de se reconhecer mais, de se perceber como mulher e as questões que envolvem tudo isso. Então, pra que a mulher consiga ter um embate maior, seja na vida, no trabalho, em casa. (E4)

Pra elas terem esse negócio de se empoderar de verdade, e conseguir se arrumar, sabe, ter essa parte, porque toda mulher tem um lado feminino que quer mostrar. Por mais tímida que seja, ela quer aprender a fazer alguma coisa né, e aqui a gente acaba fazendo mais escuta e conversando na parte mais psicológica né, não é de falar: vamos ter uma oficina pra fazer uma roupinha, uma blusinha pra você. (E2)

Outras profissionais abordam o mesmo tema, porém, sem nomear como “empoderamento", e da mesma forma, é possível notar diferentes percepções sobre este conceito.

Acho que elas [mulheres] vão ficando tão autossuficientes aí elas nem me procuram mais. (E1)

Basicamente [o grupo serve] para fortalecer o papel dela, para enfrentar e ouvir outros critérios como as demais enfrentam um problema determinado e ajudam ela a enfrentar o seu. São condutas aprendidas, tanto pela experiência de outras mulheres como pelas orientações do próprio profissional. Têm aceitação e mudam e têm um jeito diferente de enfrentar o problema; que ela consiga melhor qualidade de vida, que elas consigam superar o problema, se tiverem. Ou pelo menos, aumentar o nível de tolerância a frustrações; um maior fortalecimento na conduta para enfrentar problemas, mudança no estilo de vida, maior qualidade de saúde, maior qualidade de vida. (E9)

Nos excertos acima apresentados é possível identificar duas posturas no que se refere ao "empoderamento das mulheres".

Uma das posturas se aproxima mais do que seria o conceito de empoderamento encontrado na literatura científica e cunhado pelos movimentos feministas. Trata-se de um 
movimento de fortalecimento através do encontro entre mulheres e que as prepara para o enfrentamento da própria vida, a resolução de conflitos e as mudanças nos projetos de vida. Podemos observar que as entrevistadas E1, E4 e E7 apresentam este discurso.

Já a profissional E2 parece não conhecer o conceito de "empoderamento" e até mesmo reforça o estereótipo de que "mulher é vaidosa" e que ser feminina é estar preocupada com a aparência, e que o poder feminino vem da beleza (objetificação).

A entrevistada N4 problematiza a importância de não perder de vista a emancipação, ou seja, "a consciência que o outro pode ter de si mesmo", ao se utilizar conceitos em forma de jargões.

Acabam criando também uma outra ditadura, né, do empoderamento, entendeu? E ai, uma reprodução, uma vomitação de coisas que não são necessariamente elaboradas, não são necessariamente emancipatórias, então é uma militância de discurso comprado também, né. Porque gruda no sentimento mas é pouco potente pra construir as suas próprias estratégias e elaborações. (N4)

3.3.1.4 Grupo de Mulheres como estratégia de cuidado às necessidades ampliadas de saúde

As trabalhadoras consideram que o Grupo de Mulheres seja um espaço de cuidado muito importante na UBS A".

O Grupo de Mulheres é um grupo muito importante na unidade, porque a gente tem um número grande de mulheres, com $\mathrm{N}$ necessidades. (E7)

Eu acho que são grupos que estão surtindo efeito. (E8)

Não tenho muito conhecimento desse grupo como funciona, eu sei que funciona, elas falam. (E9)

Apesar de nunca terem participado do grupo "pra conhecer mais a fundo" (E5), em linhas gerais, todas as trabalhadoras apresentam uma descrição similar sobre o seu funcionamento e população-alvo, reforçando a fala e a escuta como potenciais deste espaço grupal.

É um espaço onde cada uma tem o direito de falar, de expor as suas necessidades e de contribuir também de alguma forma. É onde a mulher vai adquirir vários conhecimentos, é, trocas de experiências, mulheres que eu já atendi e que participaram do grupo, elas saem mais fortalecidas [...] 
mulheres jovens adultas, e que têm muita demanda pra psicólogo, ou mulheres em situação de violência, ou qualquer tipo de sofrimento. (E7)

É um espaço de encontro, um espaço que você possa falar, que você possa encontrar pessoas que passam por situações semelhantes a suas, eu acho que é muito importante assim, ainda mais para mulheres que vivem, mesmo que, sem violência, né. Passam por situações opressoras, de que o cuidado da família é dela, de que o cuidado da casa, né, é obrigação, de até uma opressão psicológica assim. Então acho que ter espaço pra mulher pensar, pra ouvir outras pessoas, pra problematizar essas questões, acho que é importante $[\ldots]$ mulheres que estão um pouco, com dificuldades relacionais [...] dificuldade de lidar com as questões da vida, acho que as mulheres que sofrem violência, acho que todas. (E4)

É um grupo de cuidado pra mulher, que elas vão ter um espaço aberto pra se quiserem falar. Quem não quiser falar, não vai falar, mas é um espaço de cuidado pras mulheres e de troca de experiências. Eu penso que não necessariamente o profissional que está ali vai direcionar as conversas, às vezes, uma delas mesmo vai aconselhar a outra. [...] Eu nunca entrei, mas eu acho que é grupo que tem que existir [...] essas que dentro de casa, as que sofrem violência, essas que dentro de casa se sentem sobrecarregadas, ah, até a gente mesmo, profissionais. (E3)

Eu acho que é um sofrimento que une as mulheres ali naquele grupo [...] onde eu posso ser acolhida sem que ninguém me julgue? [...] o grupo não condena ninguém, não condena, é um espaço de escuta, de reflexão. E eu acho que essa tomada de consciência ela é natural [...] eu não sei, se é uma característica do grupo ou é uma característica minha de mandar pessoas com essas características, mas assim, normalmente eu mando essas mulheres que vêm com essas questões mais de depressão e com a questão da autoestima. (E1)

Como principais dificuldades, as trabalhadoras apontam a falta de divulgação e esclarecimentos sobre o funcionamento do Grupo, até mesmo dificuldade de encontro com as coordenadoras para discutir os casos e perguntar sobre as mulheres que frequentam. Referem também ser difícil conseguir "linkar [o grupo] com aquele problema naquela hora [...] atendendo as pessoas e tem que dar conta" (E4).

Eu acho que as pessoas não sabem exatamente quais são os pacientes que devem ir pra esse grupo, e da mesma forma que os outros [grupos] [...] não vou te dizer que eu mande pacientes sem antes discutir junto com a equipe NASF. Principalmente por intermédio da [fisioterapeuta do NASF], mas é muito relacionado mais ao grupo de Práticas [Integrativas], porque eu acabo conversando mais com a fisio [coordenadora do grupo de Práticas Integrativas], então tem um monte de paciente que vai e a gente conversa: e a dona Laura foi no grupo? Foi. (E8)

Eu não sei o quanto é claro pra todos os profissionais o que é feito no grupo, qual o objetivo que é trabalhado. (E4) 
Divulgam pouco, eu acho [...] Quando a gente divulga: quando aparece o caso que a mulher relata sofrimento, aí a gente lembra de falar do grupo, pras que quando não aparece tão claro assim, não é divulgado. (E3)

Quando a gente fala na palavra 'grupo', ela [mulher] entende que isso não é um cuidado. (E6)

Apesar das dificuldades apresentadas, a opinião das trabalhadoras é compatível com a descrição feita pelas próprias coordenadoras do espaço, e principalmente, de que se trata de um espaço exitoso de cuidado.

Elas [usuárias] mesmas escolheram [o nome] 'Grupo de Mulheres', mas era um grupo de saúde mental voltado pra mulheres, porque a gente tinha muitos atendimentos, muita demanda de atendimento [...] e trabalhar muito a questão dos direitos das mulheres, do empoderamento [...] Surgiu muito forte com os relatos das mulheres, até com a forma como a gente foi conduzindo de todo mundo ser corresponsável pelas atividades do grupo [...] não que foi a proposta inicial [...] nós, que fomos coordenando, junto com as mulheres, fomos levando, fomos direcionando pra esse lado. (N2)

Grupo de cuidado que tem aqui na UBS pra essas mulheres [...] de saúde emocional [...] de empoderamento [...] tem se falado mais sobre o feminismo $[\ldots]$ mulheres com questões e sofrimentos emocionais, violência, violência doméstica. Já tiveram questões graves de abuso [sexual], ansiedade, com depressão, pacientes que têm problemas com os filhos, é, deficiência intelectual, algum tipo de dificuldade na vida, pra circular também [...] tentar evitar que isso se agrave, a maior parte já está bem adoecida. (N1)

O mesmo pode ser observado nas falas das mulheres participantes.

Eu passava numa médica e daí ela falou assim que eu precisava porque que eu falei pra ela que eu sonhava com umas coisas meio estranhas assim, então, mandou eu fazer alguma coisa pra ocupar a mente [...] você pensa numa coisinha: ai, sua irmã é chata, e tem gente pior e daí se torna nada [...] Que eu faço alguma coisa e esqueço quando a minha irmã briga comigo né, daí eu esqueço [...] [o Grupo de Mulheres] É bom pra esquecer os problemas e pra sair de casa um pouco. (M1)

O Grupo de Mulheres ele é uma boa experiência, assim, é pra você conhecer outras pessoas, pra você contar a sua história, acho que pra melhorar não só o convívio social, pra se ajudar, pra você ver: nossa, o que está acontecendo lá? $\mathrm{O}$ que eu posso melhorar na minha casa? $\mathrm{O}$ que eu posso fazer pela pessoa, pra ela melhorar na casa dela? O cuidado que as pessoas deixam de ter por causa de outras, porque tem muita mulher que: ai, eu não vou num cabeleireiro, arrumar o meu cabelo, porque eu preciso fazer a janta pro meu marido [...] ali é um espaço pra cada um expor a sua opinião [...] é um espaço que a gente tem pra dividir as experiências, e absorver aquilo que acha necessário [...] Eu acho que o grupo ele ajuda, assim, eu converso mais, em casa eu fico mais calada, eu fico sozinha [...] é um jeito de sair um 
pouco da caixa que eu entrei né, porque a gente começa a pegar todos os problemas e fico remoendo, remoendo. Eu paro de viver, eu paro de sair de casa, eu paro de fazer as coisas, eu paro de conversar com as pessoas, e eu entro numa caixa, e eu fico sozinha lá no escuro, o tempo todo. (M2)

Eu tenho a consciência que eu preciso fazer a terapia a vida inteira, eu quero fazer mesmo, só que às vezes enche o saco, é cansativo, mas, eu sei que eu estou me tratando e que eu tenho que levar o tratamento muito a sério, não é isso? Sempre eu tive essa consciência [...] Do grupo, eu gosto, as pessoas são legais, parecem ser bem sinceras, e tudo, e, respeito, também não comento nada, o que é do grupo, fica no grupo mesmo [...] o grupo de mulheres me ajuda muito, é um apoio muito bom, eu procuro vir direitinho. (M3)

O Grupo de Mulheres é onde reúne várias mulheres, a gente faz roda de música, faz... desabafa, fala um pouco dos nossos problemas. Faz danças de roda, Artes. Pra incentivar uma amiga que faz esse tipo de trabalho, e ela não divulgava o trabalho, e aí a gente achou melhor divulgar entre nós. Experiência de uma, passar a experiência de uma pra outra [...] [mulheres que] Passam por necessidades de se autovalorizar. Por algum motivo de crise, nervosa, emocional. Aí é onde elas procuram ajuda [...] Faz a gente refletir melhor sobre a vida da gente, né [...] o grupo também ajuda porque você pega experiências de outras mulheres pra sua vida. (M4)

Nos excertos acima, as mulheres enfatizam a possibilidade de trocar com outras mulheres, com encontro e confronto de experiências, bem como conexão e implicação com o sofrimento da outra. Em contrapartida, algumas trabalhadoras reforçam o fato de se tratar de um espaço livre de compromissos, "que não tem regras" (E7), o que não condiz com as descrições trazidas pelas participantes de grande implicação umas com as outras; o respeito e o sigilo são regras de grande importância deste espaço, como trazido anteriormente por M2 e M3, respectivamente.

Um espaço muito livre onde as pessoas vão se colocando à medida que elas se sentirem confortáveis pra se colocar, tanto no fazer quanto no falar. E eu vou sentindo muito que vocês fazem um espaço assim, que vocês recebem as pessoas e que vocês vão decidindo o que vocês vão fazer. (N3)

[Um] espaço em que as mulheres possam, é, se sentir mulher, mulher mesmo, livre de qualquer coisa, um espaço assim, pra elas se sentirem acolhidas, pra fortalecer, pra trocar. (N2)

Nós temos um grupo, que é um grupo muito interessante, que não tem regras. (E7)

Como recurso de análise de eficácia do Grupo, tem-se as avaliações das profisssionais e das usuárias que referem observarem "melhoras", e algumas entrevistadas trazem de maneira mais clara o que viria a ser esta "melhora". 
Quando eu me sinto bem, eu me afasto, aí quando eu me abalo um pouco, eu volto a procurar de novo. Porque até os profissionais percebem que a gente está bem, quando a gente não precisa deles, tem outras pessoas que necessitam, então, abre espaço pra outras pessoas que necessitam. Porque se a gente está bem, não precisa procurar médico, né, caminha sozinha. (M4)

Tem momentos que né, fica esvaziado, que elas dão uma pausa, mas que depois elas retomam, mas acho que faz parte, eu acho que isso faz parte da vida mesmo, dos momentos que a gente passa, que a gente enfrenta [...] E a gente tem o retorno também, que elas trazem que gostam do grupo [...] eu observo que elas se fortaleceram muito ao longo desses anos no grupo. (N1)

A gente foi vendo pessoas chegarem com muito sofrimento, escutar uma palavra, se mobilizando e foi fazendo sentido pra essa pessoa E que ela foi melhorando, foi estabilizando, né, e esse movimento das saídas, porque a gente ficava preocupada se elas estavam bem, mas muitas estavam muito bem, por isso estavam indo embora. (N2)

Eu sinto que [o Grupo de Mulheres] tem um lugar importante na UBS, porque as pessoas falam do grupo. Então eu acho que, eu não entendo que é um grupo do NASF, apesar de ser só coordenado pelo NASF, é um grupo da UBS, que eu acho que essa é uma outra diferença [...] é um grupo forte, que a unidade acredita, valida. (N3)

\subsubsection{O processo grupal}

\subsubsection{Mulheres "extraordinárias"}

Nota-se no conjunto das entrevistas das mulheres participantes do Grupo, que sua história individual é fortemente determinada pela história do bairro, pela ausência de equipamentos do Estado e por sua participação social.

Conforme apresentado pelas entrevistadas (tanto profissionais quanto participantes do Grupo) o Grupo de Mulheres é reconhecidamente potente para o cuidado das necessidades ampliadas de saúde das mulheres deste território.

Para aprofundar esta afirmação, a seguir, será feita uma análise sobre a contribuição de cada umas das quatro mulheres entrevistadas para o processo grupal, bem como da contribuição do Grupo para o processo de recuperação de saúde de cada uma delas. Esta análise foi baseada nas observações anotadas em Diário de Campo e nos relatos das próprias mulheres. 
Nesta seção foram atribuídos nomes fictícios a estas quatro mulheres, inspirados em mulheres "extraordinárias" que revolucionaram o nosso país (Souza; Carraro, 2017 e Favilli; Cavallo, 2017). Em um dos encontros do Grupo de Mulheres, cada participante foi convidada a escolher a história de uma destas mulheres extraordinárias e a pensar sobre o "extraordinário" de suas próprias histórias de vida. Os nomes atribuídos são em referência às mulheres extraordinárias que as participantes do grupo escolheram conhecer naquele encontro.

a) Anita (M1) - pilar histórico do Grupo de Mulheres

Anita tem 36 anos, é negra, e estudou até a sexta série do Ensino Fundamental. É reconhecida como deficiente intelectual, lugar construído pela família e pela escola. Repetiu de ano diversas vezes por "não saber das coisas" (M1). Sua demanda para o serviço de saúde foi aprender a andar de ônibus e com o tempo pudemos entender melhor as suas necessidades.

Ela foi uma das mulheres fundadoras do Grupo, junto com as profissionais, e tem se mantido participando desde então, com pequenos períodos de ausência.

Anita apresenta crítica em relação à determinação social e racial/étnica de sua família, reconhece certa reprodução de padrões entre as suas 3 irmãs, e tem exercitado a sua diferença como uma forma de quebrar este ciclo. Desta maneira, com o apoio técnico do Programa Acompanhante Comunitário de Saúde da Pessoa com Deficiência (APD), tem se utilizado de seu diagnóstico para transitar por espaços culturais, fazer cursos de seu interesse e futuramente obter um emprego/uma profíssão.

Anita representa portanto um pilar histórico deste Grupo e sempre se lembra de algumas das antigas participantes. Assim como o Grupo, Anita tem se mostrado mais consistente, mais confiante em si mesma, e mais madura, assumindo seus próprios desejos, autonomia e independência. Ela sempre percebe as ausências e a maneira como as outras mulheres estão presentes e coloca estas questões na roda, trazendo assim que o aparelho grupal se constitui processualmente e todas as mulheres têm a sua parcela de contribuição na construção deste espaço.

b) Dandara (M2) - ponto de ancoragem do empoderamento 
Dandara tem 26 anos, é branca, e chegou a cursar o primeiro ano de um curso do Ensino Superior. Engravidou muito jovem (20 anos) porque o namorado escolheu tirar o preservativo, durante a relação sexual, sem o seu consentimento.

Hoje, ela compreende que muito de seu sofrimento emocional, nomeado "depressão", está relacionado a esta situação.

Ela viveu situação de violência de gênero, quando sua escolha não foi respeitada por seu companheiro, e apresenta muitas críticas em relação à instituição casamento. Em seu cotidiano, na relação com seus pais, sua irmã e sua filha, Dandara vivencia as consequências da "escolha do outro" e presencia a interferência das questões de gênero, principalmente, na relação com seu pai.

Outra situação de violência vivida por Dandara aconteceu durante a sua gravidez, em que eram dificultadas as suas idas ao banheiro, durante o expediente de trabalho. Nesta situação, Dandara acionou a justiça e ganhou direito à indenização. No entanto, desde o nascimento de sua filha sempre teve dificuldades para receber a pensão alimentícia do pai da criança, tentando fazer negociações baseadas no diálogo e na confiança.

No Grupo, Dandara tem sido um importante ponto de ancoragem do empoderamento. Como é a mais jovem se coloca como porta-voz de uma geração que problematiza as relações conjugais e traz um discurso de embate quando outras mulheres apresentam suas queixas sobre tais relacionamentos com seus maridos. Em seu discurso não há culpabilização das mulheres, mas dos homens, e sem se reconhecer feminista, se coloca intensamente relacionada ao movimento da segunda onda. Dandara tem se reconectado com seu hobby desenhar e depois de anos com dificuldades para sair de casa, tem procurado emprego.

c) Nise (M3) - questionamento da loucura

Nise tem 44 anos, é parda, e chegou a cursar 1 ano no Ensino Superior. Nasceu em uma família grande, de "pai branco e rico e mãe negra e pobre”. Por esta relação inter-racial, contra a vontade das famílias, ela e os 10 irmãos foram renegados pela parte rica da família mesmo após a morte de ambos pais quando ainda era uma criança, chegando a passar fome. A única maneira que seus parentes a aceitaram e a algumas de suas irmãs foi sob a condição de serem empregadas domésticas e com 10 anos trabalhou na primeira casa. Como salário recebia comida, teto, um vestido novo ou reformado em datas festivas e materiais escolares. 
Desta forma, manteve-se estudando. Nise passou por diversas situações de violência sexual de patrões, irmãos e conhecidos; chegou a ser estuprada duas vezes.

Ela é a única mulher do Grupo, paciente da parte Tradicional da UBS, e foi através de suas referências no CAPS adulto que passou a participar do espaço. No CAPS ela nunca aceitou participar de atividades grupais e sempre interrompia qualquer tipo de atendimento para fumar um cigarro. Sua condição para participar foi poder sair para fumar e ir embora a hora que quisesse, dizendo não ser possível participar de um grupo de 2 horas de duração. No primeiro dia ela só manifesta desejo de fumar depois de uma hora de participação no Grupo, e se surpreende consigo mesma. Além disso, neste dia também participou do encontro integralmente, por 2 horas.

No Grupo, Nise personifica o questionamento da loucura, e sempre (se) pergunta: "eu sou louca?". Mesmo apresentando confusão mental, sonolência e, por vezes, certa impregnação por conta das medicações psiquiátricas, esta parece ser uma pergunta que faz a si mesma, provocada pelos diversos diagnósticos que recebeu e pela percepção de si. As mulheres não se referem a ela desta forma e não a tratam como alguém "sem a razão", respeitando as suas saídas, esperando o seu retorno para a continuação de determinada atividade, mesmo quando ela se recusa a participar mais ativamente.

Quando Nise nos coloca este questionamento de maneira humilde e generosa, outras mulheres referem elas mesmas já terem sido chamadas de loucas ou terem se considerado desta maneira, não acreditando em seus sentimentos e sofrimentos. A partir da experiência de Nise, sempre está em pauta o questionamento dos diagnósticos, das medicações e como temos o cotidiano medicalizado. Afinal, todas as mulheres apresentam situações de muitas dificuldades, violência e privação financeira, que vivenciam com intenso sofrimento. Mesmo em situações de crise, Nise procura a UBS e o Grupo como estratégias de cuidado.

\section{d) Cora (M4) - sustentação da identidade grupal}

Cora tem 34 anos, é negra, e estudou até a sétima série do Ensino Fundamental. Sua mãe é branca e o seu pai era negro. Dos 13 irmãos, ela refere ser a pessoa com a pele mais escura e que por esta razão foi doada pela mãe. Uma irmã mais velha a recupera e a cria; nesse período, um dos irmãos tenta abusar sexualmente de Cora, que foge com a ajuda dessa irmã, e vai morar sozinha numa cabana abandonada. Ela tinha 8 anos. Apanhava café para se 
sustentar e se manter na escola. Aos 14 anos, engravida e logo depois, no final de sua gravidez solitária, conhece o atual companheiro, 30 anos mais velho que ela. Ele a assume como esposa, cria o filho dela como seu e juntos têm mais 3 filhos. Hoje este homem é seu excompanheiro, mas sempre a humilhou, a proibia de ter amigos e de sair para se divertir, desejando dela uma postura recatada e submissa.

Os filhos mais velhos, já maiores de idade, reproduzem as mesmas violências contra Cora que sofre com depressão e ideação suicida, que eles dizem ser "frescura" dela.

Ao se mudar para o território da UBS A”, começa a fazer acompanhamentos de saúde e é diagnosticada como hipertensa e diabética.

Cora participa desde o início do Grupo em 2014, com idas e vindas e entende que suas saídas coincidem com os momentos em que estava se sentindo bem apesar de suas questões, e que tinha conseguido voltar a trabalhar. Cora parece reconhecer no Grupo de Mulheres um espaço de tratamento e por isso, espera deixar de participar quando estiver bem.

É interessante ressaltar que muitas mulheres têm estendido as suas relações para além deste espaço de encontro, e em grupos menores ou pares, têm se constituído em rede de apoio umas às outras. A amizade entre Cora e Dandara é um exemplo deste movimento.

Cora tem facilidade para expressar os seus pensamentos e sempre participa ativamente dos debates do Grupo. Tem sido uma figura importante nos processos de tomada de decisão e de responsabilização, garantindo assim a retomada de pilares centrais da identidade deste grupo.

Outra questão de extrema importância sobre o funcionamento deste espaço grupal é o processo de ensinar-aprender (que será descrito a seguir na seção "3.3.2.2 Sistematização do processo grupal"). Cora foi a primeira participante a ministrar uma oficina para as outras mulheres do Grupo - como crocheteira profissional ensinou, pacientemente, esta atividade e valorizava muito os aprendizados de cada uma das participantes. Propusemos esta oficina com o intuito de incentivá-la a retomar esta atividade muito significativa em seu cotidiano, atividade que até lhe havia gerado certa independência financeira, mas que foi negada durante o seu processo de adoecimento. Após esta primeira oficina, ensinar-aprender tornou-se um importante foco de trabalho neste Grupo e Cora retomou o seu contato com o crochê. Além disso, decidiu se separar do companheiro e tem conseguido sair sozinha e procurar emprego. 


\subsubsection{História do Grupo de Mulheres}

Considerando a demanda de cuidar de mulheres e as manifestações de suas diversas situações de sofrimento (adoecimentos), comuns e severos, a pesquisadora, sendo terapeuta ocupacional desta equipe de NASF A, junto a psicóloga e uma das fisioterapeutas, propuseram em maio/2014 um "Grupo de Saúde Mental” somente para mulheres.

As mulheres deste território apresentaram diversas situações de sofrimento relacionadas a questões de gênero, violência contra a mulher, vulnerabilidade social, a vida na periferia metropolitana entre outras. Assim, ao ser considerada a potência da estratégia grupal, as profissionais propuseram este espaço que inicialmente seria: fechado (composto pelas mulheres já atendidas pelas profissionais), com frequência quinzenal (às sextas-feiras, com duas horas de duração). As novas usuárias seriam convidadas após discussão de PTS na equipe ampliada - NASF e ESF, e só seriam incluídas no Grupo em dias determinados previamente.

No ano de 2014, uma ACS e uma estagiária de psicologia passaram a compor a coordenação com o trio coordenador, e o Grupo foi realizado em uma das igrejas do território, tendo sido divulgado para a maioria dos profissionais da UBS, tanto da ESF quanto da UBS Tradicional. As outras profissionais do NASF se tornaram as principais aliadas na identificação dos sujeitos que se beneficiariam deste Grupo. Após o início dos encontros, a proposta foi remodelada a partir do pequeno número de participantes: o grupo tornou-se aberto, com possibilidade de entrada de novas participantes em qualquer encontro. Algumas mulheres manifestaram incômodo com "Grupo de Saúde Mental”, por não se identificarem como "loucas", ao que este nome remetia; assim, o grupo foi batizado como "Grupo de Mulheres".

No fim do processo, pudemos contar com a participação fixa de cinco mulheres, e outras mulheres participaram de forma flutuante e em sua maioria, em um único encontro. Desta maneira este grupo, desde sua constituição, precisou cuidar da recepção e desligamento tanto de participantes quanto de coordenadoras (saída da ACS, que se dizia "misturada" àquelas mulheres; saída da psicóloga por conta da gestação e consequente Licença Maternidade; saída da estagiária de psicologia em razão do fim do estágio). Em 
dezembro/2014, houve um recesso, em razão de feriados de final de ano (Natal e Ano Novo) porém, combinamos que a retomada dos encontros seria em janeiro/2015.

No ano de 2015, devido a uma reforma do prédio, o Grupo não pode ser realizado na igreja, assim, foi transferido para uma sala no Centro de Referência Assistência Social (CRAS). Além da terapeuta ocupacional e da fisioterapeuta, havia uma psicóloga com vínculo empregatício temporário para cobrir a Licença Maternidade da profissional efetiva e outra estagiária de psicologia passou a acompanhar este trabalho. Posteriormente, a psicóloga efetiva retornou da Licença Maternidade, retomando sua participação no Grupo e consequentemente, houve a saída da profissional temporária. O número de participantes foi aumentando significativamente, principalmente no segundo semestre, e atribui-se a isso algumas situações: devido ao CRAS ser mais próximo da UBS A”. O grupo completou ter completado um ano de existência, sendo realizado no mesmo período e dia da semana desde sua fundação, o que facilitou sua divulgação; como estratégia para receber mulheres acompanhadas por outras profissionais. As coordenadoras do grupo reservaram horário de acolhimento em suas agendas; realizaram divulgação da proposta em reuniões internas e fóruns externos de trabalhadores da saúde. O Grupo não pôde mais ser realizado no CRAS por falta de espaço, uma vez que o local abrigaria um novo projeto de território direcionado à juventude. Assim, em novembro/2015, os encontros começaram a ser realizados na sala do NASF na UBS, recém-inaugurada.

Em 2016, a partir das reflexões suscitadas apenas pela ideia de realização deste projeto de pesquisa, a coordenação do Grupo decidiu fazer uma lista de presença, anotando o nome de todas as mulheres que passaram pelo grupo, mesmo que apenas uma vez, bem como lançar a frequência de participação, com o intuito de que servisse para a busca ativa das participantes que viessem a faltar. Depois dos recessos de final e início de ano, as atividades foram retomadas em janeiro de 2016. No começo das atividades, cada participante recebeu um calendário com as datas de todos os encontros, o que parece ter facilitado que as participantes se organizassem para retornar, mesmo havendo faltado, assim, cada participante teria autonomia para organizar suas ausências e presenças nos encontros. Outra decisão do trio coordenador foi não interromper as atividades do grupo por mais de um mês, algo que as próprias participantes assinalaram como positivo.

Neste ano, não houve nenhum outro profissional ou estagiário auxiliando na coordenação. E mesmo sendo três as coordenadoras, devido a demandas do trabalho, 
capacitações e questões pessoais, bem como férias das profissionais, a maior parte dos encontros foi conduzida em dupla. Houve, em alguns encontros de maio e junho/2016, até mesmo a necessidade de participação de outras profissionais da equipe NASF - a fonoaudióloga, a assistente social e a psiquiatra.

Outro apontamento sobre os encontros do Grupo em 2016, foram as atividades em que as próprias mulheres eram as coordenadoras e uma destas atividades parece ter sido tão importante que desejaram continuar no próximo encontro: uma das mulheres ensinou a fazer crochê. Duas delas disseram que este encontro despertou-lhes o desejo de retomarem esta atividade em seus cotidianos, algo que tinham abandonando devido aos processos de adoecimento.

No ano de 2017, foi realizado o Trabalho de Campo desta pesquisa e consequente registro em Diário de Campo. Destacamos algumas situações do processo grupal ocorridas neste ano: retorno das atividades no CRAS a partir de junho/2017 e a mudança do horário do Grupo, de $9 \mathrm{~h}$ às $11 \mathrm{~h}$, para $10 \mathrm{~h}$ às $12 \mathrm{~h}$, devido à necessidade profissional de realizar outro grupo no mesmo dia da semana (sexta de manhã). O espaço do CRAS é mais versátil e mais tranquilo que a UBS, e não houve manifestação das mulheres sobre dificuldades em relação à mudança do horário. Comparado com 2016, o Grupo recebeu menos participantes, porém, houve mulheres que participaram de maneira mais fixa durante todo o ano e também o retorno de participantes antigas, sendo que uma delas trouxe os filhos por não ter com quem deixálos. Enfim, mulheres com seus diversos perfis de participação (fixo, flutuante, pontual).

\subsubsection{Sistematização do processo grupal}

Uma das formas de organizar a periodicidade de um Grupo de Mulheres é através de encontros quinzenais, com 2 horas de duração. Os encontros quinzenais são mais facilmente inseridos nas atividades cotidianas de trabalho remunerado, trabalho doméstico e cuidados dos filhos. Desta forma, pode-se optar por um encontro mais longo, com 2 horas, para possibilitar o cuidado das questões que se apresentam e ainda das chegadas constantes de novas integrantes. 
O perfil aberto do grupo provou ser mais adequado para as necessidades das mulheres, que podem sair e retornar quando desejam e podem. Este arranjo possibilita diversas composições de participação no espaço: fixo (por um determinado tempo), mais flutuante ou até mesmo pontual (uma vez).

Destaca-se a importância de iniciar o encontro com a "Apresentação" dos sujeitos que compõem a roda, da proposta do Grupo e sua condição de grupo aberto, convidando as participantes antigas a se manifestarem, e também com a recepção das novas integrantes. É necessário pactuar e reforçar constantemente o contrato de sigilo sobre o que é tratado entre as participantes, bem como o respeito mútuo, pois "saber quem somos e a que viemos é o primeiro passo para um encontro honesto e, de fato construtivo" (Godoy et al., 2014, p.17). Outra pactuação necessária é o tempo limite de espera para a chegada das participantes com as já presentes, inclusive para garantir que o encontro seja com mais de uma pessoa, e, caso apenas uma pessoa compareça, deve-se consultá-la sobre a condição de manutenção ou não do encontro e de que maneira ele poderia acontecer.

Antes de iniciar esta primeira atividade de "Apresentação", é necessário dispor o espaço em roda, conforme as possibilidades de dimensões do local e disponibilidade de assentos, contando com a ajuda das pessoas já presentes. No final do encontro, deve-se organizar o espaço conforme encontrado. A roda é essencial para enxergar a todas e o direcionamento ao centro, que está igualmente distante das pessoas, faz lembrar da partilha do objetivo e a mesma importância entre os pares (Godoy et al., 2014).

Algumas estratégias podem garantir certa organização e registro histórico do Grupo: lista de presença que possibilita a busca ativa de participantes que vieram a faltar e avaliação do impacto da proposta; calendário com as datas dos encontros do ano para facilitar a programação quinzenal e para que cada participante tenha autonomia em gerenciar suas faltas e retornos; cronograma coletivamente elaborado com propostas de atividades que só é possível de ser seguido quando há um corpo de participantes com certa frequência e ainda, se garantido espaço de recepção das novas integrantes e flexibilidade para atividades mais coerentes com o momento.

Quando há somente participantes novas, o momento de "Apresentação" deve ser o foco do encontro, em que será necessário ser mais propositivo e improvisar atividades, respeitando este momento mais "reservado" de quem chega pela primeira vez. 
É importante ofertar um horário de acolhimento individual para as novas mulheres com pessoas da coordenação, preferencialmente antes de seu ingresso no Grupo, para que as participantes se sintam mais seguras em chegar ao espaço e ainda, para que seja garantida a apresentação da proposta e esclarecimento sobre o funcionamento do Grupo.

Após esta primeira atividade de "Apresentação" (este espaço, estas pessoas), é o momento de acontecerem as outras "Atividades" do encontro, que podem ser escolhidas de duas maneiras: propostas pela coordenação e direcionadas ao cuidado de determinadas situações; propostas pelas próprias participantes, de acordo com repertórios que possuam e experiências prévias neste ou em outros grupos. Qualquer que seja a proposta ou a maneira de propô-la, que se dê em ato ou previamente, é sempre necessário garantir a negociação coletiva.

O papel da coordenação vai desde a garantia de quesitos materiais para a realização do grupo, como espaço, cadeiras, convites e divulgação, até a tarefa mais complexa de mediação. Mediar um grupo não se trata apenas de fomentar o encontro dos sujeitos, mas, cuidar deste encontro e de cada mulher individualmente; implica fazer leituras constantes das manifestações das participantes; proposições de atividades que acolham suas necessidades; observação atenta dos gestos, expressão corporal e desejos; enaltecimento das questões apresentadas individualmente para uma elaboração coletiva; cuidado para que as colocações de todas as participantes sejam acolhidas e ainda, respeitadas, sejam elas mais calorosas ou “apenas" com a presença. Além da organização de espaço e da mediação, a coordenação deve realizar avaliações constantes do processo grupal, das relações e das necessidades das mulheres.

Ressalta-se a importância de três profissionais na coordenação, uma vez que o cotidiano do trabalho na Atenção Básica é muito dinâmico e mutante, desta forma, facilita-se a garantia de participação de duas coordenadoras. Considera-se essencial que a coordenação em ato seja feita minimamente em dupla, pois mesmo com certo planejamento, acontecem imprevistos, o que exige capacidade de improviso e de criação com os recursos disponíveis, uma situação de grande complexidade (Godoy et al., 2014).

São importantes pilares de um grupo, a negociação permanente e a horizontalidade. Assim, as participantes podem se apresentar como co-terapeutas e corresponsáveis pelo Grupo, em que a resposta coletiva é forma privilegiada de direcionamento das questões e propostas (Godoy et al., 2014). As coordenadoras devem estar sempre disponíveis para os 
pedidos de "conversa individual" que venham a aparecer mesmo que seja agendada posteriormente. Entendemos a necessidade de respeitar estes pedidos, desde que sejam sempre reforçadas as potências do espaço grupal.

Um grupo funciona de acordo com o repertório técnico e pessoal de quem o coordena, assim como a história e as condições de vida das próprias participantes influi diretamente no perfil destes encontros; a condução deste Grupo de Mulheres foi realizada por uma terapeuta ocupacional, uma psicóloga e uma fisioterapeuta, desta forma, temos a configuração que é apresentada neste trabalho. As coordenadoras precisam estar sempre atentas e disponíveis para buscar alinhamentos teóricos e técnicos, de acordo com as necessidades que se apresentam no processo grupal.

De acordo com a experiência do Grupo de Mulheres e considerando que este material foi produzido por uma terapeuta ocupacional, a seguir será apresentada uma análise mais aprofundada sobre o elemento "Atividades" em que:

as atividades indicam campos da produção cultural, compreendendo um conjunto de hábitos, técnicas, instrumentos, materiais, formas socialmente estabelecidas de fazer e conhecimentos historicamente constituídos. É nesse sentido que podemos falar da atividade de pintura, de dança, de marcenaria, de ensino, de pesquisa, de jogos e brincadeiras etc. Já a ação designa um ato único, irreversível e singular que expressa o agente (Arendt ${ }^{21}, 2000$, apud Lima et al., 2013, p.250-1).

As Atividades do Grupo de Mulheres podem ser apresentadas da seguinte forma:

- Atividades de ensinar-aprender, em que as habilidades de cada uma são valorizadas e as próprias participantes experimentam serem coordenadoras neste processo de ensinar o que sabem (exemplos: desenho, pintura, crochê, biscuit);

- Atividades de discussões temáticas, que precisam ser escolhidas previamente (exemplos: saúde reprodutiva e sexualidade; sofrimentos psíquicos e psicotrópicos; Lei Maria da Penha; violência de gênero; relacionamentos abusivos; direitos humanos)

- Atividades de rodas de conversa abertas, baseadas nas manifestações que emergem em um determinado encontro de acordo com as questões individuais apresentadas, sua problematização e reflexão coletiva;

- Atividades dirigidas pela coordenação, que implicam um repertório de vivências (experiências estéticas, por exemplo), ou um saber técnico como algumas modalidades de

21 Arendt H. A condição humana. Rio de Janeiro: Forense Universitária; 2000. 352 p. 
Práticas Integrativas e Corporais em Saúde - PICS (exemplos: massagem, meditação, exercícios para o assoalho pélvico, danças circulares, fitoterapia, confecção de mandalas).

Pode haver também a proposição de Atividades já realizadas em outro momento, porém, cada encontro é um encontro diferente do outro, se considerarmos que existe uma transformação das pessoas pela atividade. É importante nos percebermos diferentes na relação com determinado fazer, a partir de uma investigação e transformação da relação com este fazer, pois nos processos de sofrimento psíquico e adoecimentos é muito comum o rompimento do cotidiano ocupacional, desde as atividades necessárias e obrigatórias (trabalho, escola, cuidados da casa e da família) e principalmente, das atividades criativas (cursos, artes, atividades corporais, sexo) e de autocuidado (higiene, estética, alimentação).

Outro destaque está em incentivar que as Atividades experimentadas no Grupo sejam utilizadas pelas mulheres quando estão sozinhas, angustiadas, tristes, com dificuldades, se configurando como instrumento de extensão da continência do espaço grupal e também como mecanismo de cuidado de si mesmas. Também é importante investigar o perfil ocupacional destas mulheres, para além das atividades laborais e de cuidados com a casa e a família, e instigar a realização de atividades de interesse outrora realizadas.

Em seguida à realização das Atividades, é importante conduzir um momento de compartilhamento das experiências.

Ao propor atividades devemos considerar que elas têm funções e efeitos que são se resumem a serem disparadoras de discussões e elaborações. As pessoas se transformam também no feitio das atividades e nem sempre serão transformações tangíveis à expressão da fala. O feitio de atividades possibilita ressignificação de experiências, resgate de memórias afetivas e também da potência criativa, bem como experimentação de pequenos prazeres e reconhecimento de habilidades. Por isso a importância de proposições e análise de Atividades a partir dos encontros com os sujeitos, em que para além da "atividade em si", devemos estar atentas "ao movimento criativo onde quer que ele apareça" (Lima, 2004, p.47) pois tão importante quanto a realização de uma Atividade, incluída social, cultural e historicamente, é a "forma singular de fazer [...] quando um sujeito se faz presente em ato" (Lima et al., 2013, p.251).

Por fim, ao final de cada encontro, cabe realizar um planejamento do próximo encontro, seja para a sugestão e organização de uma Atividade ou mesmo para decidir se as Atividades ficarão a cargo das coordenadoras planejarem. 
Destaca-se a importância de não realizar prescrição de alta, em que se trabalha no sentido da autonomia das mulheres para irem e retornarem quando desejarem ou necessitarem. Vale acrescentar que é importante uma atenção para as ausências, avaliando quando é expressão de autonomia ou quando é expressão de certa paralisia, e fazer um acompanhamento desta questão.

Algumas estratégias podem ser criadas para facilitar a participação das mulheres e ainda a manutenção do Grupo. Uma delas é a possibilidade de que as mulheres tragam os seus filhos para o espaço. Outra estratégia é o respeito às idas e vindas e tempos de permanência possível no encontro (pressa, atrasos, sair para fumar, ficar só olhando, sair mais cedo). Compreendemos que participar do Grupo não implica apenas se colocar e fazer as Atividades propostas, apesar de ser necessário tentar negociar que a pessoa ao menos tente realizar determinada Atividade. Somente o se dispor a vir já é um processo de grande importância, e com o tempo, as pessoas se sentem mais à vontade para estarem em roda e se colocarem.

É recomendado que anualmente (ou em outra periodicidade desejada), seja realizada uma avaliação do Grupo junto com as participantes, sobre o funcionamento, dificuldades e potencialidades do espaço grupal, bem como sobre a colaboração do Grupo nos processos individuais.

Para além da divulgação interna, algo a ser constantemente reforçado, vale divulgar o Grupo de Mulheres nos fóruns de trabalhadores e em outros serviços de saúde e de outros setores. Assim, possibilita-se que o Grupo se torne um espaço de contra-referência das mulheres que fazem acompanhamento em outros serviços para além da UBS, possibilitando continuidade aos processos terapêuticos que já realizavam.

Por fim, tentar manter os encontros do Grupo de Mulheres no mesmo período e dia da semana, ao menos durante um ano, para facilitar o retorno de mulheres, que foram participantes e a divulgação dessa proposta de cuidado. 


\section{DISCUSSÃO}

Na Saúde Pública as práticas de saúde são organizadas visando-se alcançar o maior número de pessoas. As Políticas Públicas, independente dos conteúdos que defendem, são aplicadas com baixa destinação de recursos.

O retraimento de investimentos públicos no setor Saúde vem afetando profundamente a qualidade da assistência à saúde, o que inclui os princípios da integralidade e da humanização, os quais exigem investimento de recursos para sua concretização [...] no contexto do Estado neoliberal, em que o mercado regula demandas e necessidades da sociedade, as políticas de saúde têm se voltado, particularmente nas últimas décadas, para a redução do gasto público em saúde, paralelamente à crescente privatização deste setor. Concomitantemente, ocorre uma precária e limitada focalização da assistência nos grupos mais 'vulneráveis' (Almeida ${ }^{22}$, 2000, apud Barbosa, 2006, p.327-328).

O modelo biomédico é centrado em práticas intervencionistas e tecnicistas. Esse modelo responsabiliza individualmente o paciente e responde a esta expectativa, sendo “apontado como a única saída possível para a solução da 'crise' do setor Saúde” (Almeida, 2000 apud Barbosa, 2006, p.328). Já está constatado, através de indicadores de saúde feminina, que houve aumento da cobertura assistencial. Porém, estudos mostram o aumento de práticas iatrogênicas, como partos cesáreos e violência obstétrica, e a manutenção da dificuldade de acesso aos serviços básicos de saúde para milhares de brasileiras (Silver² 1999, apud Barbosa, 2006).

A partir das entrevistas, é apontada a limitação do referido modelo perante as necessidades apresentadas pelas mulheres deste território.

Há na UBS A”, a coexistência de dois modelos de assistência em Atenção Básica: UBS Tradicional e ESF. A ESF é reconhecidamente estratégica para possibilitar um processo de superação do paradigma biomédico no qual a UBS Tradicional se baseia. Ou seja, na mesma unidade de saúde operam duas lógicas de cuidado: profissionais que estão sendo formados em ato para a superação do paradigma biomédico e profissionais que continuam a

22 Almeida C. Saúde nas reformas contemporâneas. In: Costa AM, Merchand-Hamann E, Tajer D, organizadores. Saúde, Equidade, e Gênero: um desafio para as políticas públicas. Brasília: Editora da Universidade de Brasília; 2000. 304 p.

23 Silver LD. Direito à saúde ou medicalização da mulher? Implicações para a avaliação dos serviços de saúde para mulheres. In: Giffin K, Costa SH, organizadores. Questões de Saúde Reprodutiva. Rio de Janeiro: Editora Fiocruz; 1999. 468 p. 
operar nesta lógica incutida também por suas graduações. Ambas as lógicas abordam as mesmas pacientes. Na UBS A", comumente ocorrem pedidos das mulheres por certas especialidades, neste caso a Ginecologia, em negativa às consultas com as médicas generalistas. Já é difícil promover a transição do paradigma biomédico para o da clínica ampliada, ainda mais quando a própria gestão propõe coexistência de formas distintas de $\mathrm{AB}$ no mesmo serviço.

Outra característica da influência do modelo biomédico neste serviço, é o arranjo institucional de atendimento à demanda espontânea, denominado contraditoriamente de Acolhimento com Acesso Avançado (Acolhimento). Trata-se de uma breve consulta com profissionais da enfermagem em que o foco é a classificação de riscos de acordo com as queixas e sinais vitais.

O Acolhimento foi alvo das principais queixas das profissionais entrevistadas: esgotamento, frustrações e irritação, são algumas das sensações atribuídas a este dispositivo. Em que, somente a ideia de ter que "cobrir" o Acolhimento já causa angústia nas trabalhadoras. De acordo com a Política Nacional de Humanização (PNH)

acolhimento é uma diretriz [...] que não tem local nem hora certa para acontecer, nem um profissional específico para fazê-lo: faz parte de todos os encontros do serviço de saúde. O acolhimento é uma postura ética que implica na escuta do usuário em suas queixas, no reconhecimento do seu protagonismo no processo de saúde e adoecimento, e na responsabilização pela resolução, com ativação de redes de compartilhamento de saberes. Acolher é um compromisso de resposta às necessidades dos cidadãos que procuram os serviços de saúde [...] A classificação de risco é um dispositivo da PNH, uma ferramenta de organização da "filla de espera" no serviço de saúde, para que aqueles usuários que precisam mais, sejam atendidos com prioridade, e não por ordem de chegada (Brasil, 2008) ${ }^{24}$.

Porém, o que vemos na prática do Acolhimento na UBS A" é o oposto do preconizado pela PNH.

Após realizarem um estudo da demanda espontânea das mulheres que passam pelo Acolhimento, as profissionais deste serviço, constataram que as pacientes solicitam: renovação de receitas, teste de gravidez e, principalmente, o que a equipe nomeou nas entrevistas de "escuta". As demandas de renovação de receita são direcionadas às médicas, os testes de gravidez são realizados pela equipe de enfermagem e consequente a abertura do prénatal, e a escuta?

24 Dicas em Saúde - Acolhimento, 2008 Nov. [Internet] [citado 09 de maio.2018]. Disponível em: http://bvsms.saude.gov.br/bvs/dicas/167acolhimento.html 
Há certa "pressa" das enfermeiras em realizar esta triagem, uma vez que a determinação das faltas nas consultas médicas do dia ocorre a cada hora, que são chamadas "blocos". Todas as pacientes são agendadas por hora (6 pacientes por hora na agenda da médica) e vão sendo atendidas por ordem de chegada (organizada pela recepção). Caso 6 pacientes recebam como horário de consulta 9h00, por exemplo, serão orientados a chegar com antecedência mínima de 30 minutos e deverão ser atendidas por ordem de chegada. Assim, às $8 \mathrm{~h} 50$ já é possível saber quantas pessoas faltaram no "bloco das 9h00" das agendas de todas as profissionais médicas da UBS. Nas agendas das médicas há também algumas vagas disponíveis previamente para "encaixes". Assim, temos uma grande "loteria" de vagas, sem garantia de atendimento pela profissional de referência. $\mathrm{O}$ que dificulta o cumprimento de um princípio da Atenção Básica que é a longitudinalidade do cuidado.

As enfermeiras entrevistadas relatam grande angústia em terem que lidar com a "escuta", por não se sentirem preparadas e por reconhecerem que este tipo de abordagem leva mais tempo do que elas têm disponível no Acolhimento, devido à pressa para contemplar as vagas de faltas dos "blocos". De acordo com estas profissionais, o conteúdo das falas das mulheres no Acolhimento, parece ser em sua base o mesmo trazido durante o exame de papanicolau - relações abusivas, dificuldades familiares, vulnerabilidade social, violência de gênero. Qual seria diferença entre estes momentos?

No papanicolau há um protocolo de orientação da prática do exame. As perguntas a serem direcionadas à paciente circunscrevem as possibilidades de respostas. Por esse motivo as enfermeiras afirmam se sentirem mais seguras para acolher o que aparece e indicam a pergunta sobre "a primeira relação sexual" como importante disparador para os relatos das histórias de vida. Neste momento, muitas mulheres trazem diversas situações de violência de gênero que viveram ou vivem.

Apesar de apontarem certo desconforto, as enfermeiras sentem-se mais seguras em "escutar" durante o exame de papanicolau, pois o objeto de intervenção eleito - o exame, e sua realização ou não de acordo com critérios de eletividade - foi contemplado. Assim, a escuta aparece como um "bônus" da intervenção. Já no Acolhimento, o objeto de intervenção eleito pela enfermagem é a "escuta", objeto este que não é direcionado à sua profissão e portanto, não é contemplado em sua formação profissional. Além da formação, as enfermeiras compreendem que o que mais dificulta é a falta de tempo para propiciar um espaço de escuta mais cuidadoso. 
De acordo com o Caderno AB 34, possibilitar o desabafo é uma das principais ferramentas de cuidado na $\mathrm{AB}$.

Por vezes o usuário não se dá conta da relação de seus conflitos e seus sofrimentos com aquilo que ele fala, pensa ou faz. Ter o profissional de Saúde da Atenção Básica como um interlocutor pode ser uma via para lidar com esses sofrimentos cotidianos, muitas vezes responsáveis por somatizações ou complicações clínicas. O exercício de narrar seus sofrimentos, ter a possibilidade de escutar a si mesmo enquanto narra, além de ser ouvido por um profissional de Saúde atento, por si só, já pode criar para o usuário outras possibilidades de olhar para a forma como se movimenta na vida e suas escolhas, além de também ofertar diferentes formas de perceber e dar significado aos seus sofrimentos. Outras vezes, caberá ao profissional de Saúde, a partir daquilo que ouviu ou percebeu, devolver ao paciente algumas ofertas para lidar com situações que aumentam o sofrimento. A segurança para realizar estas orientações virá do vínculo produzido com o usuário ao longo do tempo. Cabe destacar que isso é possível justamente porque o profissional de Saúde se dispôs e soube se colocar como este interlocutor (Brasil, 2013, p.24).

O texto reforça que, por ser uma atitude comum no dia a dia das pessoas, a escuta do desabafo é uma ferramenta desvalorizada, pois compreende-se que o cuidado em saúde mental deva ser algo mais "técnico". Como também foi enfatizado no texto, o vínculo com as pessoas de quem cuidamos, é mais facilmente garantido em uma relação de alguns encontros entre os sujeitos, e ainda, pode propiciar que a trabalhadora de saúde sinta-se mais segura em escutar e propor estratégias de cuidado efetivas, com sentido para as mulheres e para as pessoas de quem cuidam, de forma geral.

Conforme apresentado acima, o trabalho nesta UBS está organizado de forma que dificulta a vinculação e a longitudinalidade do cuidado. Portanto, não raramente as profissionais se sentirão inseguras em propor estratégias de cuidado que, muitas vezes, implicariam em auxiliar as mulheres em processos de tomada de consciência de suas condições de vida. Pois seria leviano, como demonstrado pela entrevistada E1, promover esta problematização das condições de vida e não acompanhar esta mulher neste processo.

Esta desvalorização da escuta apareceu em diversos relatos das trabalhadoras entrevistadas. Inclusive a maneira de compreender o Grupo de Mulheres como "o" espaço de escuta denota esta compreensão da indispensabilidade de um "especialista" em escutar. Porém, para que se compreenda as necessidades ampliadas de saúde das mulheres, é preciso que os profissionais escutem e incorporem em suas práticas a perspectiva de que a saúde mental das mulheres depende das questões de gênero, somadas às condições socioeconômicas e culturais (MS, 2004, pg.46).

Pensar em gênero e saúde mental não é apenas pensar no sofrimento causado pelos transtornos mentais que acometem as mulheres, ou então nas 
tendências individuais que algumas mulheres apresentam em desencadear crises e depressões. Antes de tudo, é necessário contextualizar os aspectos da vida cotidiana das mulheres, conhecer com que estrutura social contam ou não, para resolver as questões práticas da vida, e reconhecer que a sobrecarga das responsabilidades assumidas pelas mulheres tem um ônus muito grande, que muitas vezes se sobrepõe às forças de qualquer pessoa (Brasil, 2004, p.45).

Neste sentido, o Grupo de Mulheres é apontado como uma proposta de cuidado eficaz para as necessidades de saúde que as mulheres apresentam, pois fomenta a problematização das condições de vida e das questões de gênero, além de acompanhar as mulheres neste processo de conscientização. A determinação social das necessidades e das condições de vida são objeto de trabalho no Grupo.

No caso das mulheres, que culturalmente têm seu gênero associado à ausência de autonomia, à fragilidade, ao descontrole emocional e à menor capacidade de produção em relação aos homens (entre outras construções homogeneizantes sobre os gêneros), o dispositivo grupal pode causar rupturas nessas subjetividades femininas que, cada uma à sua maneira, foram formatadas pelas estruturas capitalistas de produção subjetiva. Os grupos de mulheres têm sido uma estratégia utilizada desde o início do movimento feminista para trabalhar questões de gênero [...] Os grupos representam um caminho para a construção de estratégias coletivas de resistência para as mulheres (Sá et. al, 2015, p. 91).

Em relação às participantes do Grupo de Mulheres, seu perfil corrobora com os dados sociodemográficos do território, conforme apresentado anteriormente (seção 3.2.1 Histórico do território e alguns dados sociodemográficos). A maioria das participantes é negra, jovemadulta, não possui emprego formal e muitas sobrevivem com recursos públicos como o BolsaFamília. As situações de violência doméstica e de gênero são bastante comuns entre estas mulheres e muitos dos seus sofrimentos são decorrentes de suas condições de vida.

Nos chamados grupos de mulheres, podemos dizer que há uma impossibilidade em se generalizar as diferentes respostas que as mulheres constroem, as diferentes demandas, expectativas, desejos, necessidades ao longo de sua existência: questões relacionadas ao corpo, as relações com os filhos, cônjuges, com os processos de amadurecimento, envelhecimento, as questões ligadas ao trabalho doméstico e ao trabalho fora de casa, lazer, atividades cotidianas e toda uma gama de problematizações que emergem quando mulheres conversam e de fato pode, ter uma escuta significativa (Liberman et. al25, 2009, apud Sá et. al, 2015, p. 90).

25 Liberman F et al. Cartografias femininas: a constituição de um Grupo de Mulheres na zona noroeste - Santos. Santos (texto digitado); 2009. 
Então, fica claro o motivo de angústia das trabalhadoras diante das problemáticas da determinação social que as mulheres apresentam, pois o sistema de saúde não organizou respostas complexas o suficiente para lidar intersetorialmente com tais necessidades.

Porém, para além da estratégia do Grupo, que outras formas de organização do trabalho seriam possíveis para garantir a escuta qualificada?

As profissionais apontam que ao buscarem a UBS, qualquer que seja a demanda, as mulheres sempre buscam "escuta". Assim, uma das estratégias utilizadas para dar conta dessa demanda foi aumentar o tempo da consulta de coleta do exame de papanicolau, bem como oferecer "acesso livre" às mulheres consideradas "mais problemáticas" para que procurassem a referida profissional quando necessitassem desabafar. Porém, estas foram estratégias de organização individual das trabalhadoras. Outra estratégia encontrada, em determinado momento, foi solicitar ao NASF que se organizasse como "escutador", para onde seria direcionada esta demanda muito frequente no Acolhimento. A equipe NASF problematizou esta questão e propôs estar junto nos períodos do Acolhimento, a fim de entender esta solicitação.

Vale destacar a importância de transformação dos aparatos político-institucionais de saúde, pois a organização do trabalho influencia diretamente a relação das profissionais com as pacientes.

A relação médico-paciente [profissionais de saúde-paciente] recebe influências de aspectos gerenciais do sistema, organizacionais da unidade de saúde, da formação do médico [da profissional] e da pessoa [...] Frequentemente se aponta a questão da formação como uma conquista a longo prazo, que mantém os gestores em condição mais confortável e pressupõe a relação médico-paciente como resultado de um encontro descontextualizado e a-histórico entre duas pessoas. É claro que o projeto formativo tem que estar vinculado a mudanças nos aspectos estruturais, gerenciais e organizacionais das unidades de saúde para articular avanços tecnológicos e acolhimento, melhores condições de trabalho e processos comunicacionais (Deslandes ${ }^{26}$, 2004, apud Caprara; Franco, 2006, p.99).

As autoras, Caprara e Franco (2006), compreendem a importância de investimentos na formação dos profissionais de saúde, como uma das alternativas. Porém, ressalvam que intervir somente sobre "os que estão na ponta" é uma "falácia" dos discursos sobre a humanização da assistência (p.100). Ou seja, muito além de inserir algumas disciplinas de humanidades e estágios na $\mathrm{AB}$ e no SUS, e até mesmo uma reforma dos Projetos Político-

26 Deslandes SF. Análise do discurso oficial sobre a humanização da assistência hospitalar. Ciência Saúde Coletiva. 2004; 9(1): 7-14. 
Pedagógicos dos cursos de saúde, é necessário haver "mudanças nos aspectos gerenciais e organizacionais dos serviços de saúde, assim como nas estruturas físicas” (p.104).

Além do questionamento do modelo de assistência e consequente organização do trabalho, bem como dos limites da formação das profissões de saúde, foi constatada certa contradição entre a prática profissional, que se mostra majoritariamente reducionista, e o discurso proferido pelas profissionais nas entrevistas. Todas as trabalhadoras entrevistadas compreendem a Saúde da Mulher como algo complexo, que requer uma prática de cuidado integral.

Ao falarem de Saúde da Mulher, as trabalhadoras apontam que as práticas de assistência ofertadas por elas são: consultas de papanicolau, grupos de mamografia, grupo de Planejamento Familiar e consultas de pré-natal. Ou seja, estratégias voltadas somente para a Saúde Reprodutiva, que contradizem a maneira como as próprias trabalhadoras compreendem a integralidade da Saúde da Mulher. Todas as trabalhadoras entrevistadas nomeiam o Grupo de Mulheres como uma estratégia da linha de cuidado de saúde da mulher. E a maioria delas considera que o principal objetivo do Grupo é "empoderar" as mulheres.

Santos e Lemos (2011) problematizam as práticas de empoderamento de mulheres que é um viés adotado por políticas públicas, Organizações Não Governamentais (ONG) e movimentos sociais desde a década de 1990 no Brasil. De acordo com as autoras, estas práticas compreenderiam o empoderamento como uma forma de poder que poderia ser transferido às mulheres por meio de conscientização. Tais práticas pressupõem a opressão de outro grupo, no caso, os homens ou o patriarcado. Utilizando-se da discussão de genealogia do poder de Foucault, as autoras colocam "em xeque posicionamentos que se apoiam em esquemas binários, que fixam identidades sexuais, ao prescrever os modos como homens e mulheres 'devem ser"” (p. 408-9). Ou seja, "as relações de poder deveriam ser vistas sob um prisma relacional, em que forças de resistência e dominação se mobilizariam constantemente, atravessando todos os corpos" (p. 409). Desta forma, mais do que opressão e abuso, há também nas relações de poder, produtividade e resistência. Portanto, tais relações são sempre reversíveis, e o poder não se configura como propriedade de um sexo, etnia, classe social ou Estado - "as relações de poder são exercidas e não possuídas" (Santos e Lemos, 2011, p. 409).

As práticas de empoderamento parecem reforçar que o "homem tem poder sobre a mulher". E desta forma, as mulheres "não possuem poder" e deveriam ser "empoderadas", o que condiz com o pensamento da segunda onda feminista. Ao considerar a terceira onda do 
feminismo, as autoras reforçam que é necessário superar o sexismo e as dicotomias, considerando as multiplicidades dos sujeitos.

Apesar da crítica a este movimento restrito à conscientização, Santos e Lemos (2011) não sugerem estratégias para fomentar os "processos de subjetivação". Mesmo assim, a argumentação destas autoras nos auxilia a questionar a maneira como algumas profissionais parecem "prescrever" o empoderamento e o que vem a ser "a mulher empoderada", baseandose nas próprias experiências, sem considerar a multiplicidade dos modos de viver. Ou seja, desejar que as mulheres deste território não sejam mães jovens e decretar luta contra a gravidez na adolescência, não significa necessariamente trabalhar pela autonomia destas mulheres. Mas configura-se como uma forma de julgamento deste modo de viver como negativo, que deve ser combatido, em que o referencial de modo de viver ideal seja o próprio.

Mesmo algumas Políticas Públicas tendo intenções emancipatórias, elas também estão carregadas de valores sociais, morais e culturais. Assim, as trabalhadoras de saúde devem estar atentas às suas práticas, aos próprios valores e às reais necessidades de saúde das mulheres de quem cuidam. Em pesquisa de campo, D’Oliveira e Schraiber (1999) observaram

o quanto do mundo real das pacientes não correspondia aos modelos ideológicos que o programa [PAISM] preconiza: a mulher moderna, independente, que dialoga com o parceiro e exige seus direitos. Como observaram, muitas usuárias não queriam questionar seus companheiros, pois deles dependiam. Outras, por não problematizarem as hierarquias de gênero e a divisão sexual do trabalho, não sentiam necessidade de transformar suas relações (D’Oliveira; Schraiber ${ }^{27}, 1999$ apud Barbosa, 2006, p.330).

Trabalhar no sentido de propiciar o auto-empoderamento, é trabalhar forjando possibilidades para que as mulheres possam falar por si mesmas, e para que melhorem suas capacidades de negociação e suas habilidades de exercer controle sobre suas vidas. Assim, havemos de questionar também o lado produtivista e moralizador do trabalho e da família: aspectos amplamente incorporados e naturalizados nos processos terapêuticos. É também de grande importância reconhecer as diversas necessidades e respeitar as diferenças entre as mulheres (Testa e Spampinato, 2000).

27 D’Oliveira AFP, Schraiber LB. Violências de gênero, saúde reprodutiva e serviços. In: Giffin K, Costa SH, organizadores. Questões de Saúde Reprodutiva. Rio de Janeiro: Editora Fiocruz; 1999. $468 \mathrm{p}$. 
Além do "empoderamento", houve profissionais que apontaram certa expectativa de que o Grupo de Mulheres tornasse as participantes mais "resilientes" perante as dificuldades da vida.

Consideramos que a saúde mental "se constitui ao tomar pra si a relação dos sujeitos consigo mesmos (mente e corpo), bem como com a natureza e com o social, isto é, com os outros e com as instituições humanas" (Campos, 2016, p.32). O seu objeto central são os "modos de vida das pessoas" com ênfase naqueles com "dificuldades de viver" (Dolto ${ }^{28}, 1989$ apud Campos, 2016, p.32).

Tomemos a eterna polêmica sobre se as práticas de saúde mental devem ter o objetivo de emancipar os sujeitos, de libertá-los de todo jugo ou, ao contrário, de adaptá-los ao respeito às leis e convenções sociais [...] Terapias para aumentar a resiliência ou para ampliar a capacidade de crítica e rebelião? Para fortalecer a individuação ou a integração ao coletivo? (Campos, 2016, p.33).

Podemos dizer que o Grupo de Mulheres localiza-se no meio desta polêmica. Pois, além das profissionais, as próprias mulheres participantes esperam uma solução rápida para as questões de sofrimento que apresentam. A solução esperada implicaria em resultados diversos: remissão total de sintomas; inclusão efetiva em mercado de trabalho; resoluções dos conflitos familiares; que as mulheres não mais buscassem outras profissionais da UBS, que não as coordenadoras do Grupo, para “desabafarem”. E nem sempre podemos observar tão rápida e claramente estes resultados.

Além disso, o Grupo de Mulheres se propõe a apoiar mulheres com "dificuldades de viver". Essa linguagem não é utilizada pelas profissionais da ESF, que nomeiam os sofrimentos das pessoas através dos diagnósticos. Assim, poucas profissionais indicam o Grupo como estratégia de cuidado para as mulheres.

Além de todas estas dificuldades no que refere à formação e à prática profissional,

se atribui à rede de atenção especializada em saúde mental - centros de atenção psicossocial, centros de convivência, hospital geral e urgência, entre outros serviços - a responsabilidade pelos transtornos mentais graves. À ESF caberia lidar com todas as demais 'dificuldades de viver' ou com 'outros sofrimentos psíquicos', ou com 'distúrbios intermediários', usando algumas das classificações correntes. Parece-me um encargo excessivo para a APS; além disso, esse arranjo organizacional é um sintoma da tendência a subestimar, se não a negar, a relevância dos problemas psíquicos considerados fora do grupo das psicoses (Campos, 2016, p.35).

28 Dolto F. Dificuldades de viver. Lisboa: Don Quixote; 1989. 368 p. 
Testa e Spampinato (2000) afirmam que, como agentes de saúde, devemos reconhecer as relações de poder que nos implicam e, portanto, influenciam a nossa prática profissional. As autoras destacam a natureza política das ocupações e dos espaços da cotidianeidade e o poder de transformação das atividades humanas como possibilidades para influenciar o social. Desta forma, "as ocupações e o cotidiano tanto podem ser o meio invisível, eficaz e sutil para reproduzir as relações estabelecidas, como o meio para desafiar os limites do que é possível para incrementar e potencializar as liberdades". Então, para "desafiar os limites e potencializar liberdades" é preciso primeiramente desnaturalizar e, depois, questionar as lógicas binárias instituídas.

Enaltecemos a necessidade de constituição de outra subjetividade profissional, aberta ao diálogo e a assumir compromissos com a saúde das usuárias dos serviços de saúde (Campos, 1999). Portanto, profissionais mais preparadas para escutar, acolher e cuidar das situações de sofrimento apresentadas pelas mulheres. Sendo o trabalho em equipe a base da ESF, reiteramos a relevância da Prática Interprofissional (PIP) e da Educação Interprofissional (EIP) em saúde para a transformação das práticas de cuidado.

Destacamos neste sentido a importância da presença da profissional de terapia ocupacional nas equipes interprofissionais da $\mathrm{AB}$ e ainda, na coordenação de Grupos de Mulheres. Pois, historicamente, "pessoas com dificuldades na realização de atividades cotidianas e na participação na vida social [...] se beneficiam das abordagens em terapia ocupacional [...] [e] os grupos são instrumentos potentes de experimentação de convivência social" (Nicolau, 2015, p.269).

Assim, voltamos à pauta que abriu esta discussão, sobre a influência do Neoliberalismo na organização da Saúde Pública e questionamos: à quem interessa assolar a $\mathrm{AB}$ e suas trabalhadoras de metas e demandas? À quem interessa o corte de verbas à saúde e a consequente diminuição do quadro de profissionais? À quem interessa a formação das profissionais com foco no tecnicismo? À quem interessa manter na mesma UBS dois modelos de $\mathrm{AB}$ diferentes?

Com certeza, não falamos dos interesses da população assistida e dependente do SUS. Mas apesar dos limites da nossa prática profissional perante todo este cenário, há possibilidades de resistência e de cuidado, embasadas pelo paradigma da clínica ampliada. É o que se tenta fazer na proposição do Grupo de Mulheres. 


\section{CONSIDERAÇÕES FINAIS}

A equipe NASF A vem sendo acionada majoritariamente para o cuidado de mulheres com questões de sofrimentos comuns. Porém, percebe-se que muitas destas situações são classificadas como transtornos mentais comuns e até severos. Havendo, portanto, intensa patologização do sofrimento e do cotidiano.

Utilizando-se do discurso biomédico e da perspectiva de necessidade de atendimento especializado em que foram formadas, não há por parte das profissionais uma escuta mais aprofundada. Por não serem genuinamente da área da Saúde Mental, direcionam pedidos de atendimentos para os profissionais deste campo, mais especificamente para a psicologia e para a psiquiatria do NASF.

As profissionais da UBS A" relatam dificuldades em lidar com o sofrimento das pessoas, não compreendendo quais os recursos que possuem para o cuidado. Justificam tais dificuldades dizendo que receberam pouca ou nenhuma formação a este respeito. Compreendem também que a organização do processo de trabalho e a lógica de funcionamento da $\mathrm{AB}$ não favorecem para que estejam mais disponíveis a uma escuta cuidadosa das questões apresentadas pelas mulheres.

De forma geral, nesta UBS, a "Saúde da Mulher" parece se restringir às ações estratégicas mínimas, mesmo com a incorporação da ESF e do NASF. Ou seja, de acordo com as exigências e metas colocadas pela Gestão, a equipe da ESF organiza seu trabalho voltado para as prioridades de saúde reprodutiva e demandas da linha de cuidado materno-infantil. Assim, acabam solicitando apoio da equipe NASF A em diversas situações de sofrimento manifestado pelas mulheres, sem tentarem as próprias intervenções. Esse processo coloca em questão o apoio matricial e reitera a lógica dos encaminhamentos no esquema de referência/contra-referência.

Através das entrevistas das trabalhadoras e usuárias, o Grupo de Mulheres é reconhecido como estratégia eficaz de cuidado das necessidades ampliadas de saúde das mulheres deste território. Porém, as trabalhadoras compreendem que utilizam pouco este recurso para compor os PTS das mulheres de quem cuidam. Parece que este dispositivo grupal tem sido usado na lógica dos encaminhamentos, fato denotado pelo pequeno número de mulheres que chegam ao grupo orientadas por profissionais que não componham o NASF. 
Mesmo ao encaminhar as mulheres para o Grupo, é preciso responsabilização por este processo. As profissionais têm oferecido o Grupo às mulheres sob a forma de encaminhamentos. Não agendam um retorno e também não explicam mais apropriadamente sobre o funcionamento deste espaço. Assim, o que fica de registro é que o Grupo existe e que parece funcionar, mas as profissionais não se apropriam desta estratégia como forma de cuidado.

E para além do encaminhamento ao Grupo de Mulheres?

Ficou evidente que as questões de gênero são muito relevantes nos processos de adoecimento das mulheres deste território, mais especificamente como gênese dos sofrimentos apresentados por elas.

A partir de observação empírica, a prevalência de mulheres que utiliza o serviço da UBS A" é maior do que a de homens. O que corrobora com os dados apresentados pela PNAISM (MS, 2004, p.9) em que "as mulheres são a maioria da população brasileira $(50,77 \%)$ e as principais usuárias do Sistema Único de Saúde”. Além disso, apesar das mulheres viverem mais que os homens, elas adoecem mais frequentemente. Visto que, "a vulnerabilidade feminina frente a certas doenças e causas de morte está mais relacionada com a situação de discriminação na sociedade do que com fatores biológicos" (MS, 2004, p.9), a situação de desigualdade vivida pelas mulheres limita seu desenvolvimento e compromete a sua saúde mental (MS, 2004, pg.45).

As relações de gênero expressam-se por meio de interesses, recursos e relações de poder. Portanto, para atuar no sentido da não reprodução dos estereótipos de gênero e suas formas de opressão, se faz necessário reconhecer oportunidades e resistências tanto nas práticas quanto nos valores das trabalhadoras e da população atendida. É importante estar atentas às expressões de gênero nos modelos de assistência, nos dispositivos, nas relações terapeuta-paciente, na maneira como se identifica as necessidades das pacientes e no acesso aos direitos (quais direitos buscamos acessar e com qual propósito?).

Ressaltamos que não tivemos o intuito de produzir um estudo que generalizasse as mulheres e nem as práticas, pois "mesmo ao falar sobre o que se faz, por que se faz e como se faz, essa obra não assume uma função instrumental" (Galheigo, 2015, contra-capa). Assim, longe de traduzir a "verdade" sobre o modo de cuidar, este trabalho propõe uma maneira de fazer de acordo com as condições materiais daquele território. A própria condição da pesquisadora como trabalhadora do serviço e coordenadora do Grupo de Mulheres, locus da 
pesquisa, foi situação de grande desafio para a realização deste estudo. Porém, destacamos a importância deste trabalho no sentido de adensar o discurso das questões de gênero nas práticas de saúde. Algo que, como demonstrado nesta pesquisa, mostra-se de extrema relevância para o cuidado de mulheres na AB e no SUS de forma geral.

Com estes apontamentos, caminhamos então para a conclusão desta pesquisa com indicativos para a prática clínica e estudos futuros. 


\section{REFERÊNCIAS ${ }^{29}$}

Andrade D, Ishida, R, Jóia, JH, Trenche MCB. Implementação da rede de saúde na região da Freguesia do Ó e Brasilândia. In: Vicentin MCG, Trenche MCB, Kahhale EP.; Almeida IS, organizadores. Saúde Mental, Reabilitação e Atenção Básica: Encontros entre Universidade e Serviços de Saúde. São Paulo: Artgraph; 2016, p.33-52.

Aquino EML. Gênero e saúde: perfil e tendências da produção científica no Brasil. Rev Saúde Pública. 2006; 40:121-32. doi: 10.1590/S0034-89102006000400017.

Bandeira LM. Violência de gênero: a construção de um campo teórico e de investigação. Rev Sociedade Estado. 2014; 29(2): 449-69. doi: 10.1590/S0102-69922014000200008.

Barbosa RHS. Humanização da assistência à saúde das mulheres: uma abordagem crítica de gênero. In: Deslandes SF, organizador. Humanização dos cuidados em saúde: conceitos, dilemas e práticas. Rio de Janeiro: Editora Fiocruz; 2006. p. 323-50.

Brasil. Portaria GM n 399 , de 22 de fevereiro de 2006. Pacto pela Saúde - Consolidação do SUS. Diário Oficial da República Federativa do Brasil, Brasília; 2006.

Brasil. Portaria GM no 154, de 24 de janeiro de 2008. Cria os Núcleos de Apoio à Saúde da Família - NASF. Diário Oficial da República Federativa do Brasil, Brasília; 2008.

Brasil. Política nacional de atenção integral à saúde da mulher: princípios e diretrizes. Brasília: Ministério da Saúde; 2004.

29 De acordo com o Estilo Vancouver. 
Brasil. Cadernos de Atenção Básica, n. 27, série B - Diretrizes do NASF. Brasília: Ministério da Saúde; 2009.

Brasil. Política Nacional de Atenção Básica - PNAB. Brasília: Ministério da Saúde; 2012.

Brasil. Cadernos de Atenção Básica, n. 34 - NASF: Saúde Mental. Brasília: Ministério da Saúde; 2013.

Brasil. Cadernos de Atenção Básica, n. 39, vol. 1 - NASF: Ferramentas para a gestão e para o trabalho cotidiano. Brasília: Ministério da Saúde; 2014.

Campos GWS. Equipe de referência e apoio especializado matricial: um ensaio sobre a reorganização do trabalho em saúde. Ciência e Saúde Coletiva. 1999; 4(2): 393-403. doi: 10.1590/S1413-81231999000200013.

Campos CMS, Bataiero MO. Necessidades de saúde: uma análise da produção científica brasileira de 1990 a 2004. Interface - comunicação, saúde, educação. [Internet] 2007 Set-Dez [citado 15 de mai.2018]; 11(23):605-18. Disponível em:http://www.scielo.br/pdf/icse/v11n23/ a14v1123.pdf.

Campos GWS, Domitti AC. Apoio Matricial e Equipe de Referência: uma metodologia para a gestão do trabalho interdisciplinar em saúde. Cadernos de Saúde Pública. 2007; 23(2): 399407. doi: 10.1590/S0102-311X2007000200016.

Campos CMS. Reconhecimento das necessidades de saúde dos adolescentes. In: Borges ALV, Fujimori E, organizadores. Enfermagem e a saúde do adolescente na atenção básica. Barueri: Manole; 2009. p.142-67. 
Campos GWS. Saúde mental e atenção primária: apoio matricial e Núcleos de Apoio à Saúde da Família. In: Nunes M, Landim FLP, organizadores. Saúde mental na atenção básica: política e cotidiano. Salvador: EDUFBA; 2016. p.29-46.

Caprara A, Franco ALS. Relação médico-paciente e humanização dos cuidados em saúde. In: Deslandes SF, organizador. Humanização dos cuidados em saúde: conceitos, dilemas e práticas. Rio de Janeiro: Editora Fiocruz; 2006. p. 85-08.

Creswell JW. Investigação qualitativa e projeto de pesquisa: escolhendo entre cinco abordagens. Porto Alegre: Penso; 2014. Capítulo 4, Cinco abordagens qualitativas de investigação. p.67-96.

Deslandes SF. O projeto de pesquisa como exercício científico e artesanato intelectual. In: Minayo MCS, organizadores. Pesquisa Social: teoria, método e criatividade (28 a ed). Rio de Janeiro: Ed. Vozes; 2009. p. 31-60.

Favilli E, Cavallo F. Histórias de ninar para garotas rebeldes: cem fábulas sobre mulheres extraordinárias. Bitelli C, Yacubian F, Oliboni Z, tradutores. São Paulo: Vergara \& Riba Editoras; 2017. 220 p.

Galheigo S. Contra-capa. In: Maximino V, Liberman F. Grupos e terapia ocupacional: formação, pesquisa e ações. São Paulo: Summus; 2015.

Gil AC. Estudo de caso: fundamentação científica, subsídios para coleta e análise de dados, como redigir o relatório. São Paulo: Atlas; 2009. 148 p.

Godoy A, Costa RM, Sant'anna M, Gomes BR. Método. In: Godoy, A, Gomes BR, Sant'anna M, Costa RM, organizadores. Revista do I Fórum Estadual de Redução de Danos do Estado de São Paulo. São Paulo: Córrego; 2014. p.16-9. 
Lima EMFA. A análise de atividade e a construção do olhar do terapeuta ocupacional. Rev Terapia Ocupacional Univ São Paulo. 2004 Maio-Ago. 15(2): 42-8. doi: 10.11606/issn.22386149.v15i2p42-48.

Lima EMFA, Okuma DG, Pastore MN. Atividade, ação, fazer e ocupação: a discussão dos termos na Terapia Ocupacional brasileira. Cad Terapia Ocupacional Univ Federal São Carlos. 2013. 21(2): 243-54. doi: 10.4322/cto.2013.026.

Lins BA, Machado BF, Escoura M. Diferentes, não desiguais: a questão de gênero na escola. São Paulo: Editora Reviravolta; 2016. 144 p.

Martins E. The Egg and the Sperm: how science has constructed a romance based on stereotypical male-female roles. J Women Culture Society. 1991; 16(3): 485-501. doi: abs/10.1086/494680.

Maximino V, Liberman F. Grupos e Terapia Ocupacional: formação, pesquisa e ações. São Paulo: Summus; 2015. Capítulo 1, Cenas em formação: buscando na prática os pressupostos para o que fazemos; p.10-26.

Merhy EE. O conhecer militante do sujeito implicado: o desafio em reconhecê-lo como saber válido. In: Franco BT, Peres MAA, Foschiera MMP, Panizzi M, organizadores. Acolher Chapecó: uma experiência de mudança do modelo assistencial, com base no processo de trabalho. São Paulo: Hucitec; Chapecó, SC; Prefeitura Municipal; 2004. p.21-45.

Minayo MCS. O desafio do conhecimento: pesquisa qualitativa em saúde. São Paulo: Hucitec; 2004. 269 p. 
Nicolau SM. Grupos na Atenção Básica: enraizar-se em uma comunidade. In: Maximino V, Liberman F. Grupos e Terapia Ocupacional: formação, pesquisa e ações. São Paulo: Summus; 2015. p.264-74.

Peduzzi M, Norman IJ, Germani ACCG, Silva JAM, Souza GC. Educação Interprofissional: formação de profissionais de saúde para o trabalho em equipe com foco nos usuários. Rev Escola Enfermagem Univ São Paulo. 2013; 47(4):977-83. doi: 10.1590/S0080623420130000400029 .

Quintanilha EL. Cuidado em saúde mental pelo programa de saúde da família: análise qualitativa de uma terapia de grupo para mulheres. [dissertação] [Internet]. Rio de Janeiro: Universidade do Estado do Rio de Janeiro, Faculdade de Ciências Médicas; 2014 [citado 24 de mai.2018]. Disponível em: http://www.bdtd.uerj.br/tde_busca/arquivo.php? codArquivo=7476.

Rosa SD, Brançam GS. A intervenção grupal como recurso da terapia ocupacional: uma experiência com mulheres climatéricas. Cad Terapia Ocupacional Univ Federal São Carlos. 2013; 21(2):423-28. doi: 10.4322/cto.2013.044.

Rosa EZ, Pinto RS, Vicentin MCG, Silva DAB. O território sanitário da Freguesia do Ó/Brasilândia e o lugar do território na integração ensino-serviço. In: Vicentin, MCG, Trenche MCB, Kahhale EP, Almeida I, organizadores. Saúde Mental, Reabilitação e Atenção Básica: Encontros entre Universidade e Serviços de Saúde. São Paulo: Artgraph; 2016. p.53-78.

Sá Y, Liberman F, Maximino V, Garcia ML. Cartografias femininas: Grupo de mulheres pelo olhar dos estudantes. In: Maximino V, Liberman F. Grupos e Terapia Ocupacional: formação, pesquisa e ações. São Paulo: Summus; 2015. p.88-114. 
Sampaio J, Sousa CSM, Marcolino EC, Magalhães FC, Souza FF, Rocha AMO, Neto AAS, Sobrinho GDO. O NASF como dispositivo da Gestão: limites e possibilidades. Rev Bras Ciências Saúde. 2012; 16(3):317-24. doi: 10.4034/RBCS.2012.16.03.06.

Santana JP, Campos FE, Sena RR. Formação profissional em saúde: desafios para a universidade. Texto de apoio elaborado especialmente para o Curso de Especialização em Desenvolvimento de Recursos Humanos de Saúde - CDRHU. [Internet] 1999; [citado 16 de mai.2018]. Disponível em: http://www.opas.org. br/rh/publicacoes/textos_apoio/ ACF2114.pdf.

Santos DV, Lemos FCS. Uma analítica da produção da mulher empoderada. Psicologia Sociedade, 2011. 23(2): 407-14. doi: 10.1590/S0102-71822011000200022.

São Paulo. Diretrizes e Parâmetros norteadores das ações dos NASF. São Paulo: Secretaria Municipal de Saúde [Internet] [citado 28 de abr.2015]. Disponível em: http://www.prefeitura. sp.gov.br/cidade/secretarias/upload/saude/arquivos/esf/diretrizes_nasf.pdf.

São Paulo. Mapa das Unidades de Saúde de Rede Municipal por Coordenadoria Regional de Saúde e Subprefeitura do Município de São Paulo. São Paulo: Secretaria Municipal de Saúde. [Internet] [citado 01 de mai.2016]. Disponível em: http://www.prefeitura.sp.gov.br/ cidade/secretarias/saude/epidemiologia_e_informacao/producao_e_rede_assistencial index.php? $=30566$.

Silveira DT, Córdova FP. A pesquisa científica. In: Gerhadt TE, Silveira DT, organizadores. Métodos de pesquisa. Porto Alegre: Editora da UFRGS; 2009. p.31-43.

Soares ALR, Vedoin CB, Silveira HS, Schio L. Alternativa metodológica para trabalhar gênero em sala de aula. Aedos - Revista do corpo discente do PPG-História da UFRGS [Internet]. 2015 Jul [citado 15 de mai.2018]; 7(16):22-35. Disponível em: http://seer.ufrgs.br/index.php/aedos/article/view/57005/34343. 
Souza DP, Cararo A. Extraordinárias mulheres que revolucionaram o Brasil, São Paulo: Seguinte; 2017. 208 p.

Testa DE, Spampinato SB. Género, salud mental y Terapia Ocupacional: algunas reflexiones sobre la influencia de la historia de las mujeres y la perspectiva de género em nuestras prácticas. Rev Terapia Ocupacional Univ São Paulo. 2010; 21(2):174-81. doi: 10.11606/issn.2238-6149.v21i2p174-181.

Vieira EM. A medicalização do corpo feminino. 1 ${ }^{\mathrm{a}}$.ed. Rio de Janeiro: Editora Fiocruz; 2002. 84 p.

Vicentin, MCG, Trenche MCB, Kahhale EP, Almeida I, organizadores. Saúde Mental, Reabilitação e Atenção Básica: Encontros entre Universidade e Serviços de Saúde. São Paulo: Artgraph; 2016. 206 p.

"Pai" da ginecologia moderna fez experiências com escravas negras. A sua estátua foi agora retirada do Central Park, 2018 Abr. [Internet] [citado 15 de mai.2018]. Disponível em: https://www.publico.pt/2018/04/20/mundo/noticia/estatua-do-pai-da-ginecologia-modernaretirada-do-central-park-1811113. 
APÊNDICE A - Resumo das histórias de mulheres brasileiras extradiordinárias

\begin{abstract}
ANITA GARIBALDI
Anita nasceu em 1821, em Laguna (Santa Catarina) e morreu na Itália, em 1849. Foi companheira de Giuseppe Garibaldi e lutou ao seu lado na Guerra dos Farrapos (1835-45). Era "uma mulher valente, apaixonada, de espírito independente, que sabia cavalgar muito bem e manejar armas como poucos soldados”. Em pleno século XIX, largou um casamento infeliz e foi se arriscar em lutas armadas, sendo protagonista de fugas espetaculares. Virou uma lenda no Brasil e na Itália, e ganhou o título de "heroína de dois mundos" (Souza; Cararo, 2017, p.44).
\end{abstract}

\title{
CORA CORALINA
}

Cora nasceu em 1889 e faleceu com 95 anos, tendo sido poetisa com 60 anos. Sua família não queria mandá-la para o ensino médio; eles achavam que ela deveria se preocupar apenas em "encontrar um bom marido e formar uma família". Ela se casou, teve 4 filhos e fez de tudo para mantê-los na escola. Mesmo sem apoio, escrevia todos os dias para si mesma. Quando já idosa, "decidiu que era hora de começar sua carreira como poetisa" e vendia bolos e tortas para se sustentar. Com 75 anos publicou o seu primeiro livro (Favilli; Cavallo, 2017, p.42).

\section{DANDARA}

Dandara, a rainha do Quilombo dos Palmares e companheira de Zumbi, morreu em 1694, na União dos Palmares (Alagoas). Foi "uma guerreira negra que aprendeu a fabricar espadas e a lutar com elas; uma capoeirista forte e corajosa que planejava ações de combate e liderava seus companheiros na luta pela liberdade”. Não há registros oficiais sobre seu nascimento e de como chegou "ao maior e mais duradouro quilombo" das Américas. Mas "quando se fala de Dandara, se coloca em questão o silêncio e o apagamento imposto às mulheres negras no Brasil” (Souza; Cararo, 2017, p.16).

\section{NISE DA SILVEIRA}

Nise, a psiquiatra do inconsciente, nasceu em Maceió (Alagoas), em 1905, e faleceu em 1996, no Rio de Janeiro (Rio de Janeiro). Ficou presa por oito anos, por ter livros marxistas, e isso 
mudou sua visão de mundo e de clínica. "Enquanto o mundo considerava o eletrochoque e a lobotomia os melhores tratamentos para os pacientes psiquiátricos, Nise só conseguia enxergar horror. Ela tinha uma visão muito mais humana, acolhedora, abrangente”. Por sua visão e por ser mulher em uma área de maioria masculina, foi ridicularizada e sabotada pelos colegas. Mesmo assim, ressignificou o setor de Terapêutica Ocupacional num hospital psiquiátrico, em que tratava os pacientes através da arte, tenho sido reconhecida mundialmente por este trabalho (Souza; Cararo, 2017, p.88). 
APÊNDICE B - Roteiro de entrevista: profissionais da ESF

1. Dados Pessoais

Nome:

Data de Nascimento:

Estado civil: (solteira, casada, união estável, separada, viúva)

Renda atual:

Profissão: $\quad$ Ano de formação:

Pós-graduação:

Qual o cargo atual e quanto tempo de atuação?

\section{Contextualizando}

Conte-me da sua trajetória profissional.

(escolha do curso, estágios realizados, pós-graduação, como chegou no cargo atual)

\section{Investigando}

O que é pra você Saúde da Mulher?

Quais estratégias na área da Saúde da Mulher você realiza? Qual a sua opinião sobre tais atividades?

Quais estratégias na área da Saúde da Mulher acontecem na UBS A"? Qual a sua opinião sobre tais atividades?

O que você acha que falta para atender a Saúde da Mulher? Que outras estratégias são necessárias?

\section{Refletindo}

Conte-me sobre o Grupo de Mulheres. Qual a sua opinião sobre esta atividade? Explique o que você entende que é realizado neste espaço (concepção da proposta e seus objetivos, funcionamento, estratégias utilizadas, perfil das participantes, avaliação e resultados da proposta)

Você notou alguma mudança nas necessidades das mulheres que participaram do Grupo?

O que você esperava de resultados do Grupo?

5. Considerações finais: Você gostaria de acrescentar algo? 
APÊNDICE C - Roteiro de entrevista: coordenadoras de NASF DE NASF

1. Dados Pessoais

Nome:

Data de Nascimento:

Estado civil: (solteira, casada, união estável, separada, viúva)

Renda atual:

Profissão: $\quad$ Ano de formação: Pós-graduação:

Qual o cargo atual e quanto tempo de atuação?

2. Contextualizando:

Conte-me da sua trajetória profissional.

(escolha do curso, estágios realizados, pós-graduação, como chegou no cargo atual)

\section{Investigando}

O que é pra você Saúde da Mulher?

Quais estratégias na área da Saúde da Mulher você realiza? Qual a sua opinião sobre tais atividades?

Quais estratégias na área da Saúde da Mulher os NASF sob sua supervisão realizam? Qual a sua opinião sobre tais atividades?

Quais estratégias na área da Saúde da Mulher acontecem na UBS A"? Qual a sua opinião sobre tais atividades?

O que você acha que falta para atender a Saúde da Mulher? Que outras estratégias são necessárias?

\section{Refletindo}

Conte-me sobre o Grupo de Mulheres. Qual a sua opinião sobre esta atividade? Explique o que você entende que é realizado neste espaço (concepção da proposta e seus objetivos, funcionamento, estratégias utilizadas, perfil das participantes, avaliação e resultados da proposta).

O que você esperava de resultados do Grupo?

Você sente haver dificuldades para a realização destes trabalhos? E potencialidades?

5. Considerações finais: Você gostaria de acrescentar algo? 
APÊNDICE D - Roteiro de entrevista: usuárias

\section{Dados Pessoais}

Nome:

Data de Nascimento:

Escolaridade:

Profissão:

Residência: (Própria? Mora com quem?)

Renda familiar: (Quanto e quem trabalha?)

Filhos: (Quantos? Qual a idade deles? Qual a sua idade no parto?)

Estado civil: (solteira, casada, união estável, separada, viúva)

\section{Contextualizando}

Conte-me da sua história de vida.

\section{Investigando}

O que é pra você Saúde da Mulher?

Quais estratégias na área da Saúde da Mulher acontecem na UBS A"? Qual a sua opinião sobre tais atividades?

As estratégias de Saúde da Mulher contemplam as suas necessidades? Você sugere outras? Se sim, porque? Se não, porque quais sugestões?

\section{Refletindo}

Conte-me como você chegou no Grupo de Mulheres e sobre sua experiência neste grupo.

Conte-me quais são as suas estratégias de cuidado para consigo mesma.

5. Considerações finais

Você gostaria de acrescentar algo? 
APÊNDICE E - Roteiro de entrevista: profissionais do NASF

\section{Dados Pessoais}

Nome:

Data de Nascimento:

Estado civil: (solteira, casada, união estável, separada, viúva)

Renda atual:

Profissão:

Ano de formação:

Pós-graduação:

Qual o cargo atual e quanto tempo de atuação?

\section{Contextualizando}

Conte-me da sua trajetória profissional.

(escolha do curso, estágios realizados, pós-graduação, como chegou no cargo atual)

\section{Investigando}

O que é pra você Saúde da Mulher?

Quais estratégias na área da Saúde da Mulher você realiza? Qual a sua opinião sobre tais atividades?

Quais estratégias na área da Saúde da Mulher acontecem na UBS A"? Qual a sua opinião sobre tais atividades?

O que você acha que falta para atender a Saúde da Mulher? Que outras estratégias são necessárias?

\section{Refletindo}

Conte-me sobre o Grupo de Mulheres. Qual a sua opinião sobre esta atividade?

(concepção da proposta e seus objetivos, funcionamento, estratégias utilizadas, perfil das participantes, avaliação e resultados da proposta)

\section{Considerações finais}

Você gostaria de acrescentar algo? 
APÊNDICE F - Termo de Consentimento Livre e Esclarecido: usuárias

Olá, meu nome é Juliana Russo Antunes, com registro profissional CREFITO 3/13494-TO, e sou mestranda na Universidade de São Paulo. O nome do Programa é Mestrado Profissional Interunidades de Formação Interdisciplinar em Saúde e assim, devo atuar como pesquisadora, estudando a realidade e escrevendo uma pesquisa. Uma professora acompanha e orienta o meu trabalho: Fátima Oliver, com registro profissional CREFITO 3/455-TO

O tema da minha pesquisa é "O cuidado de mulheres em um serviço de Atenção Básica: problematização de uma experiência de trabalho interprofissional" e eu pretendo entrevistar profissionais e usuárias da UBS A" para entender como acontece o cuidado de mulheres e as necessidades encontradas na prestação deste cuidado, no intuito de propor melhorias para o serviço.

Você está sendo convidada a participar voluntariamente desta pesquisa por ser usuária do serviço, participante do Grupo de Mulheres e porque acredito que tenha muito a contribuir neste estudo. Outras 5 mulheres do Grupo também serão convidadas. Serão feitas perguntas sobre sua história de vida e sobre as atividades que participa nesta UBS. A entrevista será gravada e posteriormente transcrita. Há um risco mínimo de que as perguntas venham a lhe causar algum desconforto e constrangimento. Para diminuir esse risco, a entrevista será conduzida de forma a criar um ambiente agradável para que se sinta confortável. Você poderá responder somente o que lhe for conveniente, interromper a sua participação se considerar necessário, além disso, lhe será ofertada assistência neste serviço. Além da entrevista, também é proposta uma pesquisa no seu prontuário nesta UBS.

Você pode se recusar a participar e isto não lhe causará nenhum prejuízo em seu atendimento no serviço, ou seja, sua recusa não interferirá no seu acompanhamento na UBS.

Se desejar participar, todos os seus dados pessoais, ou qualquer informação que possibilite que você seja identificada estarão sob sigilo, ou seja, me comprometo a não dizer quem você é. Não haverá nenhum tipo de compensação financeira caso aceite participar e nem despesas pessoais relacionadas a este estudo.

Você está protegida por diversas leis e comitês de ética sobre a pesquisa com humanos. Este projeto já foi avaliado e aprovado pelo Comitê de Ética da Faculdade de Medicina/USP - Rua Doutor Arnaldo, 251, $21^{\circ}$ andar, sala 36. Telefone: (11)3893-4401. E- 
mail: cep.fm@usp.br, e pelo Comitê de Ética da Secretaria Municipal de Saúde de São Paulo - Rua General Jardim, 36, 8ªndar. Telefone: (11)3397-2464.E-mail: smscep@gmail.com.

Você poderá entrar em contato com estes comitês de ética para dúvidas e para denúncias éticas. Também está disponibilizado neste Termo de Consentimento, o contato das pesquisadoras, para o esclarecimento de dúvidas sobre este Projeto de Pesquisa.

Comprometo-me a tratar de maneira ética e respeitosa as informações que venha a me fornecer. Depois de pronta, a pesquisa será divulgada em meios científicos.

Assim, caso aceite participar, por favor, assine este documento:

Eu e a minha orientadora também assinamos. E você receberá uma cópia deste. Obrigada!

$$
\begin{aligned}
& \text { Juliana Russo Antunes } \\
& \text { Mestranda } \\
& \text { CREFITO 3/13494-TO }
\end{aligned}
$$

\section{Fátima Côrrea Oliver \\ Orientadora \\ CREFITO 3/455-TO}

Contato:

E-mail: juliana.russo.antunes@usp.br, fcoliver@usp.br Departamento de Fisioterapia, Fonoaudiologia e Terapia Ocupacional - FMUSP Endereço: rua Cipotânea, 51, 1o. Andar, sala 3. Tel: 11 3091-7457, São Paulo - SP 
APÊNDICE G - Termo de Consentimento Livre e Esclarecido: profissionais

Olá, meu nome é Juliana Russo Antunes, com registro profissional CREFITO 3/13494-TO, e sou mestranda na Universidade de São Paulo pelo Programa de Mestrado Profissional Interunidades de Formação Interdisciplinar em Saúde A minha orientadora é profa. dra. Fátima Oliver, com registro profissional CREFITO 3/455-TO.

O tema da minha pesquisa é "O cuidado de mulheres em um serviço de Atenção Básica: problematização de uma experiência de trabalho interprofissional" e eu pretendo entrevistar profissionais e usuárias da UBS A" para entender como acontece o cuidado de mulheres e as necessidades encontradas, no intuito de propor melhorias para o serviço.

Você está sendo convidada a participar desta pesquisa porque acredito que tenha muito a contribuir nesta investigação. Além de você, 6 usuárias e 10 profissionais da UBS serão convidados a participarem, através de questões sobre seus percursos formativos, sua trajetória profissional e atuação na área da Saúde da Mulher. A entrevista será gravada e posteriormente transcrita; será conduzida de forma a criar um ambiente agradável para que se sinta confortável e que não lhe seja causado nenhum constrangimento. Caso não se sinta à vontade, poderá responder o que lhe for conveniente e ainda, interromper a sua participação. Você pode se recusar a participar e isto não lhe causará nenhum dano; sua recusa não interferirá na nossa relação profissional.

Havendo interesse em participar, todos os dados pessoais, ou qualquer informação que possibilite que você seja identificado estarão sob sigilo; não haverá nenhum tipo de compensação financeira caso aceite participar e você não terá despesas pessoais relacionadas a este estudo. Este projeto já foi avaliado e aprovado pelo Comitê de Ética da Faculdade de Medicina/USP - Rua Doutor Arnaldo, 251, $21^{\circ}$ andar, sala 36. Telefone: (11)3893-4401. Email: cep.fm@usp.br, e pelo Comitê de Ética da Secretaria Municipal de Saúde de São Paulo - Rua General Jardim, 36, $8^{\circ}$ andar. Telefone: (11)3397-2464.E-mail: smscep@gmail.com.

Você poderá entrar em contato com estes comitês de ética para dúvidas e para denúncias éticas. Está disponibilizado neste Termo de Consentimento, o contato das pesquisadoras, para o esclarecimento de dúvidas sobre este Projeto de Pesquisa.

Comprometo-me a tratar de maneira ética e respeitosa as informações que venha a me fornecer. Depois de pronta, a pesquisa será divulgada em meios científicos. 
Assim, caso aceite participar, por favor, assine este documento:

Eu e a minha orientadora também assinamos. E você receberá uma cópia deste. Obrigada!

Juliana Russo Antunes

Mestranda

CREFITO 3/13494-TO
Fátima Côrrea Oliver

Orientadora

CREFITO 3/455-TO

\section{Contato:}

E-mail: juliana.russo.antunes@usp.br, fcoliver@usp.br

Departamento de Fisioterapia, Fonoaudiologia e Terapia Ocupacional - FMUSP

Endereço: rua Cipotânea, 51, 1o. Andar, sala 3. Tel: 11 3091-7457, São Paulo - SP 
APÊNDICE H - Produto da pesquisa: "Grupo de mulheres na Atenção Básica - sistematização de uma experiência de cuidado"

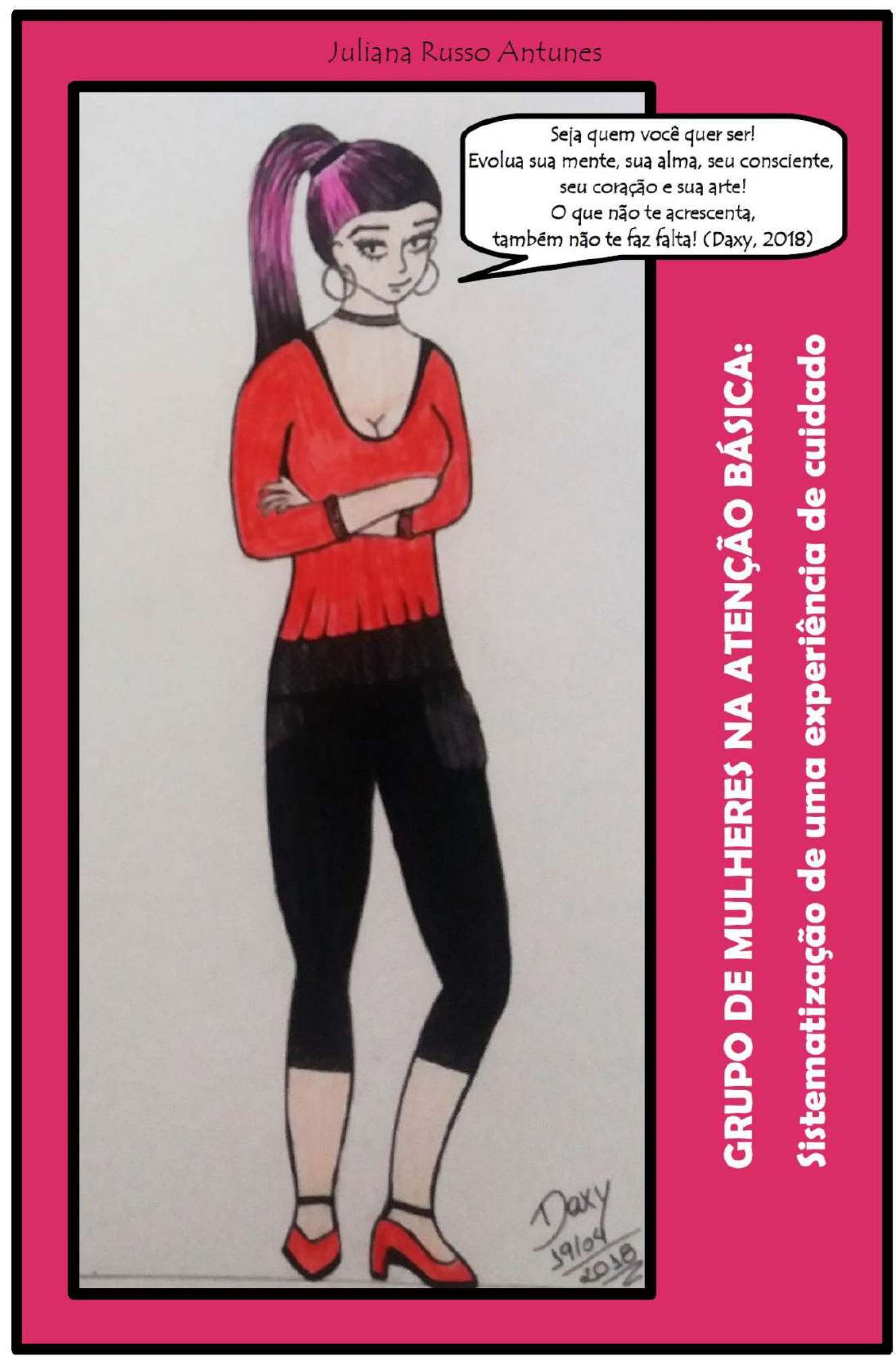




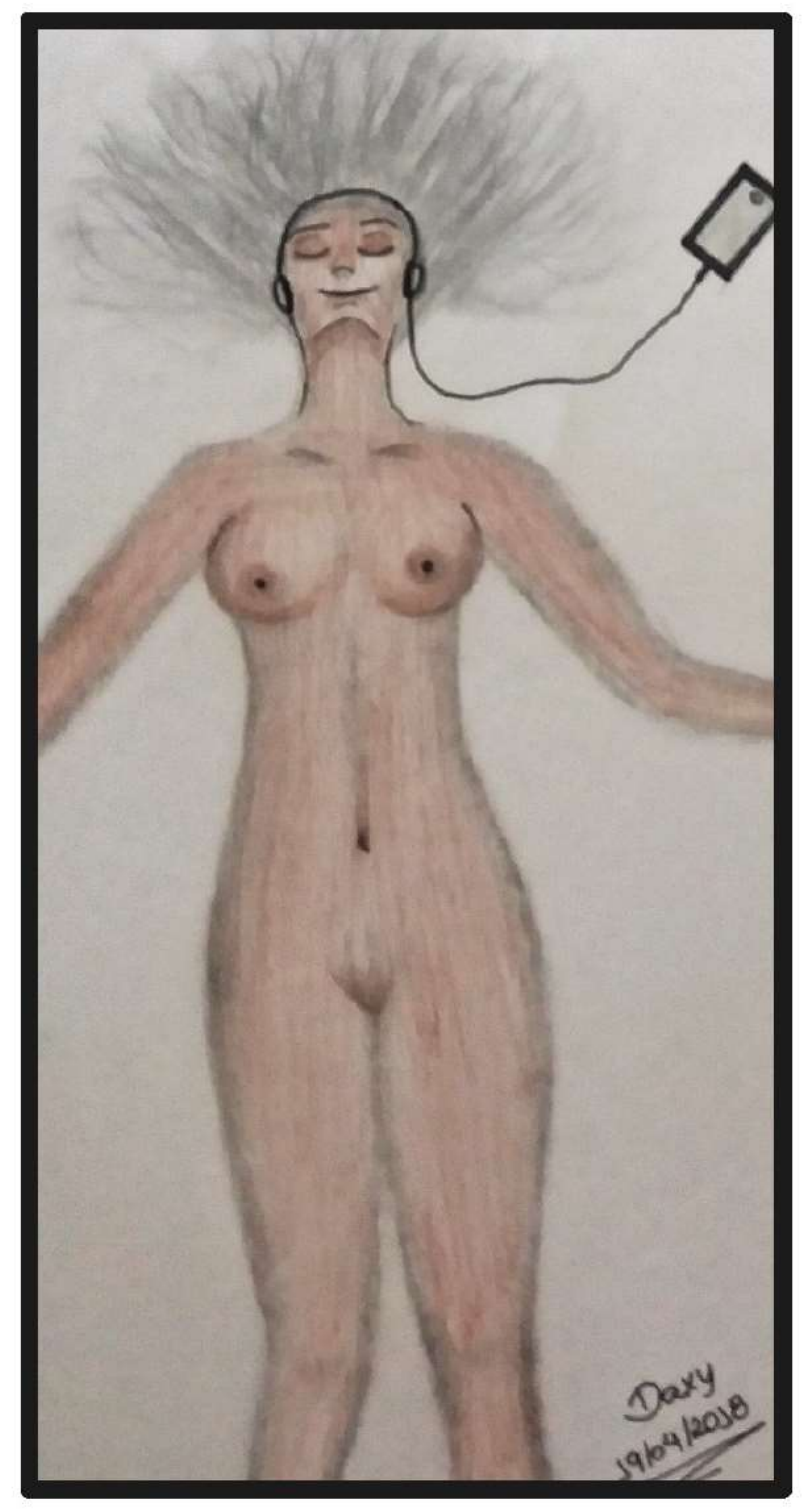

Às mulheres de antes, de agora e de depois Às mulheres que parem e que trabalham Às preguiçosas Às mulheres que riem e que choram Às mulheres que lutam Às mulheres que gozam Às mulheres bruxas Às Marias Às quem queimam Às quem idolatram Às mulheres que fui Às mulheres que sou Às mulheres que serei Àquelas que a querem ser Àquelas que sempre a foram Àqueles que as queimam, as idolatram, as moldam, as adoecem - as fortalecem. (Juliana Russo) 


\section{INIDICE}

APRESENTAÇÃ̃o

APORTE TEónico, ÉTICo, PoLítico

DISPOSITIVO GRUPAL

GÊNERO

(CONTRA A) MEDICALIZAÇÃO

NECESSIDADES DE SAÚDE

PESSOAS E SOFRIMENTOS

COMO FAZER UM GRUPO DE MULHERES

ORGANIZAÇÃO E REGISTRO DO PROCESSO DE TRABALHO 11

1 - Proposta de Projeto de Grupo 12

2 - Proposta de Lista de Presença 13

FUNCIONAMENTO 13

1 - Construindo a Roda 13

2 - Fazendo a Roda girar 14

3 - Para que a Roda continue girando 17

$\begin{array}{ll}\text { OPERANDO O PROCESSO GRUPAL } & 18\end{array}$

1 - Inventando a Roda 18

2 - Como a roda vai girando 19

SUGESTẼES DE LEITURA 23

REFERENCIAS 23

REFERÊNCIAS DAS “CAIXAS DE SUGESTÕES”

TEXTOS DE APOIO PARA UTILIZAR EM ATIVIDADES DO GRUPO 24

FICHA TÉCNICA 


\section{APRESENTAÇÃ̃}

Este Caderno foi desenvolvido a partir de uma pesquisa em que trabalhadoras e usuárias de um serviço de Atenção Básica ( $\mathrm{AB}$ ) foram entrevistadas*; só foi possível organizar esta sistematização do Grupo de Mulheres a partir da contribuição de cada uma destas pessoas. Elas foram convidadas a explanar sobre o cuidado de mulheres na $\mathrm{AB}$ e opinar sobre este Grupo, que é realizado em uma Unidade Básica de Saúde (UBS) em São Paulo - SP.

O primeiro ponto a ser ressaltado neste Caderno é: a constituição grupal é um processo longo, até mesmo de anos de trabalho, em que são necessárias constantes adequações e perseverança.

A segunda questão importante a ser destacada é a potência de um grupo para o cuidado de mulheres de um território e os sofrimentos vividos por elas, muitas vezes causados pela condição feminina de subjugação ao machismo, suas condições de vida e discriminações por sua raça/etnia, ou seja, experiências de sofrimento vivenciadas coletivamente e que podem ser cuidadas a partir de uma mesma perspectiva e ferramenta.

E a terceira questão de destaque seria a importância de um trabalho de equipe interdisciplinar para a coordenação deste grupo, em que a complexidade das mulheres são apresentadas e encontram olhares e estratégias diversas para contemplar as suas necessidades.

O Grupo de Mulheres foi proposto por três profissionais (fisioterapeuta, psicóloga e terapeuta ocupacional) de uma equipe interdisciplinar que trabalha em conjunto com outros profissionais de UBSs. Este grupo surgiu a partir de demanda por atendimentos individuais para cuidar de mulheres e as manifestações de suas diversas situações de sofrimento (adoecimentos). Porém, na relação terapêutica com estas mulheres, foi-se percebendo que suas experiências de sofrimento tinham conexão com suas histórias, condições de vida, e ainda, com questões de gênero, algo que os profissionais da $\mathrm{AB}$ pouco abordavam, devido à formação biologicista das profissões de saúde, da organização dos serviços de $\mathrm{AB}$ para contemplar prioridades e dos protocolos de práticas exigidos que levam o profissional a focar a em remissão de sintomas, havendo o risco de fazerem leituras "medicalizantes" dos sofrimentos apresentados pelas mulheres.

\footnotetext{
*Este Caderno é produto da pesquisa: "O cuidado de mulheres na Atenção Básica: problematização de uma experiência de trabalho interprofissional", e faz parte da Dissertação apresentada à Faculdade de Odontologia da Universidade de São Paulo, Programa Mestrado Profissional Interunidades de Formação Interdisciplinar em Saúde para a obtenção do título de Mestre em Ciências da Saúde, sob orientação da Profa. Dra. Fátima C. Oliver. Todas as participantes assinaram o Termo de Consentimento Livre e Esclarecido. O referido estudo foi avaliado e devidamente autorizado pelo Comitê de Ética em Pesquisa da Secretaria Municipal de Saúde do Município de São Paulo, com registro CAAE 57974216.0.3001.0086, parecer 2.026.744 (CEP/SMS), emitido em 22/04/2017. A pesquisa foi orientada pelos princípios éticos previstos na Resolução 196/96 do Conselho Nacional de Saúde.
} 


\section{aponte TEónico, ético, político DISPOSITIVO GRUPAL}

Nos dispositivos grupais da $\mathrm{AB}$, é importante que o trabalho seja direcionado no sentido de ampliação e qualificação das necessidades de saúde, bem como na construção coletiva de arranjos de cuidado, em que profissionais e usuárias são igualmente importantes. Assim, torna-se possível despertar e fortalecer os potenciais de fortalecimento das mulheres a partir do encontro entre elas, pois, é no coletivo que reside a possibilidade de transformação da sociedade e de fortalecimento individual. Por isso, enfatizamos a

potência do recurso grupal [...] O que é manifesto vem carregado de significações que, no contato com o outro, podem adquirir ainda novos significados, explicitando diferenças e semelhanças, traços culturais distintos, marcas das histórias e desejos (Samea, 2008 apud Rosa; Brançam, 2013, p.425).

Destacamos o conteúdo do "Caderno de Atenção Básica n.34 - Saúde Mental" (Brasil, 2013) e sua sessão sobre grupos de promoção de saúde mental na AB. Além de apresentar simplificadamente aportes teóricos sobre dispositivos grupais (grupos operativos), há dicas de como manejar um grupo, o que não seria interessante fazer e ainda, uma problematização dos grupos, ou melhor, "agrupamentos" (p.123) tradicionalmente realizados na AB que

costumam ser orientados pelas ações programáticas, modelo hegemônico de organização da ESF, centrado nos grupos prioritários de doenças/ agravos: grupo para pessoas com diabetes, hipertensão; atividade física; planejamento familiar; grupos de adesão medicamentosa, entre outros. Os objetivos são de gerar impactos nos indicadores na perspectiva da educação em saúde, comumente baseada num paradigma de transmissão do saber-fazer profissional. Se, por um lado, as propostas desses grupos organizam um modelo amplamente difundido, por outro, esgota-se a possibilidade de diálogo devido à manutenção da repetição do discurso, centrado no saber profissional (Brasil, 2013, p.121).

Ainda de acordo com o referido documento, o processo grupal,

desde que bem pensado em sua finalidade, estrutura e manejo, permite uma poderosa e rica troca de experiências e transformações subjetivas que não seria alcançável em um atendimento de tipo individualizado. Isto se deve exatamente à pluralidade de seus integrantes, à diversidade de trocas de conhecimentos e possíveis identificações que apenas um grupo torna possível (Brasil, 2013, p.121). 


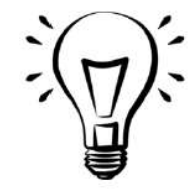

Enquanto profissional de saúde questione-se:

qual a finalidade dos "grupos" que realizo?

Porque os coordeno desta forma? É possível mudar o formato,

trabalhar os temas necessários e ainda assim suscitar a constituição grupal ${ }^{1}$.

\section{GÊNERO}

Diversos programas e políticas de saúde vêm sendo propostos à luz das questões de gênero desde a década de 90 , porém, a implementação deste pilar nas políticas, tem sido incipiente e até mesmo, inexistente. De acordo com o texto da Política Nacional de Atenção Integral à Saúde da Mulher (PNAISM) "mulheres e homens, em função da organização social das relações de gênero, também estão expostos a padrões distintos de sofrimento, adoecimento e morte" (Brasil, 2004, p.13). Os consequentes desequilíbrios entre os gêneros refletem-se não somente nos adoecimentos mas também nas leis, políticas e práticas sociais (como as práticas de saúde), identidades, atitudes e comportamentos das pessoas (Brasil, 2004, p.12).

A abordagem de gênero representa um referencial importante para melhor compreensão dos agravos à saúde da mulher e a construção de ações de prevenção de agravos e promoção de saúde, efetivas, além de propiciar o empoderamento da comunidade e das mulheres em particular, especialmente nos campos da violência doméstica, do planejamento familiar e da saúde mental. E, em relação ao planejamento familiar, a abordagem da sexualidade nos seus significados culturais e de gênero, bem como o entendimento do aspecto sociocultural da família, possibilita a ampliação da ação das equipes da SF [Estratégia de Saúde da Família] para além da distribuição de anticoncepcionais [...] que contemplem os vários objetivos do Plano Nacional de Atenção à Saúde da Mulher (Brasil, 2009, p.123)

Para aprofundar um pouco mais, vamos considerar que Gênero é um "dispositivo cultural constituído historicamente, que classifica e posiciona o mundo a partir da relação entre o que se entende como masculino e feminino. É um operador que cria sentido para as diferenças percebidas em nossos corpos e articula pessoas, emoções, práticas e coisas dentro de uma estrutura de poder. Os arranjos de gênero colocados em prática na sociedade exercem uma força sobre toda a nossa vida cotidiana" (Lins et al., 2016, p.10). 


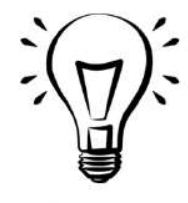

Questionando ditos populares, questionando "verdades": os ditos populares e as frases prontas são manifestações da cultura e do funcionamento social. Assim, é interessante

propor uma conversa com as mulheres do Grupo, e até mesmo, entre os profissionais, questionando sobre a reprodução de algumas das seguintes frases e o que cada um pensa

sobre seu conteúdo: menina é mais madura? Menino não chora? Rosa é cor de menina? Mulheres sempre querem casar?

Isso é coisa de homem? ${ }^{2}$

\section{(CONTRA A) MEDICALIZAÇÃO}

Consideramos que "medicalizar" significa a objetificação da vida cotidiana, conforme as normas sociais, e como exemplo de "doentificação", tem-se o tratamento da gravidez e da menopausa como doenças, a menstruação como distúrbio crônico e o parto como evento cirúrgico (Ehrenreich; English, 1973 apud Vieira, 2002, p.24), desta forma, a "reprodução é focalizada na mulher e na necessidade da sociedade controlar suas populações" (Vieira, 2002, p.21).

Nota-se esse movimento desde as décadas de 1930, 50 e 70, em que a saúde da mulher no Brasil era limitada às demandas da gravidez e do parto, e era organizada através do programa materno-infantil, que apresentava uma visão restrita sobre as mulheres de acordo com sua especificidade biológica e o papel social de mãe e doméstica, cuidadora do lar e da família, que lhes era (é) atribuído/imposto, o que sofreu diversas críticas do movimento feminista (Brasil, 2014).

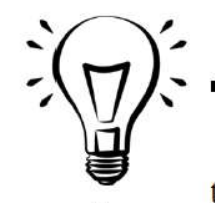

Você sabia que a Organização Mundial da Saúde compreende que até $15 \%$ de cesáreas do total de partos, sejam necessários de fato. No Brasil, esta taxa é de $55 \%$, colocando nosso país como líder mundial na realização desse rocedimento ${ }^{4}$

E como isso se expressa na sua experiência como profissional de saúde? Você também pode propor esta investigação para as mulheres participantes do Grupo ${ }^{3}$. 


\section{NECESSIDADES DE SAÚDE}

De acordo com discussões do campo da Saúde Coletiva, as necessidades de saúde são moduladas pelo capitalismo e suas instituições (Campos e Bataiero, 2007) e "da mesma forma que as necessidades são historicamente constituídas, também o são as respostas a elas" (Campos, 2009, p.144). Porém se não estivermos atentas às determinações de nosso processo de trabalho, "as necessidades colocadas em primeiro plano podem não ser as da população, mas sim a dos gestores, a dos programas, ou seja, $[\ldots]$ os interesses dos grupos que têm mais poder" (Campos, 2009, p.143).

Com o advento do capitalismo, as necessidades dos sujeitos vão sendo convertidas em necessidades por produtos. Os produtos ofertados para responder as necessidades de saúde são procedimentos, em sua maioria, consultas, e artigos da área hospitalar; assim, é reiterado aos sujeitos que a única possibilidade de respostas às suas necessidades de saúde são individualizadas e sob a forma de consultas médicas, exames e medicamentos (interesses das indústrias e corporações profissionais), e isto retroalimenta as suas necessidades - os sujeitos passam a necessitar somente daquilo que é ofertado (Campos e Bataiero, 2007).

Sendo assim, considerando que o Sistema Único de Saúde (SUS) é um sistema público e universal, suas práticas devem ser direcionadas a marcadores epidemiológicos, mas também, sociais, porém, vemos que majoritariamente são interesses de mercado que regem a implementação de serviços e políticas de saúde. De forma geral, todos os marcadores sociais da diferença: gênero, classe, raça/etnia, geração, operam de maneira interseccionada tanto como potenciais de desgaste quanto como potenciais de fortalecimento para a saúde da população; desta forma, para além dos procedimentos em saúde, o profissional deve acionar recursos de conscientização das condições de vida e mobilização social para efetivamente operar práticas que incidam sobre o perfil epidemiológico das populações atendidas.

Vale destacar a importância de conhecer a história e o perfil da população do território para o qual se direcionam as práticas de saúde, desde número de pessoas por gênero e faixas etárias, condições de moradia e saneamento básico, equipamentos (presença do Estado), condições de trabalho e faixa salarial, etc. 


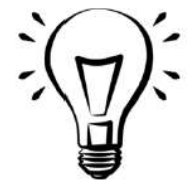

Como investigar necessidades ampliadas de saúde? Primeiramente, é importante compreender que as necessidades de saúde são muito mais amplas do que aquelas que os protocolos do processo de trabalha abarcam e respondem.

Assim, uma boa maneira de investigação é fazer perguntas abertas às mulheres sobre suas condições de vida e de reprodução social: moradia, trabalho, transporte, lazer, escolaridade, constituição familiar, relações, processos de adoecimento e recuperação, rede de apoio, serviços que utiliza, padrões de sono e alimentação, condições financeiras, etc.

\section{PESSOAS E SOFRIMENTOS}

Um sofrimento pode se manifestar se uma pessoa é privada de qualquer uma ou várias das dimensões do sujeito (Brasil, 2013, p.29-31), se a pessoa apresenta fatores de vulnerabilidade (discriminação por gênero, pobreza, cor da pele, etc.), se está em um momento de desestabilização (eventos de vida e seus significados), e da sua resiliência (temperamento e apoio social) (Brasil, 2013, p.92-93). Tudo isto deve ser considerado pelo profissional de saúde no momento de sua avaliação e na proposição dos cuidados.

Quanto às dimensões do sujeito, toda pessoa tem (Brasil, 2013, p.29-30):

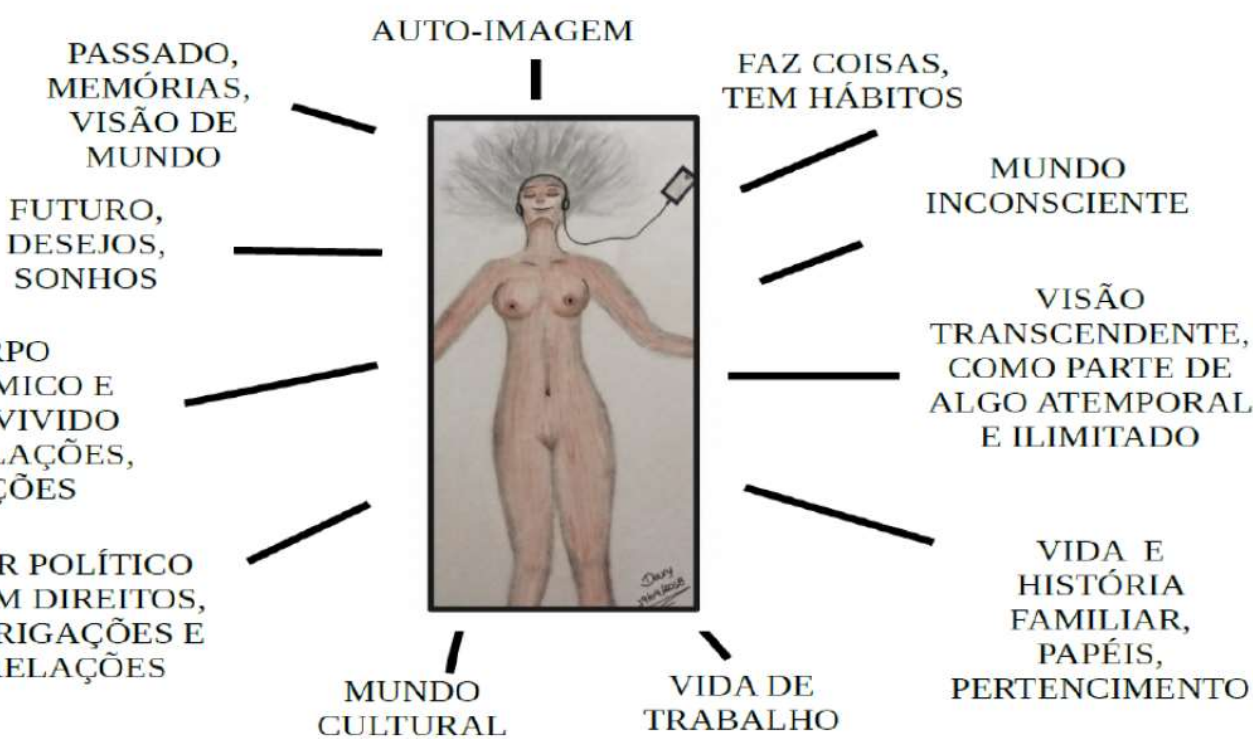


Mas de que sofrimento estamos falando?

Consideramos o sofrimento como uma "vivência da ameaça de ruptura da unidade/identidade da pessoa [...] torna-se fundamental para o profissional da $\mathrm{AB}$ manter-se atento às diversas dimensões do sujeito que se apresenta a sua frente" (Brasil, 2013, p. 32).

Tristeza, desânimo, perda do prazer de viver, irritabilidade, dificuldade de concentração, ansiedade e medo (às vezes na forma de crises) são queixas comuns dos usuários na $\mathrm{AB}$, que costumam estar associadas entre si e ainda a outras queixas: mudança no sono e apetite, dores, cansaço, palpitações, tontura ou mesmo alterações gástricas e intestinais (Goldberg, 2005 apud Brasil, 2013, p. 90-91). São queixas denominadas como sofrimentos comuns e reconhecidas como sintomas depressivos (tristeza/desânimo), ansiosos e de somatização (sintomas físicos sem explicação médica) (Brasil, 2013, p. 90-91). Há também outras situações de sofrimento que implicam usuários de álcool e outras drogas e ainda, pessoas com sofrimentos graves e persistentes, como as psicoses. Porém, todas estas pessoas apresentam situações de sofrimento que impactam diretamente em sua produção de vida, assim, independente do diagnóstico, devem receber escuta e cuidados.

Estas situações de sofrimentos comuns são as principais queixas apresentadas pelas mulheres na $\mathrm{AB}$, e mesmo com sintomas parecidos, as histórias de vida e rupturas são muito distintas, porém com uma grande questão em comum: gênero.

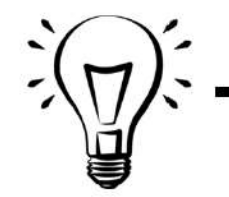

É importante fazermos uma ressalva sobre o uso de diagnósticos. Não quer dizer que devemos abrir mão de usar diagnósticos, bem como o acesso a direitos e recursos que eles propiciam.

Porém, é muito comum utilizarmos os diagnósticos de maneira pouco aprofundada, reforçando para as mulheres que a única solução para as situações de sofrimento são as medicações e as consultas médicas. Nem sempre um processo de luto quer dizer depressão, assim como situações da vida cotidiana podem gerar ansiedade, e até mesmo, certa intensidade de sensações, o que não denota um transtorno. Estas palavras, muitas vezes dadas sem explicação, causam grande impacto para as usuárias dos serviços de saúde,

e podem até mesmo dificultar os processos de recuperação de saúde.

Diagnósticos existem para serem utilizados, mas devemos considerar o caráter TEMPORÁRIO da maioria deles e trabalhar isto com nossos colegas e também com as mulheres que atendemos. É interessante discutir com as mulheres do Grupo sobre os diagnósticos que receberam e reforçar o caráter transitório da maioria dos adoecimentos; questionar sobre as sensações nas situações de dificuldades, e como podemos lidar, para além de usar medicações, etc. 


\section{COMO FAZER UM GRUPO IDE MULHERES}

\section{ORGANIZAÇÃO E REGISTRO DO PROCESSO DE TRABALHO}

Para fazer um Grupo de Mulheres, é necessário ter usuárias do serviço de saúde que concordem em participar dos encontros. Uma vez determinado o perfil do Grupo, das participantes e quando será realizado, conforme explicitado a seguir, as profissionais precisam combinar no serviço um Fluxo para a chegada das mulheres no Grupo: pode ser através de um cartaz, por convites, discussão de caso em equipe, a partir dos atendimentos, ou todas estas formas combinadas. Ressaltamos a importância de explicar claramente o funcionamento do Grupo para as profissionais e as mulheres e ainda, que a participação no Grupo seja parte de um projeto de cuidados direcionados a cada mulher. É importante tentar negociar com as mulheres que ao menos participem de um encontro do Grupo, pois comumente as pessoas se mostram resistentes a espaços grupais. Porém, caso a pessoa se recuse a participar de um grupo, isto deve ser respeitado e as profissionais devem continuar os cuidados em outros formatos de assistência.

É interessante manter uma pasta com os documentos de cada grupo, contendo o Projeto do Grupo, a lista de presença, folhas para registrar os encontros e outros materiais de uso e interesse. No item "2 - Como a roda vai girando" da sessão "Operando o processo Grupal" deste Caderno, apresentamos uma sequência de encontros, em que sugerimos uma maneira de registrar os encontros do Grupo. Organizar o Projeto auxilia a ter clareza da proposta, suas finalidades e facilita a divulgação, além de ser mais uma memória do processo de trabalho. Já a Lista de Presença, não trata apenas de controlar as presenças mas ter um registro destas, principalmente se se tratar de um grupo aberto, em que haverá circulação de muitas pessoas. Assim, a Lista auxilia no momento de evoluir prontuários, fazer busca ativa de usuárias, e também serve de registro do trabalho. A seguir, apresentamos sugestões para a documentação dos grupos. 
1 - Proposta de Projeto de Grupo:

NOME: Grupo de Mulheres

PROJETO DE GRUPO

DEMANDA: cuidar de mulheres e as manifestações de suas diversas situações de sofrimento (adoecimentos), comuns e severos. Mulheres jovens/adultas.

OBJETIVO: cuidar desta demanda muito recorrente, aprofundar a compreensão no sentido de apreender as reais necessidades de saúde, trabalhar coletivamente para mudança do perfil epidemiológico apresentado e das condições de vida.

PERFIL: os sofrimentos manifestados pelas mulheres têm em seu cerne: questões de gênero, violência contra a mulher, violência racial, vulnerabilidade social, a vida na periferia metropolitana, dificuldades com filhos e família, vulnerabilidade social, trabalhos opressores e desgastantes.

PILARES ÉTICO-POLÍTICOS: SUS e problematização de seu funcionamento, contra a medicalização da vida e do corpo feminino, questionamento do machismo e das condições de vida, problematização das normalidades e das questões de gênero, práticas emancipatórias, ampliação do cuidado, rede de suporte.

PROPOSTA DE AVALIAÇÃO: regularmente entre a coordenação e anualmente com as participantes do Grupo no momento; registrar presenças e evoluir um breve histórico nos prontuários semestralmente.

PROFISSIONAIS RESPONSÁVEIS: fisioterapeuta (nome), psicóloga (nome) e terapeuta ocupacional (nome) do NASF .

PERÍODO E LOCAL: encontros quinzenais (toda $1^{\mathrm{a}}$ e $3^{\mathrm{a}}$ sexta-feira/mês), com 2 horas de duração (das $10 \mathrm{~h}$ às $12 \mathrm{~h}$ )

FUNCIONAMENTO: grupo aberto, com possibilidade constante de chegada de novas participantes. Qualquer profissional pode encaminhar mulheres ao Grupo, mas solicitamos que sejamos avisadas, e quando possível, que discutamos em conjunto sobre os cuidados de cada mulher e agendamos acolhimento individual com uma das coordenadoras. 
2 - Proposta de Lista de Presença:

\begin{tabular}{|l|l|l|l|l|}
\hline LISTA DE PRESENÇA: __ SEMESTRE DE \\
GRUPO: \\
RESPONSÁVEIS: \\
HORÁRIO: \\
DIA: \\
LOCAL:
\end{tabular}

\section{FUNCIONAMENTO}

1 - Construindo a Roda:

Uma das formas de organizar a periodicidade de um Grupo de Mulheres é através de encontros quinzenais, com 2 horas de duração. Os encontros quinzenais são mais facilmente inseridos nas atividades cotidianas de trabalho remunerado, trabalho doméstico e cuidados dos filhos. Desta forma, pode-se optar por um encontro mais longo, com 2 horas, para possibilitar o cuidado das questões que se apresentam e ainda das chegadas constantes de novas integrantes.

O perfil aberto do grupo provou ser mais adequado para as necessidades das mulheres, que podem sair e retornar quando desejam e podem. Este arranjo possibilita diversas composições de participação no espaço: fixo (por um determinado tempo), mais flutuante ou até mesmo pontual (uma vez).

Destaca-se a importância de iniciar o encontro com a "Apresentação" dos sujeitos que compõem a roda, da proposta do Grupo e sua condição de grupo aberto, convidando as participantes antigas a se manifestarem, e recepção das novas integrantes. É necessário pactuar e reforçar constantemente o contrato de sigilo com as participantes, bem como o 
respeito mútuo, pois "saber quem somos e a que viemos é o primeiro passo para um encontro honesto e, de fato construtivo" (Godoy et al., 2014, p.17). Outra pactuação necessária é o tempo limite de espera para a chegada das participantes com as já presentes, inclusive para garantir que o encontro seja com mais de uma pessoa, e, caso apenas uma pessoa compareça, deve-se consultá-la sobre a condição de manutenção ou não do encontro e de que maneira ele poderia acontecer.

Antes de iniciar esta primeira atividade de "Apresentação", é necessário dispor o espaço em roda, conforme as possibilidades de dimensões do local e disponibilidade de assentos, contando com a ajuda das pessoas já presentes; no final do encontro, deve-se organizar o espaço conforme encontrado. A roda é essencial para enxergar a todas, em que o direcionamento ao centro, que está igualmente distante das pessoas, faz lembrar da partilha do objetivo e a mesma importância entre os pares (Godoy et al., 2014).

Algumas estratégias podem garantir certa organização e registro histórico do Grupo: lista de presença que possibilita a busca ativa de participantes que vieram a faltar e avaliação do impacto da proposta; calendário com as datas dos encontros do ano para facilitar a programação quinzenal e para que cada participante tenha autonomia em gerenciar suas faltas e retornos; cronograma coletivamente elaborado com propostas de atividades que só é possível de ser seguido quando há um corpo de participantes com certa frequência e ainda, se garantido espaço de recepção das novas integrantes e flexibilidade para atividades mais coerentes com o momento. Quando há somente participantes novas, o momento de "Apresentação" deve ser o foco do encontro, em que será necessário ser mais propositivo e improvisar atividades, respeitando este momento mais "reservado" de quem chega pela primeira vez.

É importante ofertar um horário de acolhimento individual para as novas mulheres com pessoas da coordenação, preferencialmente antes de seu ingresso no Grupo, para que as participantes se sintam mais seguras em chegar ao espaço e ainda, para que seja garantida a apresentação da proposta e esclarecimento sobre o funcionamento do Grupo.

\section{2 - Fazendo a Roda girar:}

Após esta primeira atividade de "Apresentação" (este espaço, estas pessoas), é o momento de acontecerem as outras "Atividades" do encontro, que podem ser escolhidas de duas maneiras: propostas pela coordenação e direcionadas ao cuidado de determinadas situações; propostas pelas próprias participantes, de acordo com repertórios que possuam e 
experiências prévias neste ou em outros grupos. Qualquer que seja a proposta ou a maneira de propô-la, que se dê em ato ou previamente, sempre garantir a negociação coletiva.

O papel da coordenação vai desde a garantia de quesitos materiais para a realização do grupo, como espaço, cadeiras, convites e divulgação, até a tarefa mais complexa de mediação. Mediar um grupo não se trata apenas de fomentar o encontro dos sujeitos, mas, cuidar deste encontro e de cada mulher individualmente; implica fazer leituras constantes das manifestações das participantes; proposições de atividades que acolham estas necessidades; observação atenta dos gestos, expressão corporal e desejos; enaltecimento das questões apresentadas individualmente para uma elaboração coletiva; cuidado para que as colocações de todas as participantes sejam acolhidas e ainda, respeitadas, sejam elas mais calorosas ou "apenas" com a presença. Além da organização de espaço e da mediação, a coordenação deve realizar avaliações constantes do processo grupal, das relações e das necessidades das mulheres.

Ressalta-se a importância de três profissionais na coordenação, uma vez que o cotidiano do trabalho na Atenção Básica é muito dinâmico e mutante, desta forma, facilita-se a garantia de participação de duas coordenadoras. Considera-se essencial que a coordenação em ato seja feita minimamente em dupla, pois mesmo com certo planejamento, acontecem imprevistos, o que exige capacidade de improviso e de criação com os recursos disponíveis, uma situação de grande complexidade (Godoy et al., 2014).

São importantes pilares de um grupo, a negociação permanente e a horizontalidade. Assim, as participantes podem se apresentar como co-terapeutas e corresponsáveis pelo Grupo, em que a resposta coletiva é forma privilegiada de direcionamento das questões e propostas (Godoy et al., 2014). As coordenadoras devem estar sempre disponíveis para os pedidos de "conversa individual" que venham a aparecer mesmo que seja agendada posteriormente. Entendemos a necessidade de respeitar estes pedidos, desde que sejam sempre reforçadas as potências do espaço grupal.

Um grupo funciona de acordo com o repertório técnico e pessoal de quem o coordena, assim como a história e as condições de vida das próprias participantes influi diretamente no perfil destes encontros; a condução deste Grupo de Mulheres foi realizada por uma terapeuta ocupacional, uma psicóloga e uma fisioterapeuta, desta forma, temos a configuração que é apresentada neste Caderno. As coordenadoras precisam estar sempre atentas e disponíveis para buscar alinhamentos teóricos e técnicos, de acordo com as necessidades que se apresentam no processo grupal. 
De acordo com a experiência do Grupo de Mulheres e considerando que este material foi produzido por uma terapeuta ocupacional, a seguir será apresentada uma análise mais aprofundada sobre o elemento "Atividades" em que

as atividades indicam campos da produção cultural, compreendendo um conjunto de hábitos, técnicas, instrumentos, materiais, formas socialmente estabelecidas de fazer e conhecimentos historicamente constituídos. É nesse sentido que podemos falar da atividade de pintura, de dança, de marcenaria, de ensino, de pesquisa, de jogos e brincadeiras etc. Já a ação designa um ato único, irreversível e singular que expressa o agente (Arendt, 2000 apud Lima et al., 2013, p.250-251).

As Atividades do Grupo de Mulheres podem ser apresentadas da seguinte forma:

- Atividades de ensinar-aprender, em que as habilidades de cada uma são valorizadas e as próprias participantes experimentam serem coordenadoras neste processo de ensinar o que sabem (exemplos: desenho, pintura, crochê, biscuit);

- Atividades de discussões temáticas, que precisam ser escolhidas previamente (exemplos: saúde reprodutiva e sexualidade; sofrimentos psíquicos e psicotrópicos; Lei Maria da Penha; violência de gênero; relacionamentos abusivos; direitos humanos)

- Atividades de rodas de conversa abertas, baseadas nas manifestações que emergem em um determinado encontro de acordo com as questões individuais apresentadas, sua problematização e reflexão coletiva;

- Atividades dirigidas pela coordenação, que implicam um repertório de vivências (experiências estéticas, por exemplo), ou um saber técnico como algumas modalidades de Práticas Integrativas e Corporais em Saúde - PICS (exemplos: massagem, meditação, exercícios para o assoalho pélvico, danças circulares, fitoterapia, confecção de mandalas).

Pode haver também a proposição de Atividades já realizadas em outro momento, porém, cada encontro é um encontro diferente do outro, se considerarmos que existe uma transformação das pessoas pela/da atividade. É importante nos percebermos diferentes na relação com determinado fazer, a partir de uma investigação e transformação da relação com este fazer, pois nos processos de sofrimento psíquico e adoecimentos é muito comum o rompimento do cotidiano ocupacional, desde as atividades necessárias e obrigatórias (trabalho, escola, cuidados casa e da família) e principalmente, das atividades criativas (cursos, artes, atividades corporais, sexo) e de auto-cuidado (higiene, estética, alimentação).

Outro destaque está em incentivar que as Atividades experimentadas no Grupo sejam utilizadas pelas mulheres quando estão sozinhas, angustiadas, tristes, com dificuldades, se configurando como instrumento de extensão da continência do espaço 
grupal e também como mecanismo de cuidado de si mesmas, bem como, investigar o perfil ocupacional destas mulheres, para além das atividades laborais e de cuidados com a casa e a família, e instigar a realização de atividades de interesse outrora realizadas.

Em seguida à realização das Atividades, é importante conduzir um momento de compartilhamento das experiências.

Ao propor atividades devemos considerar que elas têm funções e efeitos que são se resumem a serem disparadoras de discussões e elaborações; as pessoas se transformam também no feitio das atividades e nem sempre serão transformações tangíveis à expressão da fala. $\mathrm{O}$ feitio de atividades possibilita ressignificação de experiências, resgate de memórias afetivas e também da potência criativa, bem como experimentação de pequenos prazeres e reconhecimento de habilidades. Por isso a importância de proposições e análise de Atividades a partir dos encontros com os sujeitos, em que para além da "atividade em si", devemos estar atentas "ao movimento criativo onde quer que ele apareça" (Lima, 2004, p.47) pois tão importante quanto a realização de uma Atividade, incluída social, cultural e historicamente, é a "forma singular de fazer [...] quando um sujeito se faz presente em ato" (Lima et al., 2013, p.251).

Por fim, ao final de cada encontro, cabe realizar um planejamento do próximo encontro, seja para a sugestão e organização de uma Atividade ou mesmo para decidir se as Atividades ficarão a cargo das coordenadoras planejarem.

Destaca-se a importância de não realizar prescrição de alta, em que se trabalha no sentido da autonomia das mulheres para irem e retornarem quando desejarem ou necessitarem. Vale acrescentar que é importante uma atenção para as ausências, avaliando quando é expressão de autonomia ou quando é expressão de certa paralisia, e fazer um acompanhamento desta questão.

3 - Para que a Roda continue girando:

Algumas estratégias podem ser criadas para facilitar a participação das mulheres e ainda a manutenção do Grupo. Uma delas é a possibilidade de que as mulheres tragam os seus filhos para o espaço.

Outra estratégia é o respeito às idas e vindas e tempos de permanência possível no encontro (pressa, atrasos, sair para fumar, ficar só olhando, sair mais cedo). Compreendemos que participar do Grupo não implica apenas se colocar e fazer as Atividades propostas, apesar de ser necessário tentar negociar que a pessoa ao menos tente realizar determinada Atividade; 
somente o se dispor a vir já é um processo de grande importância, e com o tempo, as pessoas se sentem mais à vontade para estarem em roda e se colocarem.

É recomendado que anualmente (ou outra periodicidade desejada), seja realizada uma avaliação do Grupo junto com as participantes, sobre o funcionamento, dificuldades e potencialidades do espaço grupal, bem como a colaboração do Grupo nos processos individuais.

Para além da divulgação interna, algo a ser constantemente reforçado, vale divulgar o Grupo de Mulheres nos fóruns de trabalhadores e em outros serviços de saúde e de outros setores, assim, possibilita-se que o Grupo se torne um espaço de contra-referência das mulheres que fazem acompanhamento em outros serviços para além da UBS, dando uma continuidade nos processos terapêuticos que já realizavam.

Por fim, tentar manter os encontros do Grupo de Mulheres no mesmo período e dia da semana ao menos durante um ano, para facilitar o retorno de mulheres que foram participantes e a divulgação do espaço.

\section{OPERANDO O PROCESSO GRUPAL}

Para ilustrar a sistematização apresentada, a seguir um breve relato da História do Grupo de Mulheres e posteriormente, apresentaremos a descrição de uma pequena sequência de encontros realizados no ano de 2017.

1 - Inventando a Roda - História do Grupo de Mulheres:

Considerando a demanda de cuidar de mulheres e as manifestações de suas diversas situações de sofrimento (adoecimentos), comuns e severos, a pesquisadora, sendo terapeuta ocupacional desta equipe de NASF A, juntamente a psicóloga e uma das físioterapeutas, propuseram em maio/2014 um "Grupo de Saúde Mental” somente para mulheres.

Este espaço de encontro inicialmente seria: fechado - composto pelas mulheres já atendidas pelas profissionais; com frequência quinzenal - às sextas-feiras, com duas horas de duração; e as novas usuárias seriam convidadas após discussão de PTS na equipe ampliada NASF e ESF, e só seriam incluídas em dias determinados previamente. Após o início dos encontros, a proposta foi remodelada a partir do pequeno número de participantes: o grupo tornou-se aberto, com possibilidade de entrada de novas participantes em qualquer encontro. Algumas mulheres manifestaram incômodo com "Grupo de Saúde Mental", por não se identificarem como "loucas", ao que este nome remetia; assim, o grupo foi batizado como 
"Grupo de Mulheres". Entre 2015 e 2017, o Grupo foi realizado no Centro de Referência Assistência Social (CRAS), na sala do NASF na UBS e no CRAS novamente.

Comparando com os outros anos, em 2017 o Grupo recebeu menos participantes, porém, houve mulheres que participaram durante todo o ano, de maneira mais fixa, havendo encontros em que só estavam duas participantes; houve retorno de participantes antigas, sendo que uma delas traz os filhos por não ter com quem deixá-los; enfim, mulheres com seus diversos perfis de participação (fixo, flutuante, pontual).

2 - Como a roda vai girando - sequência de 4 encontros do Grupo de Mulheres

A seguir estarão descritos 4 encontros do Grupo, realizados em 2017. Em negrito estão palavras-chave que simbolizam as operações da sistematização deste Grupo, acima explicitadas. Utilizaremos códigos para manter sigilo e ainda assim, designar os diferentes sujeitos envolvidos, em que as coordenadoras são: C1 (pesquisadora), C2 e C3; todas as outras letras maiúsculas empregadas simbolizam mulheres participantes do Grupo e esta codificação se mantém ao longo dos 4 encontros descritos.

- Encontro do dia 07/07/17 (primeira sexta-feira do mês)

Local: CRAS

Horário: $9 \mathrm{~h} 30$ - 11h 10

Coordenadoras: $\mathrm{C} 1$ e $\mathrm{C} 2$ (C3 de Férias)

Participantes: 5 (2 participantes novas: M. e S. e 3 participantes antigas: A., Ad. e N.)

Atividades desenvolvidas: Organização do espaço em roda, Apresentação, Roda de Conversa Aberta, Dança Circular.

Descrição do encontro: N. e A. chegaram cedo e no CRAS não souberam informá-las sobre o Grupo e o local, mesmo já tendo sido acordado com o gerente. O prédio tem 2 andares, ambos com saídas para a rua, então, elas ficaram esperando no térreo, na recepção por um tempo, até que decidiram ir encontrar as coordenadoras na UBS; depois, foram juntas C1, N. e A. que arrumaram a sala, com as cadeiras em roda. $\mathrm{C} 2$ chegou depois, acompanhada de $\mathrm{M}$. que estava bastante irritada pois tinha ido ao CRAS onde não souberam informar sobre o Grupo, então ela retornou à UBS onde é informada que já estávamos no CRAS. Na saída da UBS, decidida à ir embora, M. encontrou a outra coordenadora, $\mathrm{C} 2$, que a acalmou e a convenceu a participar. E foi assim, sobre a irritação de M. e sua dificuldade em lidar com conflitos 
que começa a Roda de Conversa. Primeiramente foi feita a Apresentação do Grupo, e neste momento chegou outra nova participante, S. que se sentou na roda. A. ficou bem à vontade para falar da história do Grupo e N. fez um relato de sua melhora desde que começou a participar deste e do grupo de Práticas Integrativas na UBS. Em determinado momento, M. espirrou e comentou que houve um pequeno escape de xixi, ao que outras mulheres afirmam já terem the ocorrido o mesmo. Então, C2 sugere que façamos exercícios para incontinência urinária no próximo encontro, e assim, começaram a conversar sobre este assunto. As participantes não sabiam identificar em si mesmas a localização desta musculatura do assoalho pélvico e nem as suas possibilidades de movimentos voluntários, diziam não saber, portanto, controlar a saída de urina, e que a região estava "há muito tempo esquecida" (N.). As coordenadoras explicaram como seriam os exercícios; M. perguntou: "e o consolo?" e as outras mulheres: "o que é isso?"; o que gerou uma conversa sobre masturbação e ato sexual para além da penetração, e percebemos que N. ficou encabulada com a conversa. Foi combinado então ampliar a conversa do próximo encontro para além dos exercícios para o assoalho pélvico e falar de ciclo menstrual, libido e autocuidado. As mulheres concordaram com esta proposta e viriam com roupas confortáveis. O encontro foi finalizado com uma dança circular; Ad. chegou no fim do encontro "só para dar um 'oi'” e participou da dança circular.

- Encontro do dia 21/07/17 (terceira sexta-feira do mês)

Local: CRAS

Horário: $9 \mathrm{~h} 20$ - $11 \mathrm{~h} 00$

Coordenadoras: $\mathrm{C} 1$

Participantes: 5 (todas já participaram ao menos uma vez: S., N., C., An., A.)

Atividades desenvolvidas: Organização do espaço em roda, Apresentação, Discussão Temática.

Descrição do encontro: C2 precisou fazer um grupo sozinha na outra UBS apoiada por esta equipe Multiprofissional e C3 estava de férias, assim, C1 coordenou sozinha este encontro do Grupo. A outra fisioterapeuta desta equipe foi acionada para orientar uma sequência de exercícios para o assoalho pélvico e a partir disto, C1 organizou uma pequena apostila impressa para cada participante. $\mathrm{C} 1$ preparou também chás de camomila e erva cidreira, por compreender que iríam tratar de um tema cheio de tabus e até mesmo sofrimento, pensando em deixar o ambiente mais aconchegante. Porém, antes de começar com os 
exercícios, foi importante mostrar num Atlas de Anatomia figuras desta estrutura e em seguida, conversaram sobre o ciclo fértil feminino e menstruação. Duas mulheres manifestaram nem saber "como se pegava barriga", e ambas gestaram filhos. Foi utilizado um com um cartaz com um esquema da vagina que abordava as possibilidades de prazer e gozo desta região, e apesar de se mostrarem tímidas, as mulheres participaram ativamente. $\mathrm{N}$. trouxe um relato sobre sua experiência sexual com um homem, seu marido, e que foram poucas vezes que realizaram sexo, e que nunca sentiu prazer; logo no começo do casamento engravidou e quando seu filho tinha 8 meses, se divorciaram, e ela criou a criança, sozinha. An. contou sobre o abuso sexual sofrido, e neste momento reforçou o contrato de sigilo do Grupo; contou que teve relações sexuais consentidas com homens mas entendia "nunca ter gozado". Sobre a menstruação, conversaram sobre o estigma de sujeira, e N. trouxe que livros religiosos tratavam a menstruação desta forma; assim, o Grupo problematizou a escrita machista destes livros e de outras situações da vida da mulher. As mulheres conversaram também sobre chás para lidar com cólicas e TPM. Foi o primeiro encontro de S., que esteve participativa na discussão mas não colocou questões mais pessoais na roda. Não houve tempo para a realização dos exercícios para o assoalho pélvico, assim, esta Atividade foi deixada para o próximo encontro.

\section{- Encontro do dia 04/08/17 (primeira sexta-feira do mês)}

Local: CRAS

Horário: $9 \mathrm{~h} 35-10 \mathrm{~h} 40$

Coordenadoras: $\mathrm{C} 1$ e $\mathrm{C} 3$

Participantes: 6 (4 participantes antigas: S., C., An., F. e 2 participantes novas: Fi., M.)

Atividades desenvolvidas: Organização do espaço em roda, Apresentação, Prática Corporal e Dança Circular.

Descrição do encontro: $\mathrm{C} 2$ não pode comparecer; $\mathrm{C} 3$ retornou das férias. O Grupo recebeu as 2 novas participantes, mãe (M.) e filha ( $\mathrm{Fi}$, gestante), foi explicada a proposta do Grupo e deste encontro em que as novas participantes foram convidadas para colocarem as suas questões, e elas referem desejo de participarem do que tinha sido planejado; Fi estava no final da gestação e veio para acompanhar mãe, que jamais iria sozinha. Já estão na sala todas as participantes; An. que chegou mais tarde. F. estava retornando para o Grupo depois de um tempo afastada ( 8 meses) e trouxe os filhos de 7 e 4 anos, que ficaram brincando. $O$ chão da sala foi preparado com um colchonete, e C3 passou a orientar os exercícios para o 
assoalho pélvico; cada mulher estava deitada em um colchonete, e estiveram mais concentradas e caladas neste encontro. Referiram que é difícil perceber a musculatura pélvica; An. referiu grande dificuldade e solicitou ficar apenas deitada. Além dos exercícios, foi conversado sobre a necessidade de ingestão de água e não reter a urina, hábitos importantes para evitar a incontinência urinária e infecções. O encontro foi finalizado com uma Dança Circular; um dos filhos de F. aceitou o convite e participa da roda. Apesar de não ter participado do Grupo, C2 fez sugestão (por intermédio de C3 que a havia encontrado) de fazerem uma atividade de expressão estética - mandala de fios ("Olho de Deus") no próximo encontro e as mulheres concordaram em fazer esta atividade.

- Encontro do dia 18/08/17 (terceira sexta-feira do mês)

Local: CRAS

Horário: $9 \mathrm{~h} 39$ - 10h45

Coordenadoras: $\mathrm{C} 1$ e C3

Participantes: 6 (4 participantes antigas: N., An., A., Ad. e 2 participantes novas: P. e Pn.)

Atividades desenvolvidas: Organização do espaço em roda, Apresentação, Roda de Conversa Aberta.

Descrição do encontro: C2 não pode comparecer, assim, C1 e C3 coordenaram o Grupo. Após a Apresentação, as duas novas participantes referiram ter vindo ao Grupo por sintomas ansiosos/depressivos, ao que An. perguntou: “mas o que é ansiedade?”, e estas colocações dispararam uma conversa sobre ansiedade e depressão. Inicialmente, as coordenadoras falaram um pouco sobre a sintomatologia e as sensações e algumas mulheres trouxeram as próprias angústias, as experiências com medicações psicotrópicas e os espaços de cuidado que foram acessando. Também neste encontro, N. falou de suas participações nos grupos de Práticas Integrativas e neste Grupo de Mulheres e como isso a auxiliou, referindo estar muito bem. Ad. também trouxe a sua contribuição de como este Grupo a auxiliou, assim como sua participação em outros espaços, como um grupo de convivência para idosos, e ela contou da importância de não estar só nestes momentos de dificuldade e da importância da fé para a sua recuperação, e então, nos convidou para um café em sua casa e saiu apressada, "só vim para dar um 'oizinho"'. Assim, não foi realizada a atividade planejada, e com o aval das participantes, foi combinado de fazer a mandala de fios no próximo encontro. 


\section{SUGESTĨ ES DE LEITURA}

\section{REFERÊNCIAS}

Brasil. Política nacional de atenção integral à saúde da mulher: princípios e diretrizes.

Brasília: Ministério da Saúde; 2004.

Brasil. Cadernos de Atenção Básica, n. 27, série B - Diretrizes do NASF. Brasília: Ministério da Saúde; 2009.

***Brasil. Cadernos de Atenção Básica, n. 34 - NASF: Saúde Mental. Brasília: Ministério da Saúde; 2013.

Brasil. Cadernos de Atenção Básica, n. 39, vol. 1 - NASF: Ferramentas para a gestão e para o trabalho cotidiano. Brasília: Ministério da Saúde; 2014.

Campos CMS, Bataiero MO. Necessidades de saúde: uma análise da produção científica brasileira de 1990 a 2004. Interface - comunicação, saúde, educação. [Internet] 2007 Set-Dez [citado 15 de mai.2018]; 11(23):605-18. Disponível em:http://www.scielo.br/pdf/icse/v11n23/ a14v1123.pdf.

Campos CMS. Reconhecimento das necessidades de saúde dos adolescentes. In: Borges ALV, Fujimori E, organizadores. Enfermagem e a saúde do adolescente na atenção básica. Barueri: Manole; 2009. p.142-67.

Godoy A, Costa RM, Sant'anna M, Gomes BR. Método. In: Godoy, A, Gomes BR, Sant'anna M, Costa RM, organizadores. Revista do I Fórum Estadual de Redução de Danos do Estado de São Paulo. São Paulo: Córrego; 2014. p.16-9.

Lima EMFA. A análise de atividade e a construção do olhar do terapeuta ocupacional. Rev Terapia Ocupacional Univ São Paulo. 2004 Maio-Ago. 15(2): 42-8. doi: 10.11606/issn.22386149.v15i2p42-48. 
Lima EMFA, Okuma DG, Pastore MN. Atividade, ação, fazer e ocupação: a discussão dos termos na Terapia Ocupacional brasileira. Cad Terapia Ocupacional Univ Federal São Carlos. 2013. 21(2): 243-54. doi: 10.4322/cto.2013.026.

***Lins BA, Machado BF, Escoura M. Diferentes, não desiguais: a questão de gênero na escola. São Paulo: Editora Reviravolta; 2016. 144 p.

***Vieira EM. A medicalização do corpo feminino. 1 ${ }^{\text {a }}$.ed. Rio de Janeiro: Editora Fiocruz; 2002. 84 p.

***IMPERDÍVEIS!!!

\section{REFERÊNCIAS DAS “CAIXAS DE SUGESTÕES”}

惯:

1 Brasil. Cadernos de Atenção Básica, n. 34 - NASF: Saúde Mental. Brasília: Ministério da Saúde; 2013. p.122.

潧:

2 Lins BA, Machado BF, Escoura M. Diferentes, não desiguais: a questão de gênero na escola. São Paulo: Editora Reviravolta; 2016. p.15.

潧:

3 Declaração da OMS sobre taxas de cesáreas. 2015 Abr. [Internet] [citado 15 de mai.2018]. Disponível em: https://www.unasus.gov.br/noticia/declaracao-da-omssobre-taxas-de-cesareas.

\section{TEXTOS DE APOIO PARA UTILIZAR EM ATIVIDADES DO GRUPO}

Chimamanda Ngozi Adichie. Sejamos todos feministas. São Paulo: Companhia das Letras; 2015. 64 p.

Chimamanda Ngozi Adichie. Para educar crianças feministas - um manifesto. São Paulo: Companhia das Letras; 2017. 96 p. 
Duda Porto de Souza e Aryane Cararo. Extraordinárias mulheres que revolucionaram o Brasil. São Paulo: Seguinte; 2017. 208 p.

Elena Favili, Francesca Cavallo. Histórias de ninar para garotas rebeldes: cem fábulas sobre mulheres extraordinárias. Carla Bitelli, Flávia Yacubian, Zé Oliboni, tradutores. São Paulo: Vergara \& Riba Editoras; 2017. 220 p.

Carol Rosseti. Mulheres - retratos de respeito, amor-próprio, direitos e dignidade. Rio de Janeiro: Sextante; 2015. 160 p.

\section{FICHA TÉCNICA}

SOBRE A AUTORA

Juliana Russo Antunes é terapeuta ocupacional e trabalha no SUS, por escolha ética, estética e política. Na infância já protestava contra as exigências feitas a ela e às permissividades dadas ao irmão, e se incomodava quando the mandavam "sentar de pernas fechadas". Mas, somente em 2016, a partir das condições sociais e dos mergulhos teóricos provocados por sua pesquisa de mestrado, foi possível reconhecer-se feminista.

\section{SOBRE A ILUSTRADORA}

Daxane Alencar Gomes, também conhecida como Daxy, nasceu em São Paulo (no Brasil) em 1992. Formada cabeleireira e fã de cultura asiática, tem como hobbie assistir animes, ouvir Kpop e desenhar. Está sempre pesquisando novas técnicas, seja para cores ou traços, mantendo o alto-astral e o cabelo colorido como marcas registradas. 
ANEXO A - Parecer de aprovação pelo Comitê de Ética em Pesquisa da SMS/SP

SECRETARIA MUNICIPAL DA
SAÚDE DE SÃO PAULO -
SMSISP

\section{PARECER CONSUBSTANCIADO DO CEP}

Elaborado pela Instituição Coparticipante

DADOS DO PROJETO DE PESQUISA

Título da Pesquisa: O CUIDADO DE MULHERES EM UM SERVIÇO DE ATENÇÃO BÁSICA: PROBLEMATIZAÇÃO DE UMA EXPERIÉNCIA DE TRABALHO

Pesquisador: Fátima Corrêa Oliver

Área Temática:

Versão: 1

CAAE: 57974216.0 .3001 .0086

Instituição Proponente: Faculdade de Medicina da Universidade de São Paulo

Patrocinador Principal: Financiamento Próprio

DADOS DO PARECER

Número do Parecer: 2.026 .744

\section{Apresentação do Projeto:}

Projeto de pesquisa para obtenção do título de Mestra em Ciências, do Mestrado Profissional Interunidades de Formação Interdisciplinar em Saúde da Faculdade de Odontologia, Faculdade de Saúde Pública e Escola de Enfermagem da Universidade de São Paulo.

É uma pesquisa de abordagem qualitativa com metodologia de estudo de caso; a partir da realização de trabalho de campo com observação participante e de entrevistas com coordenadoras de NASF, trabalhadores da ESF. Serão 16 os sujeitos desta pesquisa: duas coordenadoras de NASF, duas profissionais do NASF, três mulheres usuárias da ESF e nove profissionais da ESF.

A análise dos dados será a de Análise de Conteúdo Temática.

\section{Objetivo da Pesquisa:}

Objetivo Geral

Descrever uma experiência de cuidado a mulheres numa UBS no âmbito da ESF em parceria com o NASF, sob o ponto de vista da integralidade do cuidado e as questões de gênero, de maneira a contribuir para o desenvolvimento da assistência no sentido da ampliação do cuidado às mulheres.

Objetivos Específicos

1. mapear as estratégias de cuidado ofertadas a mulheres nas UBS da região de saúde que contam

Endereço: Rua General Jardim, $36-1^{\circ}$ andar

Bairro: CENTRO

UF: SP Município: SAO PAULO

CEP: $\quad 01.223-010$

Telefone: (11)3397-2464

E-mail: smscep@gmail.com 


\section{USP - FACULDADE DE MEDICINA DA UNIVERSIDADE DE SÃO PAULO - FMUSP}

Continuação do Parecer: 1.954 .003

\section{Comentários e Considerações sobre a Pesquisa:}

Inclusão do centro coparticipante: Secretaria Municipal da Saúde do Estado de São Paulo

\section{Considerações sobre os Termos de apresentação obrigatória:}

O TCLE está de acordo com a resolução 466/12

\section{Recomendações:}

Não há

Conclusões ou Pendências e Lista de Inadequações:

Não há pendências

\section{Considerações Finais a critério do CEP:}

Este parecer foi elaborado baseado nos documentos abaixo relacionados:

\begin{tabular}{|c|c|c|c|c|}
\hline Tipo Documento & Arquivo & Postagem & Autor & Situação \\
\hline $\begin{array}{l}\text { Informações Básicas } \\
\text { do Projeto }\end{array}$ & $\begin{array}{l}\text { PB_INFORMAÇÓES_BÁSICAS_861156 } \\
\text { E1.pdf }\end{array}$ & $\begin{array}{c}07 / 02 / 2017 \\
14: 43: 30\end{array}$ & & Aceito \\
\hline Outros & cartaEmenda1_CEP.jpg & $\begin{array}{c}07 / 02 / 2017 \\
14: 40: 49\end{array}$ & Fátima Corrêa Oliver & Aceito \\
\hline Outros & autorizacaoSMS_coordnorte.jpg & $\begin{array}{c}06 / 02 / 2017 \\
12: 47: 39\end{array}$ & Fátima Corrêa Oliver & Aceito \\
\hline $\begin{array}{l}\text { TCLE / Termos de } \\
\text { Assentimento / } \\
\text { Justificativa de } \\
\text { Ausência } \\
\end{array}$ & JulianaRusso_TCLEcorrigido_CEP.doc & $\begin{array}{c}18 / 11 / 2016 \\
17: 50: 22\end{array}$ & Fátima Corrêa Oliver & Aceito \\
\hline $\begin{array}{l}\text { Recurso Anexado } \\
\text { pelo Pesquisador }\end{array}$ & $\begin{array}{l}\text { Oficio_CEP_FMUSP_Oliver_Russo_Cui } \\
\text { dado Mulheres.pdf }\end{array}$ & $\begin{array}{c}13 / 09 / 2016 \\
14: 51: 04\end{array}$ & Fátima Col & Aceito \\
\hline $\begin{array}{l}\text { TCLE / Termos de } \\
\text { Assentimento / } \\
\text { Justificativa de } \\
\text { Ausência }\end{array}$ & $\begin{array}{l}\text { TCLE_revisto_Oliver_Russo_CuidadoM } \\
\text { ulheres_set2016.pdf }\end{array}$ & $\begin{array}{c}13 / 09 / 2016 \\
14: 50: 31\end{array}$ & Fátima Corrêa Oliver & Aceito \\
\hline $\begin{array}{l}\text { Projeto Detalhado / } \\
\text { Brochura } \\
\text { Investigador }\end{array}$ & Projeto_CorrecaoParecer.doc & $\begin{array}{c}18 / 08 / 2016 \\
23: 24: 29\end{array}$ & Fátima Corrêa Oliver & Aceito \\
\hline Outros & folharostoFM.pdf & $\begin{array}{l}14 / 07 / 2016 \\
12: 53: 17\end{array}$ & Fátima Corrêa Oliver & Aceito \\
\hline Folha de Rosto & folharostoPBrasil.pdf & $\begin{array}{c}16 / 06 / 2016 \\
13: 35: 54\end{array}$ & Fátima Corrêa Oliver & Aceito \\
\hline Outros & aprovacaoUBS.jpg & $\begin{array}{c}14 / 06 / 2016 \\
19: 34: 21 \\
\end{array}$ & Fátima Corrêa Oliver & Aceito \\
\hline Cronograma & CRONOGRAMA.pdf & $\begin{array}{c}14 / 06 / 2016 \\
19: 29: 56 \\
\end{array}$ & Fátima Corrêa Oliver & Aceito \\
\hline
\end{tabular}

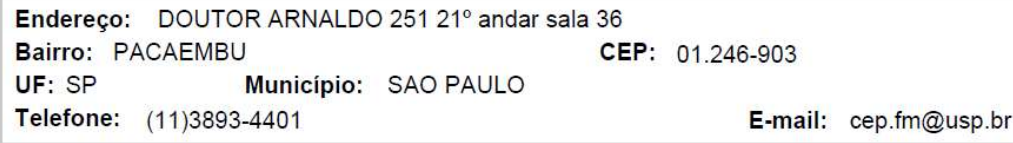




SECRETARIA MUNICIPAL DA
SAÚDE DE SÃO PAULO -
SMSISP

Continuação do Parecer: 2.026 .744

\section{Conclusões ou Pendências e Lista de Inadequações:}

Projeto liberado para iniciar coleta dos dados.

\section{Considerações Finais a critério do CEP:}

Para início da coleta dos dados, o pesquisador deverá se apresentar na mesma instância que autorizou a realização do estudo (Coordenadoria, Supervisão, SMS/Gab, etc).

Se o projeto prever aplicação de TCLE, todas as páginas do documento deverão ser rubricadas pelo pesquisador e pelo voluntário e a última página assinada por ambos, conforme Carta Circular no 003/2011 da CONEP/CNS.

Salientamos que o pesquisador deve desenvolver a pesquisa conforme delineada no protocolo aprovado. Eventuais modificações ou emendas ao protocolo devem ser apresentadas ao CEP de forma clara e sucinta, identificando a parte do protocolo a ser modificada e suas justificativas. Lembramos que esta modificação necessitará de aprovação ética do CEP antes de ser implementada.

De acordo com a Res. CNS 466/12, o pesquisador deve apresentar os relatórios parciais e final através da Plataforma Brasil, ícone Notificação. Uma cópia digital (CD/DVD) do projeto finalizado deverá ser enviada à instância que autorizou a realização do estudo, via correio ou entregue pessoalmente, logo que o mesmo estiver concluído.

Este parecer foi elaborado baseado nos documentos abaixo relacionados:

\begin{tabular}{|c|c|c|c|c|}
\hline Tipo Documento & Arquivo & Postagem & Autor & Situação \\
\hline Outros & cartaEmenda1_CEP.jpg & $\begin{array}{c}07 / 02 / 2017 \\
14: 40: 49\end{array}$ & Fátima Corrêa Oliver & Aceito \\
\hline $\begin{array}{l}\text { Informações Básicas } \\
\text { do Projeto }\end{array}$ & $\begin{array}{l}\text { PB_INFORMAÇÓES_BÁSICAS_861156 } \\
\text { E1.pdf }\end{array}$ & $\begin{array}{l}06 / 02 / 2017 \\
12: 49: 57\end{array}$ & & Aceito \\
\hline Outros & autorizacaoSMS_coordnorte.jpg & $\begin{array}{c}06 / 02 / 2017 \\
12: 47: 39\end{array}$ & Fátima Corrêa Oliver & Aceito \\
\hline $\begin{array}{l}\text { TCLE / Termos de } \\
\text { Assentimento / } \\
\text { Justificativa de } \\
\text { Ausência }\end{array}$ & JulianaRusso_TCLEcorrigido_CEP.doc & $\begin{array}{c}18 / 11 / 2016 \\
17: 50: 22\end{array}$ & Fátima Corrêa Oliver & Aceito \\
\hline $\begin{array}{l}\text { Recurso Anexado } \\
\text { pelo Pesquisador }\end{array}$ & $\begin{array}{l}\text { Oficio_CEP_FMUSP_Oliver_Russo_Cui } \\
\text { dado Mulheres.pdf }\end{array}$ & $\begin{array}{c}13 / 09 / 2016 \\
14: 51: 04\end{array}$ & Fátima Corrêa Oliver & Aceito \\
\hline $\begin{array}{l}\text { TCLE / Termos de } \\
\text { Assentimento / } \\
\text { Justificativa de }\end{array}$ & $\begin{array}{l}\text { TCLE_revisto_Oliver_Russo_CuidadoM } \\
\text { ulheres_set2016.pdf }\end{array}$ & $\begin{array}{c}13 / 09 / 2016 \\
14: 50: 31\end{array}$ & Fátima Corrêa Oliver & Aceito \\
\hline
\end{tabular}

Endereço: Rua General Jardim, $36-1^{\circ}$ andar Bairro: CENTRO

UF: SP Município: SAO PAULO

Telefone: (11)3397-2464

CEP: $\quad 01.223-010$ 


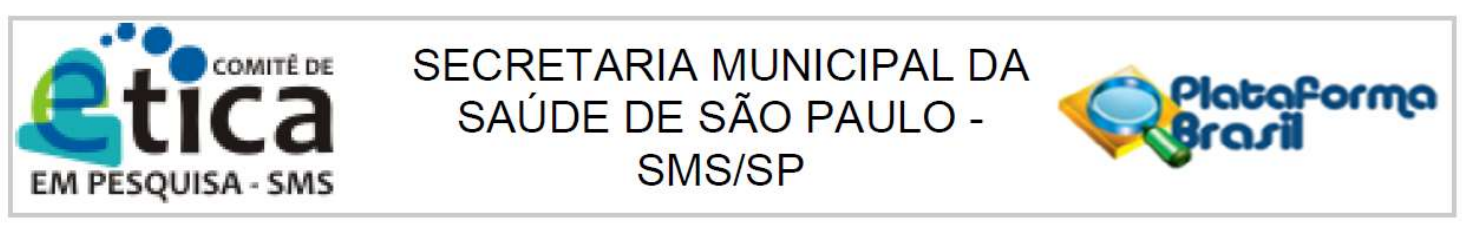

Continuação do Parecer: 2.026 .744

\begin{tabular}{|c|c|c|c|c|}
\hline Ausência & $\begin{array}{l}\text { TCLE_revisto_Oliver_Russo_CuidadoM } \\
\text { ulheres set2016.pdf }\end{array}$ & $\begin{array}{c}13 / 09 / 2016 \\
14: 50: 31 \\
\end{array}$ & Fátima Corrêa Oliver & Aceito \\
\hline $\begin{array}{l}\text { Projeto Detalhado / } \\
\text { Brochura } \\
\text { Investigador }\end{array}$ & Projeto_CorrecaoParecer.doc & $\begin{array}{c}18 / 08 / 2016 \\
23: 24: 29\end{array}$ & Fátima Corrêa Oliver & Aceito \\
\hline Outros & folharostoFM.pdf & $\begin{array}{c}14 / 07 / 2016 \\
12: 53: 17\end{array}$ & Fátima Corrêa Oliver & Aceito \\
\hline Folha de Rosto & folharostoPBrasil.pdf & $\begin{array}{c}16 / 06 / 2016 \\
13: 35: 54\end{array}$ & Fátima Corrêa Oliver & Aceito \\
\hline Outros & aprovacaoUBS.jpg & $\begin{array}{c}14 / 06 / 2016 \\
19: 34: 21 \\
\end{array}$ & Fátima Corrêa Oliver & Aceito \\
\hline Cronograma & CRONOGRAMA.pdf & $\begin{array}{c}14 / 06 / 2016 \\
19: 29: 56\end{array}$ & Fátima Corrêa Oliver & Aceito \\
\hline $\begin{array}{l}\text { TCLE / Termos de } \\
\text { Assentimento / } \\
\text { Justificativa de } \\
\text { Ausência }\end{array}$ & TCLE.pdf & $\begin{array}{c}14 / 06 / 2016 \\
19: 28: 23\end{array}$ & Fátima Corrêa Oliver & Aceito \\
\hline Orçamento & ORCAMENTO.pdf & $\begin{array}{l}14 / 06 / 2016 \\
19: 27: 47\end{array}$ & Fátima Corrêa Oliver & Aceito \\
\hline $\begin{array}{l}\text { Projeto Detalhado / } \\
\text { Brochura } \\
\text { Investigador }\end{array}$ & ProjetoPesquisa.pdf & $\begin{array}{l}14 / 06 / 2016 \\
19: 27: 09\end{array}$ & Fátima Corrêa Oliver & Aceito \\
\hline
\end{tabular}

Situação do Parecer:

Aprovado

Necessita Apreciação da CONEP:

Não

SAO PAULO, 22 de Abril de 2017

Assinado por:

SIMONE MONGELLI DE FANTINI

(Coordenador)

Endereço: Rua General Jardim, $36-1^{\circ}$ andar

Bairro: CENTRO

UF: SP

Município: SAO PAULO

CEP: $\quad 01.223-010$

Telefone: (11)3397-2464

E-mail: smscep@gmail.com 
ANEXO B - Parecer de aprovação pelo Comitê de Ética em Pesquisa da FMUSP

\section{USP - FACULDADE DE MEDICINA DA UNIVERSIDADE DE SÃO PAULO - FMUSP}

\section{PARECER CONSUBSTANCIADO DO CEP}

\section{DADOS DA EMENDA}

Título da Pesquisa: O CUIDADO DE MULHERES EM UM SERVIÇO DE ATENÇÃO BÁSICA: PROBLEMATIZAÇÃO DE UMA EXPERIENCIA DE TRABALHO

Pesquisador: Fátima Corrêa Oliver

Área Temática:

Versão: 5

CAAE: 57974216.0 .0000 .0065

Instituição Proponente: Faculdade de Medicina da Universidade de São Paulo

Patrocinador Principal: Financiamento Próprio

\section{DADOS DO PARECER}

Número do Parecer: 1.954 .003

\section{Apresentação do Projeto:}

Emenda para inclusão de um centro coparticipante.

\section{Objetivo da Pesquisa:}

Objetivo Primário:

Descrever uma experiência de cuidado a mulheres numa UBS no âmbito da ESF em parceria com o NASF, sob o ponto de vista da integralidade do cuidado e as questões de gênero, de maneira a contribuir para o desenvolvimento da assistência no sentido da ampliação do cuidado às mulheres.

\section{Avaliação dos Riscos e Benefícios:}

Riscos:

Não são previstos riscos à saúde. Durante as entrevistas e observação participante, o pesquisador procurará criar um ambiente favorável à participação dos sujeitos da pesquisa, procurando criar condições para que se expressem livremente e com a maior naturalidade possível.

Benefícios:

Contribuir para a avaliação e desenvolvimento de propostas assistenciais realizadas em grupo e por equipe interprofissional, de modo a favorecer o acesso e abordagem integral dos problemas vivenciados por mulheres no âmbito da Atenção Primária em Saúde

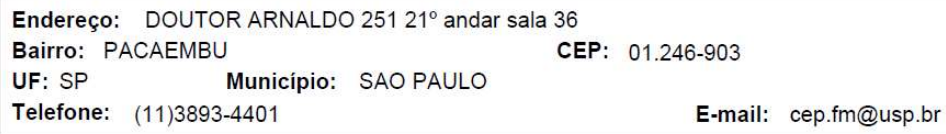




\section{USP - FACULDADE DE MEDICINA DA UNIVERSIDADE DE SÃO PAULO - FMUSP}

Continuação do Parecer: 1.954 .003

\section{Comentários e Considerações sobre a Pesquisa:}

Inclusão do centro coparticipante: Secretaria Municipal da Saúde do Estado de São Paulo

Considerações sobre os Termos de apresentação obrigatória:

O TCLE está de acordo com a resolução 466/12

\section{Recomendações:}

Não há

Conclusões ou Pendências e Lista de Inadequações:

Não há pendências

\section{Considerações Finais a critério do CEP:}

Este parecer foi elaborado baseado nos documentos abaixo relacionados:

\begin{tabular}{|c|c|c|c|c|}
\hline Tipo Documento & Arquivo & Postagem & Autor & Situação \\
\hline $\begin{array}{l}\text { Informações Básicas } \\
\text { do Projeto }\end{array}$ & $\begin{array}{l}\text { PB_INFORMAÇÓES_BÁSICAS_861156 } \\
\text { E1.pdf }\end{array}$ & $\begin{array}{c}07 / 02 / 2017 \\
14: 43: 30\end{array}$ & & Aceito \\
\hline Outros & cartaEmenda1_CEP.jpg & $\begin{array}{c}07 / 02 / 2017 \\
14: 40: 49 \\
\end{array}$ & Fátima Corrêa Oliver & Aceito \\
\hline Outros & autorizacaoSMS_coordnorte.jpg & $\begin{array}{c}06 / 02 / 2017 \\
12: 47: 39 \\
\end{array}$ & Fátima Corrêa Oliver & Aceito \\
\hline $\begin{array}{l}\text { TCLE / Termos de } \\
\text { Assentimento / } \\
\text { Justificativa de } \\
\text { Ausência }\end{array}$ & JulianaRusso_TCLEcorrigido_CEP.doc & $\begin{array}{c}18 / 11 / 2016 \\
17: 50: 22\end{array}$ & Fátima Corrêa Oliver & Aceito \\
\hline $\begin{array}{l}\text { Recurso Anexado } \\
\text { pelo Pesquisador }\end{array}$ & $\begin{array}{l}\text { Oficio_CEP_FMUSP_Oliver_Russo_Cui } \\
\text { dado Mulheres.pdf }\end{array}$ & $\begin{array}{c}13 / 09 / 2016 \\
14: 51: 04\end{array}$ & Fátima Corrêa Oliver & Aceito \\
\hline $\begin{array}{l}\text { TCLE / Termos de } \\
\text { Assentimento / } \\
\text { Justificativa de } \\
\text { Ausência }\end{array}$ & $\begin{array}{l}\text { TCLE_revisto_Oliver_Russo_CuidadoM } \\
\text { ulheres_set2016.pdf }\end{array}$ & $\begin{array}{c}13 / 09 / 2016 \\
14: 50: 31\end{array}$ & Fátima Corrêa Oliver & Aceito \\
\hline $\begin{array}{l}\text { Projeto Detalhado / } \\
\text { Brochura } \\
\text { Investigador }\end{array}$ & Projeto_CorrecaoParecer.doc & $\begin{array}{c}18 / 08 / 2016 \\
23: 24: 29\end{array}$ & Fátima Corrêa Oliver & Aceito \\
\hline Outros & folharostoFM.pdf & $\begin{array}{c}14 / 07 / 2016 \\
12: 53: 17 \\
\end{array}$ & Fátima Corrêa Oliver & Aceito \\
\hline Folha de Rosto & folharostoPBrasil.pdf & $\begin{array}{c}16 / 06 / 2016 \\
13: 35: 54 \\
\end{array}$ & Fátima Corrêa Oliver & Aceito \\
\hline Outros & aprovacaoUBS.jpg & $\begin{array}{c}14 / 06 / 2016 \\
19: 34: 21\end{array}$ & Fátima Corrêa Oliver & Aceito \\
\hline Cronograma & CRONOGRAMA.pdf & $\begin{array}{c}14 / 06 / 2016 \\
19: 29: 56 \\
\end{array}$ & Fátima Corrêa Oliver & Aceito \\
\hline
\end{tabular}

Endereço: DOUTOR ARNALDO $25121^{\circ}$ andar sala 36

Bairro: PACAEMBU

CEP: $01.246-903$

UF: SP

Município: SAO PAULO

Telefone: (11)3893-4401

E-mail: cep.fm@usp.br 


\section{USP - FACULDADE DE MEDICINA DA UNIVERSIDADE \\ DE SÃO PAULO - FMUSP}

Continuação do Parecer: 1.954 .003

\begin{tabular}{|l|l|c|l|c|}
\hline TCLE / Termos de & TCLE.pdf & $14 / 06 / 2016$ & Fátima Corrêa Oliver & Aceito \\
Assentimento / & & $19: 28: 23$ & & \\
Justificativa de & & & & \\
Ausência & & $14 / 06 / 2016$ & Fátima Corrêa Oliver & Aceito \\
\hline Orçamento & ORCAMENTO.pdf & $19: 27: 47$ & & \\
\hline Projeto Detalhado / & ProjetoPesquisa.pdf & $19: 27: 09$ & Fátima Corrêa Oliver & Aceito \\
Brochura & & & \\
lnvestiqador & & & \\
\hline
\end{tabular}

Situação do Parecer:

Aprovado

Necessita Apreciação da CONEP:

Não

SAO PAULO, 08 de Março de 2017

Assinado por:

Maria Aparecida Azevedo Koike Folgueira

(Coordenador)

Endereço: DOUTOR ARNALDO $25121^{\circ}$ andar sala 36

Bairro: PACAEMBU

CEP: $01.246-903$

UF: SP

Município: SAO PAULO

Telefone: (11)3893-4401

E-mail: cep.fm@usp.br 